VIVIANI OLIVASTRO BRESSANI

\title{
CARACTERIZAÇÃO DA RESPOSTA IMUNOLÓGICA CELULAR EM PACIENTES PORTADORES DE DERMATOFITOSES EXTENSAS CAUSADA POR
}

Trichophyton rubrum

Dissertação apresentada à Faculdade de Medicina da Universidade de São Paulo para obtenção do título de Mestre em Ciências

Programa: Dermatologia

Orientador: Prof. Dr. Dewton de Moraes Vasconcelos

São Paulo 


\section{Dados Internacionais de Catalogação na Publicação (CIP)}

Preparada pela Biblioteca da

Faculdade de Medicina da Universidade de São Paulo

Creprodução autorizada pelo autor

\section{Bressani, Viviani Olivastro}

Caracterização da resposta imunológica celular em pacientes portadores de dermatofitoses extensas causadas por Trichophyton rubrum / Viviani Olivastro Bressani. - São Paulo, 2011.

Dissertação (mestrado) - Faculdade de Medicina da Universidade de São Paulo.

Programa de Dermatologia.

Orientador: Dewton de Moraes Vasconcelos.

Descritores: 1.Dermatomicoses 2.Trichophyton rubrum 3.Citocinas 4.Linfócitos 5.Imunidade

USP/FM/DBD-290/11 


\section{Oração a Bezerra de Menezes}

$\mathcal{N}$ Nós te rogamos, Paí de infinita bondade e justiça, as graças de Jesus Cristo, através de BEZERRA $\mathcal{D E} \mathcal{M E N E Z E S ~ e ~}$ suas legióes de companheiros.

Que eles nos assistam, Senhor, consolando os aflitos, curando aqueles que tiverem suas provas e expiações a passar, esclarecendo aos que desejarem conhecer a verdade e assistindo a todos quantos apelarem ao teu infinito amor.

Jesus, divino portador da graça e da verdade, estende tuas mãos dadivosas em socorro daqueles que te reconhecem o despenseiro fiel e prudente; faze-o, divino Mestre, através de tuas legióes consoladoras, de teus santos espiritos, a fim de que a fé se eleve, a esperança aumente, a bondade se expanda e o amor triunfe sobre todas as coisas.

BEZERRA DE $\mathcal{M E N E Z E S , ~ a p o ́ s t o l o ~ d o ~ b e m ~ e ~ d a ~ p a z , ~}$ amigo dos humildes e dos enfermos, movimenta as tuas falanges amigas em benefício daqueles que sofrem, sejam dos males físicos ou espirituais. Santos espiritos, dignos obreiros do Senhor, derramem as graças e as curas sobre a humanidade sofredora, a 
fim de que as criaturas se tornem amigas da paz e do conhecimento, da harmonía e do perdão, semeando pelo mundo os divinos exemplos de JESUS CRISTO. 
o Resfriado escorre quando o corpo não chora.

$\mathcal{A}$ dor de garganta entope quando não é possivel comunicar as aflições.

O estômago arde quando as raivas não conseguem sair.

O diabetes invade quando a solidão dói.

O corpo engorda quando a insatisfação aperta.

$\mathcal{A}$ dor de cabeça deprime quando as dúvidas aumentam.

O coração desiste quando o sentído da vida parece terminar.

$\mathcal{A}$ alergía aparece quando o perfeccionismo fíca intolerável.

As unhas quebram quando as defesas ficam ameaçadas.

o peito aperta quando o orgutho escraviza.

O coração infarta quando chega a ingratidão.

A pressão sobe quando o medo aprisiona.

As neuroses paralisam quando a "criança interna" tiraniza.

$\mathcal{A}$ febre esquenta quando as defesas detonam as fronteiras da imunidade. 
Preste atenção!!!!

O plantio é lívre, a colheita, é obrigatória.... Preste atenção no que você está plantando, pois será a mesma coísa que irá colher!

Escolha ser feliz.

"Faça o que for necessárío para ser feliz. Mas não se esqueça que a felícidade é um sentimento simples, você pode encontrá-la e deixá-la ir embora por não perceber sua simplicidade" 


\section{Dedicatória}

Dedico este trabalho a Deus, aos Anjos de Luz, aos meus pais, irmãos, tia Célia e meu noivo por me apoiarem e me estimularem com palavras e exemplos de vida a cada etapa deste projeto. Sem vocês minha vida não vale de nada.

Ao Dr. Bezerra de Menezes, conhecido como o médico dos pobres, que com Luz, sua humildade, honestidade, respeito e amor a ciência e amor ao próximo, me ensinou que conseguimos chegar aos nossos objetivos com exímio amor, determinação, simplicidade, humildade, fé em Deus e muito respeito ao próximo.

Em especial a minha querida e amada avó Maria Antônia Braga dos Santos (In Memoriam), pelo carinho, pelos exemplos de vida, por incentivos, pelas alegrias, pelas palavras de sabedoria e pelo amor que sempre nos presenteaste. Amo-te muito. 


\section{Agradecimentos}

Primeiramente agradeço a Deus por estar presente e morar em meu coração, em cada passo da minha vida, pela oportunidade em me presentear e poder realizar mais um sonho de fazer Mestrado e poder ajudar tantas pessoas com este trabalho rico de amor e competência.

Agradeço a Deus, a Jesus, a Mestra Maria, por colocarem em minha caminhada Anjos de Luz que me guiaram com palavras, exemplos de vida para que eu nunca desistisse.

A meus pais Paulo Gilberto Bressani e Maria Regina dos Santos Bressani, pela educação que me deram, pelas orações, por acreditarem em mim e pelas orientações maravilhosas de como saber lidar com a vida, sem esquecer Deus, Jesus e Maria, aprendendo com humildade, simplicidade, equilíbrio, determinação, respeito, fé e muito amor. Obrigada por tudo!!!

Aos meus irmãos Paulo Henrique Bressani, Paulo Vinícius Bressani e Regiane Bressani por serem pessoas importantes em minha vida e que me ajudaram com palavras e amor em todos os momentos da minha vida.

Aos meus sobrinhos Raphael Santos Bressani, Gabriella Braga Bressani e Arthur de Oliveira Bressani por enriquecerem a minha vida de alegrias, aprendizados e muito amor.

À minha tia Célia Maria Braga dos Santos e à minha cunhada Andréa Correia de Oliveira pelas orações, por acreditarem em mim, por palavras de incentivo e por conselhos cheios de amor. 
Aos meus sogros Wagner Miguel Sartorelli e Dalva Maria Derrè Sartorelli por serem meus segundos pais e por me orientarem na caminhada da vida.

Ao meu noivo Amaury César Derrè Sartorelli por fazer parte da minha vida, por me trazer alegrias, por me orientar com palavras de sabedoria e amor, por saber lidar comigo nos momentos mais complicados da minha vida, pela cumplicidade e por ser um homem de grandes qualidades. Amo-te muito!

Aos meus amigos Dr. Wanderley Granja Affonso e Elza Silva Affonso que me estimularam a entrar na vida de pesquisa acadêmica e que não me deixaram desistir pelas dificuldades que passei. Obrigada por serem meus Anjos de Luz e por serem os meus exemplos de vida, principalmente ao Dr. Wanderley excelente médico que exerce sua função com amor, humildade, simplicidade e fé. Obrigado por ser o meu exemplo!

À amiga e Dra. Basile, por me ajudar a tornar uma pessoa guerreira, e cultivar dentro de mim o amor à Ciência.

Às amigas: Priscila Oliveira de Carvalho, Graziela Macedo de Oliveira e Lívia Mallagoli pelo ombro amigo que foi durante este trajeto da minha vida.

Às amigas: Léia Cristina Rodrigues da Silva e Liã Bárbara Arruda pelo ombro amigo, por sempre estarem por perto com palavras de apoio nos meus momentos difíceis de aprendizado. Obrigada pelas orientações, 
alegrias e confiança. E por colaborarem na revisão da minha dissertação, e pela valiosa troca de conhecimentos.

À Tatiana Negri Santi, Soraya Ogusuku, Noemia Mie Orii, Rosangela Maria Araújo, Mariana de Lucena Palma pelas orientações, por toda a ajuda para que eu pudesse concluir este projeto.

A todos os integrantes e colegas do LIM-56 pela força e orientação que cada um passou para mim.

Ao grupo de Imunodeficiências Primárias, em especial a Alana dos Santos Dias, Thiago de Almeida Bezerra, Thiago Pires de Oliveira, a Laís Almeida Pinto e Bosco Christiano Maciel da Silva pela oportunidade de aprender profissionalmente e pessoalmente.

Ao Dr. Dewton de Moraes Vasconcelos por me orientar, confiar e esclarecer as minhas dúvidas durante a realização do projeto. Aprendi muito, obrigado por me ensinar a caminhar com minhas próprias pernas.

Ao Dr. Maurício Domingues Ferreira por confiar a mim o projeto, pelos esclarecimentos e pelas orientações.

À Dra. Maria Notomi Sato por me ajudar a encontrar o rumo da minha vida durante o mestrado. Obrigada.

Ao Prof. Dr. Alberto José da Silva Duarte por permitir que eu realizasse o meu projeto de Mestrado em seu laboratório, sem a sua permissão eu não poderia realizar este grande sonho em minha vida. 
Ao Laboratório de Micologia (LIM-53) do Instituto de Medicina Tropical da Faculdade de Medicina da Universidade de São Paulo, e a Roseli por todos os esclarecimentos de técnicas.

Aos pacientes que voluntariamente participaram deste estudo, sem os quais a realização do mesmo seria impossível.

À banca de qualificação, pelas críticas construtivas que fizeram para que eu terminasse com "chave de ouro" a dissertação.

A todos o meu muitíssimo obrigado, por fazer tornar realidade esse meu sonho.

Obrigada a Todos!!!! 
Esta dissertação ou tese está de acordo com as seguintes normas, em vigor no momento desta publicação: Referências: adaptado de International Committee of Medical Journals Editors (Vancouver).

Universidade de São Paulo. Faculdade de Medicina. Divisão de Biblioteca e Documentação. Guia de apresentação de dissertações, teses e monografias. Elaborado por Anneliese Carneiro da Cunha, Maria Julia de A. L. Freddi, Maria F. Crestana, Marinalva de Souza Aragão, Suely Campos Cardoso, Valéria Vilhena. 3a ed. São Paulo: Divisão de Biblioteca e Documentação; 2011.

Abreviaturas dos títulos dos periódicos de acordo com List of Journals Indexed in Index Medicus. 


\section{Sumário}

Lista de Abreviaturas

Lista de Símbolos

Lista de Figuras

Lista de Tabelas

Resumo

Summary

1. Introdução 01

$\begin{array}{ll}\text { 2. Justificativa } & 27\end{array}$

3. Objetivo 28

4. Casuística 29

5. Materiais e Métodos 33

6. Resultados 46

7. Discussão 62

8. Conclusões 67

$\begin{array}{ll}\text { 9. Anexos } & 69\end{array}$

10. Referências Bibliográficas 92

Apêndices 


\section{Lista de Abreviaturas}

Ac - Anticorpo

ADEE-3003 - Ambulatório das Manifestações Dermatológicas das Imunodeficiências Primárias - Serviço de Dermatologia - HCFMUSP

Ag - Antígeno

B - Células B

BCG - Mycobacterium bovis, bacilo de Calmette-Guérin

C - Carboxi-terminal

$\mathrm{Ca}^{+2}$ - Cálcio

CAPPesq - Comissão de Ética para Avaliação de Projetos de Pesquisa

CARD 9 - Domínio de recrutamento de ativação da Caspase 9

CD3 - Marcador de linfócito T totais

CD4 - Marcador de linfócito T auxiliador

CD8 - Marcador de linfócito T citotóxico

CD16 - Marcador de linfócitos natural killer e monócitos

CD19 - Marcador de linfócito B

CD20 - Marcador de linfócito B

CD56 - Marcador de linfócitos natural killer 
CD206 - Receptor de Manose de monócitos

CDR - Reconhecimento de Carboidrato

C/ EBP $\beta$ - Alvo transcripcional de NF-IL-6 (CCAAT/enhancer-binding protein beta)

CLEC4E - Proteína Transmembrânica tipo II de Mincle

CLECSF9 - Proteína Transmembrânica tipo II expressa em células mielóides

CLEC4A - Imunoreceptor de célula dendrítica

CLEC7A - Dectina - 1

CLRs - receptores de lectina do tipo C

CMA - Antígeno metabólico de Candida albicans

$\mathrm{CO}_{2}$ - Gás Carbônico

CXCL1 - Ligante 1 de quimiocina da família CXC

CXCL2 - Proteína Inflamatória de Macrófago 2 alfa

et al $-E$ outros

DD - Domínio de morte

DC - Célula Dendrítica

DCIR - Imunoreceptor de Células Dendríticas

DNA - Ácido Desoxirribonucléico 
DNAX - Proteína de ativação

DAP12 - Gene de peso molecular 12 Daltons

ELISA - Ensaio imunoenzimático

EPN - Seqüência de aminoácidos Glu-Pro-Asn

Fc - Fração Cristalizável da região constante das imunoglobulinas

$\mathrm{FeSO}_{4}-$ Sulfato Ferroso

FITC - Isotiocianato de fluoresceína

fMLP - formil-metionil-fenilalanina

FcRc - Receptor c da cadeia Fc

FcR $\gamma$ - Receptor Fc gamma (receptor para a fração cristalizável da lgG)

GM-CSF - Fator estimulador de colônias de granulócitos e monócitos

HCFMUSP - Hospital das Clínicas da Faculdade de Medicina da Universidade de São Paulo

$\mathrm{HCl}$ - Ácido Clorídrico

$\mathrm{H}_{2} \mathrm{O}_{2}$ - Peróxido de Hidrogênio

$\mathrm{H}_{2} \mathrm{SO}_{4}$ - Ácido Sulfúrico

IFN-y - Interferon - gama

$\lg \mathrm{A}$ - Imunoglobulina A 
$\lg \mathrm{E}$ - Imunoglobulina $\mathrm{E}$

IgG - Imunoglobulina G

IgM - Imunoglobulina M

IL-1 - Interleucina - 1

IL-1Rs - Receptores de interleucina -1

IL-2 - Interleucina - 2

IL-4 - Interleucina - 4

IL-5 - Interleucina - 5

IL-6 - Interleucina - 6

IL-10 - Interleucina - 10

IL-13 - Interleucina - 13

IL-12 - Interleucina - 12

IL-23 - Interleucina - 23

IRAK - Quinase associada ao Receptor da Interleucina 1

IRAK1 - Quinase 1 associada ao Receptor da Interleucina 1

IRAK2 - Quinase 2 associada ao Receptor da Interleucina 1

IRAK4 - Quinase 4 associada ao Receptor da Interleucina 1

IRAK-M - Quinase M associada ao Receptor da Interleucina 1 
ITAM - Motivo de Ativação de imunotirosina

KC - Quimiocina derivada de queratinócitos

$\mathrm{KCl}$ - Cloreto de Potássio

kDa - Quilodalton

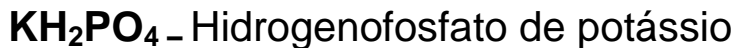

LPS - Lipopolissacarídeos

LRR - Região rica em leucinas

$\mathrm{MgSO}_{4}-$ Sulfato de Magnésio

MHC I - Complexo Principal de Histocompatibilidade de Classe I

MHC II - Complexo Principal de Histocompatibilidade de Classe II

Mincle - Lectina do tipo C induzida por macrófagos

Mincle-Fc - Proteína de fusão recombinante de Mincle com a região Fc da imunoglobulina $G$

MIP-2 - Proteína Inflamatória de Macrófago 2

MR - Receptor de Manose

MyD88 - Gene de resposta primária de diferenciação Mielóide

$\mathbf{N}$ - Região amino terminal

$\mathrm{NaCl}$ - Cloreto de Sódio 
$\mathrm{NaHCO}_{3}-$ Bicarbonato de Sódio

$\mathrm{NaNO}_{3}-$ Nitrato de Sódio

NF-кB - fator nuclear-карpa B

NF-IL6 - Fator nuclear de Interleucina - 6

NK - Célula Natural Killer

NLR - Receptor similar a NOD

NOD - Domínio de oligomerização ligado a nucleotídeo

OKT3 - Anticorpo monoclonal anti-CD3

PAMPs - Padrões Moleculares Associados aos Patógenos

PBMC - Células mononucleares do sangue periférico

PBS - Salina tamponada com fosfato

PHA - Fitohemaglutinina

PE - Ficoeritrina

PE-Cy5 - Ficoeritrina-Cianina 5

PRRs - Receptores de reconhecimento de padrões

PPM - Padrão de Peso Molecular

PWM - Mitógeno de Pokeweed (Phytolacca americana)

RIG-I - Gene I induzido por ácido retinóico 
RPMI-1640 - Meio suplementado para cultura de leucócitos (de Roswell Park Memorial Institute)

SDS - PAGE - Gel de Poliacrilamida contendo Dodecil sulfato de sódio

Src - Família das tirosinas quinases Src

Syk - Tirosina quinase esplênica

TDB - trehalose-6, 6-dibehenato

TDM - trehalose-6,6'- dimicolato

TEMED - Tetrametiletilenodiamina

$\mathbf{T}_{\mathrm{h}} \mathbf{1}$ - Célula T helper (auxiliar) 1

$T_{h} 2$ - Célula T helper (auxiliar) 2

Th17 - Célula T helper (auxiliar) 17

TIR - Domínio de Toll-like e receptor de interleucina - 1

TMB - Tetrametil Benzidina

TNF - Fator de necrose tumoral

TNF- $\alpha$ - Fator de necrose tumoral - alfa

TNF- $\beta$ - Fator de necrose tumoral - beta

Tris/HCl - Tris tamponado com ácido clorídrico

TLR - Receptores similares a Toll 
TLR - 1 - Toll Like Receptor - 1

TLR-2 - Toll Like Receptor - 2

TLR - 3 - Toll Like Receptor - 3

TLR - 4 - Toll Like Receptor - 4

TLR - 7 - Toll Like Receptor - 7

TLR - 9 - Toll Like Receptor - 9 


\section{Lista de Símbolos}

$\alpha-$ Alfa

$\boldsymbol{\beta}$ - Beta

@C - Graus Celsius

E - Extrato antigênico obtido a partir do cultivo do Trichophyton rubrum

G - Medida equivalente a força gravitacional na superfície terrestre, ao nível do mar.

g - Grama

Glu-Pro-Asn - Sequência de aminoácidos ácido glutâmico-prolinaasparagina

IE - Índice de Estimulação

$\kappa$ - Kappa

M - Molar

mA - Mili ampère

mBq - Mega Becquerel

mL - Mililitro

nm - Nanômetro

$\%$ - Porcentagem 


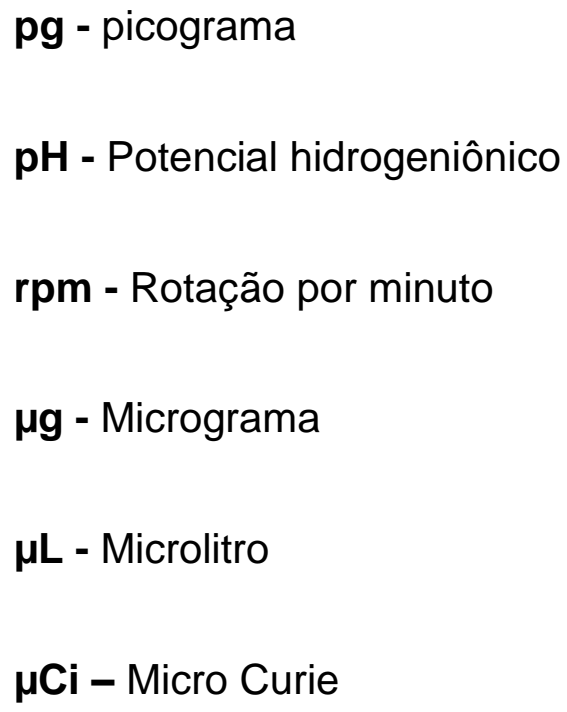

${ }^{3} \mathbf{H}-\mathbf{T d R}$ - Timidina Tritiada

V - Volts

W - Watts

YIIDTGIDID - Peptídeo sintético Tri r2 do Trichophyton rubrum (Tirosina isoleucina - isoleucina - ácido aspártico - treonina - glicina - isoleucina ácido aspártico - isoleucina - ácido aspártico)

Y - gamma 


\section{Lista de Figuras}

Figura 1 Estrutura linear do polissacarídeo (manana) presente na parede celular do fungo $T$. rubrum.

Figura 2 Esquema genérico de um citômetro de fluxo, mostrando

a fonte de luz (laser), a câmara de fluxo, os fotomultiplicadores (sensores) e os espelhos passabanda dicróicos.

Figura 3 Quantificação de linfócitos T, B e NK de controles e 39 pacientes por citometria de fluxo com os anticorpos monoclonais anti-CD3, anti-CD4, anti-CD8, anti-CD19 e anti-CD16/CD56.

Figura 4 Esquema explicativo da técnica de separação de células por gradiente de densidade de Ficoll-Hypaque e cultura linfoproliferativa de células mononucleares de sangue periférico com estímulos inespecíficos (mitógenos) e específicos (antígenos). A avaliação da resposta proliferativa celular é obtida por meio da incorporação de timidina triciada ao DNA das células em divisão celular.

Figura 5 Esquema explicativo da técnica de ELISA (Enzyme 44 Linked Immunosorbent Assay) para citocinas IL-4, IL-10, 
IL-12 e IFN-y.

Figura 6 Coloração por TMB na dosagem de citocinas pela técnica de ELISA.

Figura 7 Dosagem de citocinas; a reação é interrompida por Ácido Sulfúrico.

Figura 8 Resposta linfoproliferativa ao extrato do Trichophyton 48

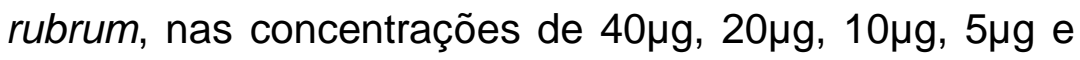
2,5 $\mu \mathrm{g}$, conforme quantificação de proteínas realizada pelas técnicas de Bradford e Lowry.

Figura 9 Gel de poliacrilamida (SDS-PAGE) mostrando a presença 49 das proteínas do fungo Trichophyton rubrum, apresentando os dados de peso molecular em $\mathrm{kDa}$ (quilodaltons). Observam-se proteínas com pesos moleculares de aproximadamente $60 \mathrm{kDa}, 50 \mathrm{kDa}$ e 35 $\mathrm{kDa}$ em concentrações diferentes.

Figura 10 Quantificação do número de células imunocompetentes dos indivíduos do grupo controle. Os dados relativos a linfócitos $T, B$ e células NK em número absoluto (eixo Y1, à esquerda) e da expressão percentual de CD206, o receptor de manose de monócitos (eixo Y2, à direita).

Figura 11 Quantificação do número de células imunocompetentes dos indivíduos do grupo controle. Os dados relativos a 
linfócitos T, B e células NK em número absoluto (eixo Y1, à esquerda) e da expressão percentual de CD206, o receptor de manose de monócitos (eixo Y2, à direita).

Figura 12 Comparação entre o grupo de controles e de pacientes sob estímulo inespecífico pelo PWM e por antígeno não relacionado (CMA). Resultados apresentados em índice de estimulação (eixo Y). Considera-se uma resposta normal um Índice de Estimulação $\geq 3$ para CMA, e $\geq 10$ para PWM.

Figura 13 Resposta linfoproliferativa dos indivíduos do grupo controle a diferentes concentrações do extrato antigênico derivado do fungo Trichophyton rubrum. Resultados apresentados em índice de estimulação (eixo Y). Resposta positiva $>3$.

Figura 14 Resposta linfoproliferativa dos indivíduos do grupo paciente a diferentes concentrações do extrato antigênico derivado do fungo Trichophyton rubrum. Resultados apresentados em índice de estimulação (eixo Y). Resposta positiva $>3$.

Figura 15 Resposta linfoproliferativa dos indivíduos do grupo 56 controle a diferentes concentrações do peptídeo antigênico imunodominante (YIIDTGIDID) derivado do 
fungo Trichophyton rubrum. Resultados apresentados em índice de estimulação (eixo Y). Resposta positiva > 2.

Figura 16 Resposta linfoproliferativa dos indivíduos do grupo paciente a diferentes concentrações do peptídeo antigênico imunodominante (YIIDTGIDID) derivado do fungo Trichophyton rubrum. Resultados apresentados em índice de estimulação (eixo Y). Resposta positiva > 2.

Figura 17 Comparação da resposta linfoproliferativa (I.E.) dos 58 indivíduos do grupo controle e dos pacientes a diferentes concentrações do extrato antigênico derivado do fungo Trichophyton rubrum. Resultados apresentados em índice de estimulação (eixo Y). Resposta positiva $>3$.

Figura 18 Comparação da resposta linfoproliferativa dos indivíduos 59 do grupo controle e dos pacientes a diferentes concentrações do peptídeo antigênico imunodominante (YIIDTGIDID) derivado do fungo Trichophyton rubrum. Resultados apresentados em índice de estimulação (eixo Y). Resposta positiva $>2$.

Figura 19 Comparação da secreção de IL-4 por células 60 mononucleares estimuladas por mitógeno (PHA) durante 24 horas, e por antígenos: CMA e o peptídeo YIIDTGIDID na diluição de $1 / 25$ durante 72 horas, dos indivíduos do 
grupo controle e dos pacientes. Resultados apresentados em $\mathrm{pg} / \mathrm{mL}$ de IL-4 (eixo Y).

Figura 20 Comparação da secreção de IL-10 por células mononucleares estimuladas por mitógeno (PHA) durante 24 horas, e por antígenos: CMA e o peptídeo YIIDTGIDID na diluição de 1/25 durante 72 horas, dos indivíduos do grupo controle e dos pacientes. Resultados apresentados em pg/mL de IL-10 (eixo Y)

Figura 21 Comparação da secreção de IL-12 por células 62 mononucleares estimuladas por mitógeno (PHA) durante 24 horas, e por antígenos: CMA e o peptídeo YIIDTGIDID na diluição de 1/25 durante 72 horas, dos indivíduos do grupo controle e dos pacientes. Resultados apresentados em pg/mL de IL-12 (eixo Y).

Figura 22 Comparação da secreção de IFN-gama por células mononucleares estimuladas por mitógeno (PHA) durante 24 horas, e por antígenos: CMA e o peptídeo YIIDTGIDID na diluição de 1/25 durante 72 horas, dos indivíduos do grupo controle e dos pacientes. Resultados apresentados em $\mathrm{pg} / \mathrm{mL}$ de IFN-gama (eixo Y). 


\section{Lista de Tabelas}

Tabela 1 Relação de controles positivos que em algum momento da vida apresentaram micose.

Tabela 2 Relação de pacientes com dermatofitose causada por Trichophyton rubrum.

Tabela 3 Índices de Estimulação das Culturas de Linfócitos de 52 seis dias, para o grupo Controle. Considera-se Índice de Estimulação positivo $\geq 3$ para antígenos, $\geq 2$ para peptídeos, e $\geq 10$ para o mitógeno do PWM.

Tabela 4 Índices de Estimulação, das Culturas de Linfócitos de 53 seis dias, para o grupo de Pacientes com Dermatofitose Extensa. Considera-se Índice de Estimulação positivo $\geq$ 3 para antígenos, $\geq 2$ para peptídeos, e $\geq 10$ para 0 mitógeno do PWM.

Tabela 5 Análise dos Índices de Estimulação das Culturas de 78 Linfócitos de seis dias, para o grupo Controle

Tabela 6 Dados individuais da cultura de Linfoproliferação de 79 células do sangue periférico do grupo Controle

Tabela 7 Índices de Estimulação das Culturas de Linfócitos de 80 seis dias, para o grupo de Pacientes com Dermatofitose Extensa

Tabela 8 Dados individuais, da cultura de Linfoproliferação de 6 81 dias, para o grupo de Pacientes com Dermatofitose 
Extensa

Tabela 9 Fenotipagem celular para o grupo Controle 82

Tabela 10 Fenotipagem celular para o grupo Pacientes com 83 Dermatofitose Extensa

Tabela 11 Dados individuais de quantificação de citocina IL-4 do grupo Controle

Tabela 12 Dados individuais de quantificação de citocina IL-4 para o grupo de Pacientes com Dermatofitose Extensa

Tabela 13 Dados individuais de quantificação de citocina IL-10 do grupo Controle

Tabela14 Dados individuais de quantificação de citocina IL-10 para 85 o grupo de Pacientes com Dermatofitose Extensa

Tabela 15 Dados individuais de quantificação de citocina IL-12 do 86 grupo Controle

Tabela 16 Dados individuais de quantificação de citocina IL-12 para 86 o grupo de Pacientes com Dermatofitose Extensa

Tabela 17 Dados individuais de quantificação de citocina IFN-gama do grupo Controle

Tabela 18 Dados individuais de quantificação de citocina IFN-gama para o grupo de Pacientes com Dermatofitose Extensa 


\section{Resumo}

Bressani VO. Caracterização da Resposta Imunológica Celular em Pacientes Portadores de Dermatofitoses Extensas Causada por Trichophyton rubrum [Dissertação]. São Paulo: Faculdade de Medicina, Universidade de São Paulo; 2011.

Os dermatófitos são fungos que apresentam a capacidade de invadir o estrato córneo da pele e de outros tecidos queratinizados como os cabelos e as unhas. Esses fungos podem provocar infecções em qualquer local da pele, no entanto os pés, região inguinal, axilas, couro cabeludo e unhas são mais freqüentemente afetados.

O Trichophyton rubrum é um fungo antropofílico responsável por aproximadamente $80 \%$ das micoses superficiais em humanos. Indivíduos saudáveis podem apresentar dermatofitoses, embora nesses indivíduos a doença ocorra de forma localizada. Por outro lado, indivíduos que apresentam comprometimento da imunidade celular tendem a apresentar formas mais disseminadas.

Tendo o objetivo de avaliar a resposta imunológica celular de pacientes portadores de dermatofitoses extensas causadas pelo Trichophyton rubrum, utilizamos um método bastante sensível de avaliação da imunidade celular que mede a resposta linfoproliferativa a mitógenos como: a fitohemaglutinina (PHA); o anti-CD3 (OKT3); e o Pokeweed (PWM). Foram avaliadas também as respostas linfoproliferativas para antígenos como: o antígeno metabólico 
de Candida sp (CMA); o extrato antigênico do Trichophyton rubrum, e o peptídeo sintético (YIIDTGIDID) que corresponde ao principal epítopo do fungo. Avaliamos também a dosagem das citocinas IL-4, IL-10, IL-12 e IFN-Y sob estímulo inespecífico pela PHA e CMA, e sob estímulo específico pelo peptídeo imunodominante do fungo.

Os resultados da imunofenotipagem celular para CD3, CD4, CD8, CD19, CD56 e CD206 nos mostraram que não houve diferença entre os grupos de controles e pacientes. Os resultados dos ensaios de linfoproliferação demonstraram diferenças significativas entre os grupos controles e pacientes sob o estímulo inespecífico do PWM e ao antígeno não relacionado CMA. Houve semelhança dos resultados para os grupos controles e pacientes frente ao estímulo pelo extrato antigênico, e diferenças significativas entre os grupos controles e pacientes frente ao peptídeo imunodominante, onde o índice de estimulação foi nitidamente superior para o grupo controle. A quantificação de citocinas demonstrou diferença significativa apenas para IFN-y entre os grupos de controles e pacientes sob os estímulos de PHA e do peptídeo sintético.

Podemos concluir que o extrato fúngico obtido é antigênico e induz linfoproliferação. No entanto, a resposta ao peptídeo YIIDTGIDID (Tri r2) foi mais específica.

Nosso trabalho demonstrou que nem todos os pacientes com Dermatofitoses extensas apresentam uma resposta celular deficiente, pois esses pacientes 
demonstram respostas tanto para o extrato quanto para o peptídeo antigênico de Trichophyton rubrum.

Descritores: Dermatomicoses; Trichophyton rubrum; Citocinas; Linfócitos; Imunidade. 


\section{Summary}

Bressani VO. Characterization of the Cellular Immunity in Patients Presenting Extensive Dermatophytoses due to Trichophyton rubrum [Dissertation]. São Paulo: Faculdade de Medicina, Universidade de São Paulo; 2011.

Dermatophytes are fungi that have the ability to invade the stratum corneum of the skin and other keratinized tissues such as hair and nails. These fungi can cause infections anywhere on the skin, however the feet, inguinal region, axillae, scalp and nails are most often affected.

Trichophyton rubrum is an anthropophilic fungus responsible for approximately $80 \%$ of superficial mycoses in humans. Healthy individuals can present dermatophytoses, although in these individuals the involvement occurs on localized areas. On the other hand, individuals with impaired cellular immunity tend to have disseminated forms.

With the aim of evaluating the cellular immune response of patients with extensive dermatophytosis caused by Trichophyton rubrum, we used a very sensitive method for assessing cellular immunity, measuring the lymphoproliferative response to mitogens such as: phytohemagglutinin (PHA); anti-CD3 (OKT3); and pokeweed (PWM). We also evaluated the lymphoproliferative response to antigens as: the metabolic antigen of Candida sp (CMA), the antigenic extract of Trichophyton rubrum; and the synthetic peptide (YIIDTGIDID) that corresponds to the main fungal epitope . 
We also evaluated the levels of IL-4, IL-10, IL-12 and IFN-y after stimulation by PHA, CMA, and the immunodominant peptide of the fungus.

The immunophenotyping results showed no differences between the groups of patients and controls. The lymphoproliferation test results showed significant differences between the groups of patients and controls under the PWM and CMA stimuli. There were similar results for the groups of controls and patients after the antigenic stimulation by the extract, and significant differences between the groups of controls and patients against the immunodominant peptide, being the stimulation index significantly higher for the control group. The cytokines quantification showed a significant difference between the groups of controls and patients only for IFN-y under PHA and the synthetic peptide stimulation. We can conclude that the obtained fungal extract is antigenic and can stimulate lymphoproliferation. However the response to the peptide YIIDTGIDID (Tri r2) was more specific.

We showed that not all patients with extensive dermatophytosis have an impaired cellular response, demonstrating responses to both the extract and the antigenic peptide of $T$. rubrum.

Keywords: Dermatomycosis; Trichophyton rubrum; Cytokines; Lymphocytes, Immunity. 


\section{INTRODUÇÃO}

\subsection{Infecções fúngicas}

As infecções fúngicas atualmente vêm rivalizando com as bacterianas como um problema significativo em inúmeros ambientes, sendo as micoses superficiais (Dermatofitoses) extremamente comuns em países tropicais como o Brasil. Os dermatófitos são fungos que apresentam a capacidade de invadir o estrato córneo da pele e de outros tecidos queratinizados como os cabelos e as unhas. Esses fungos podem provocar infecções em qualquer local da pele, no entanto os pés, região inguinal, axilas, couro cabeludo e unhas são mais frequentemente acometidos. Existem três gêneros de fungos dermatófitos patogênicos - Trichophyton, Microsporum e Epidermophyton. Esses organismos queratinofílicos provavelmente desenvolveram-se a partir de fungos saprofíticos do solo. Embora alguns dermatófitos não sejam capazes de provocar doenças, a maioria desses organismos apresenta comportamento de parasitas, adaptando-se a um ou alguns hospedeiros. Os dermatófitos: $T$. rubrum, seguido pelo $T$. mentagrophytes, são os agentes etiológicos mais importantes das dermatofitoses em humanos, representando cerca de $80 \%$ dos casos isolados no Brasil; dentre estes, 80 a 93\% representam casos recorrentes de dermatofitoses por T. rubrum (Esquenazi et al., 2004).

A taxonomia desses fungos é complicada pelo fato de que a maioria dos isolados clínicos compreende fungos que não produzem estruturas sexuais em cultura. Entretanto, formas sexuadas de muitas dessas espécies 
são conhecidas, pertencendo a um de dois gêneros, Arthroderma e Nannizzia, que correspondem aos gêneros Trichophyton e Microsporum, respectivamente. As relações entre as diferentes espécies, assim como de cepas de uma mesma espécie são importantes no entendimento da disseminação das infecções, porém, a classificação desses fungos é ainda matéria de debate (De Vroey, 1985). Existem tentativas de classificação por homologia do DNA (Davison \& Mackenzie, 1984), composição protéica (Jeffries et al, 1984) produção de antibióticos ou enzimas, fatores que têm importância na patogênese desses fungos (MacGregor et al, 1992).

Os fatores epidemiológicos que afetam a distribuição e transmissão das dermatofitoses são amplamente dependentes da fonte da infecção (Rippon, 1985), ou seja, solo (dermatófitos geofílicos), animais (dermatófitos zoofílicos) ou humanos (dermatófitos antropofílicos). No entanto, os dermatófitos antropofílicos são os mais freqüentes causadores de dermatofitoses. O mais comum desses organismos é o Trichophytum rubrum, que causa desde a tinea pedis ou tinea cruris em locais de clima temperado até a tinea corporis, particularmente nos trópicos. A capacidade desse fungo em provocar infecções crônicas não inflamatórias da pele, facilmente transmitidas, é provavelmente um fator primordial na sua disseminação nos últimos anos (Rippon, 1985). A infecção é usualmente transmitida por meio do contato com escamas de pele descamadas. $\mathrm{Na}$ maioria dos casos a infecção é pelo Trichophyton rubrum, embora o Trichophyton interdigitale (mentagrophytes) também possa ser encontrado (Gentles \& Evans, 1973). O Epidermophyton floccosum também pode ser 
responsável por causar tinea pedis, embora seja mais frequentemente associado à tinea cruris. A tinea corporis (imbricata) é causada pelo Trichophyton concentricum, sendo encontrada em regiões tropicais remotas como a bacia do Rio Amazonas (Hay, 1987). A distribuição de alguns dos fungos antropofílicos causadores da tinea corporis ou de onicomicoses, assim como da tinea capitis em crianças costuma ser restrita. Segundo Chinelli e colaboradores (2003), na última década (1992-2002), seis espécies de dermatófitos foram detectadas como agentes de dermatofitoses na cidade de São Paulo: T. rubrum, T. mentagrophytes, M. canis, E. floccosum, T. tonsurans e M. gypseum. O predomínio de T. rubrum (48,7\%) representa uma tendência mundial e os dados atuais são consistentes com os relatados em estudos realizados no Sul, Sudeste, Centro-Oeste e Nordeste do Brasil.

A dermatite causada pela infecção pelo Trichophyton schoenleinii, denominada favo, apresenta achados clínicos característicos, como o desenvolvimento de crostas no couro cabeludo. Os cabelos são invadidos, porém sua clivagem é retardada devido ao fato de não estarem estruturalmente danificados até tardiamente na infecção. Embora a tinea capitis seja usualmente uma doença de crianças, mulheres adultas com favo são ocasionalmente observadas. Dermatófitos causadores de infecção do couro cabeludo podem ser encontrados na superfície cutânea, porém sem invadir a pele ou os cabelos. Uma pequena proporção de portadores desenvolve a infecção dentro de um período de seis meses, enquanto outros 
se livram do fungo, permanecendo os restantes portadores, sendo que 0 mesmo pode ser observado nas infecções dos pés (Ive, 1966).

A transferência de organismos infectantes do solo, outros animais ou de humanos é mediada pelos artrósporos, que são células vegetativas com paredes espessas formadas pelas hifas de dermatófitos, in vivo e in vitro. É provável que essas estruturas sejam espalhadas pelo hospedeiro primário através de escamas de pele ou pêlos. Sabe-se que os artrósporos podem sobreviver longe dos hospedeiros por períodos consideráveis, de até quinze meses ou mais. Para o desenvolvimento da dermatofitose é necessário o contato direto entre um indivíduo infectado e outro não. O processo de transferência é pouco conhecido, mas sabe-se que a invasão da pele se segue à aderência das células do fungo aos queratinócitos, e a germinação subsequente leva à invasão (Zurita \& Hay, 1987).

A suscetibilidade à infecção não é universal. Estudos em camundongos experimentalmente infectados com Trichophyton quinckeanum evidenciaram que existe considerável variação entre as linhagens na suscetibilidade às dermatofitoses (Calderon, 1989). Em humanos tem sido sugerido que a suscetibilidade à tinea imbricata é mediada por um gene autossômico recessivo, de acordo com estudos conduzidos em populações de Papua, Nova Guiné (Sergeantson \& Lawrence, 1977). Os fatores que determinam a suscetibilidade individual às dermatofitoses não são conhecidos, porém variações na composição de ácidos graxos inibitórios no sebo oferecem uma explicação. Outros fatores da superfície da pele importantes na evolução da infecção incluem a 
presença local de dióxido de carbono e a presença de umidade na superfície. O suor e o soro também contêm substâncias inibitórias, como a transferrina que, em seu estado não saturado, é inibitória para o crescimento de dermatófitos (King et al., 1975).

Em camundongos e cobaias experimentalmente infectados, a resposta inflamatória à dermatofitose é máxima após $9-16$ dias, sendo que após esse período há resolução da infecção, conquanto o principal mecanismo da resistência imunológica é dependente dos linfócitos $\mathrm{T}$. Na infecção murina por Trichophyton quinckeanum observou-se que a resistência é passivamente transmitida por linfócitos T CD4+, não sofrendo influência pela administração de anticorpos específicos (Calderon, 1989). A atividade de linfócitos $T$ supressores pode ser observada em células dos linfonodos de drenagem no pico da infecção. A despeito da dificuldade em extrapolar esses dados para a infecção em humanos, existem evidências de que a cinética da resposta imune em humanos seja similar. Por exemplo, em crianças portadoras de tinea capitis secundária ao Trichophyton tonsurans, o desenvolvimento de resposta de hipersensibilidade de tipo tardio correlaciona-se com a cura. Humanos infectados experimentalmente desenvolvem tanto a reação cutânea de hipersensibilidade tardia à tricofitina (proteína/toxina excretada pelo Trichophyton), quanto à resposta blastogênica de linfócitos T com evolução para cura (Jones et al.,1974, Blake et al., 1991).

Infecções crônicas por dermatófitos, em contraste com a infecção cutânea aguda, são caracterizadas por lesões menos inflamatórias, sendo 
que a maioria dos indivíduos infectados exibe uma reação negativa de hipersensibilidade tardia a tricofitina. Isso ocorre porque 0 T. rubrum deve suprimir a inflamação e a imunidade celular, a qual tem capacidade de induzir respostas à infecção (Blake et al., 1991). Pacientes com infecções crônicas pelo Trichophyton rubrum ou pelo Trichophyton concentricum parecem apresentar respostas imunes celulares defeituosas (Hay et al., 1983). Essas observações sugerem que a ativação de linfócitos T é crítica para a recuperação nas dermatofitoses. O braço aferente da resposta imune é decorrente das células de Langerhans, que funcionam como células apresentadoras de antígenos em culturas mistas com linfócitos humanos. Os mecanismos pelos quais os linfócitos afetam a recuperação são pouco conhecidos. Fagócitos mononucleares e principalmente neutrófilos (polimorfonucleares) podem lisar dermatófitos tanto intra como extracelularmente, principalmente através da via oxidativa (Calderon, 1989). Antígenos de dermatófitos são quimiotáticos para leucócitos humanos e ativam a via alternativa do complemento. No entanto, com exceção da tinea inflamatória, raramente se encontram neutrófilos como parte do infiltrado inflamatório, de modo que outros mecanismos de clearance (clareamento) de fungos devem estar envolvidos. Observa-se um turnover (viragem) epitelial elevado durante a infecção, que atinge seu pico concomitantemente ao máximo da resposta imunológica. É possível que a eliminação dos dermatófitos se acompanhe de descamação do estrato córneo e que o sistema imune amplifique uma resposta endógena da epiderme à infecção (Calderon, 1989). 
A parede celular do $T$. rubrum é composta por dois tipos de polissacarídeos, as mananas e as galactomananas (Figura 1). Em ensaios de linfoproliferação, Blake et al (1991) demonstraram que estas mananas suprimiam a resposta celular a uma variedade de antígenos e mitógenos in vitro (Ning et al, 2002).

Figura 1 - Manana, polissacarídeo presente na parede celular do Trichophyton rubrum.

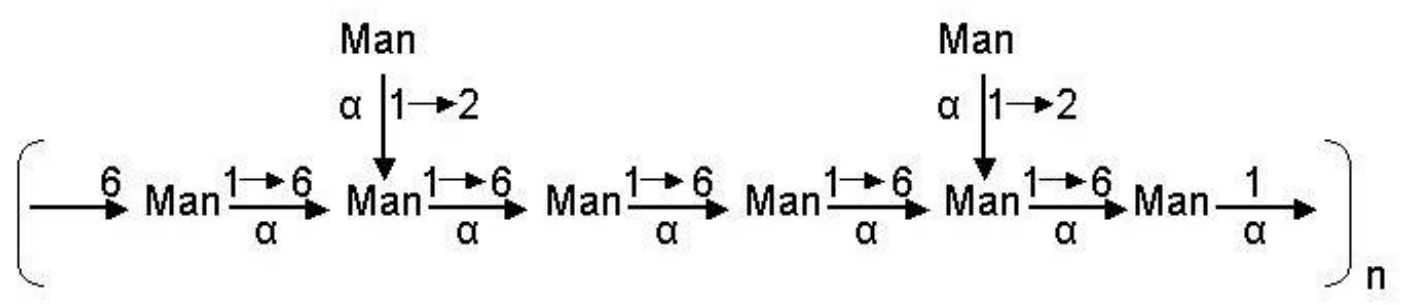

A manana tem estrutura linear constituída de unidades de manoses $\alpha-(1 \rightarrow 6)$ ligadas entre si, e unidades de manoses $\alpha-(1 \rightarrow 2)$ ligadas à cadeia lateralmente. Fonte: NING et al, 2002.

Diferentes espécies de dermatófitos variam em sua capacidade de elicitar uma resposta imune, com alguns organismos como o Trichophyton rubrum causando infecções crônicas ou recidivantes e outros, como o Trichophytum verrucosum, induzindo resistência prolongada a reinfecção. Alguns dermatófitos produzem glicopeptídeos que são capazes de inibir reversivelmente a blastogênese de linfócitos $T$ in vitro podendo, dessa forma, modular a imunidade (Macgregor et al., 1992)

É importante ressaltar que os dermatófitos causam infecção independente do estado imunológico do paciente, mas, em comum com outras infecções, o aspecto clínico se altera em indivíduos imunodeficientes. 
As lesões por dermatófitos são usualmente menos inflamadas em pacientes com comprometimento da função de linfócitos $T$, mas de modo paradoxal, em alguns pacientes as lesões são pustulosas e extensas e é freqüente um comprometimento folicular nesses pacientes. (Hay, 1995).

No tocante às manifestações clínicas disseminadas, a tinea corporis é uma das mais comuns manifestações cutâneas erroneamente diagnosticadas. Os locais freqüentemente afetados são o tronco e os membros. O prurido é variável, e as lesões podem ser únicas ou múltiplas (Wilson \& Plunkett, 1954).

Geralmente as infecções por fungos antropofílicos como o Trichophytum rubrum são menos inflamatórias e menos claramente demarcadas, sendo que em alguns pacientes é necessário examinar cuidadosamente para delimitar a lesão. As lesões são usualmente hiperpigmentadas em indivíduos de pele mais escura. Em pacientes com distúrbios da função dos linfócitos T a descamação é usualmente mínima, constituindo-se a lesão de pápulas ou pústulas agrupadas sem eritema significativo (Wilson \& Plunkett, 1954).

Em raras ocasiões pacientes sabidamente imunocomprometidos ou aparentemente normais desenvolvem infecções por dermatófitos que invadem os tecidos subcutâneos através dos vasos linfáticos, usualmente causando agrupamentos de granulomas, linfoedema e seios de drenagem (Allen et al., 1977). Ocasionalmente agregados de hifas de fungos lembrando as encontradas nos eumicetomas são encontrados em cortes histológicos. Esses "micetomas" de dermatófitos podem ser circundados por 
abscessos de neutrófilos, porém, freqüentemente as hifas são engolfadas por células gigantes nas seções de tecido. As infecções profundas por dermatófitos podem estender-se envolvendo os linfonodos de drenagem ou outros sítios como o fígado e o cérebro, podendo ser fatal (Allen et al., 1977).

A primeira barreira à infecção nos seres humanos é a pele ou as mucosas intactas. Qualquer processo que cause maceração da pele deixa a área envolvida suscetível à invasão pelos fungos, mesmo em indivíduos saudáveis. Além disso, a flora bacteriana da pele e do trato gastrintestinal também serve como proteção, através da competição com o fungo pelos nutrientes, o que resulta na inibição de seu crescimento (Durandeau et al., 1986).

A adesão do fungo à célula hospedeira pode ocorrer através dos carboidratos protéicos e lectinas encontrados na superfície do $T$. rubrum que interagem com os açúcares (manose, galactose, n-acetilglicosamina) na superfície das células hospedeiras, facilitando ou dificultando a sua endocitose, sugerindo que o T. rubrum possua a habilidade de, após invadir células hospedeiras, tornar-se capaz de expressar adesinas carboidratoespecíficas na superfície de sua microconídia que, por sua vez, reconhece manose e galactose. Essas adesinas podem desenvolver um importante papel na adesão e invasão dos fungos durante os processos de dermatofitoses. (Esquenazi et al., 2004).

A reação inflamatória aguda é também um importante mecanismo de defesa contra as infecções fúngicas, induzindo a migração dos fagócitos 
para o sítio da infecção fúngica (quimiotaxia), possibilitando a fagocitose, morte e digestão pelos fagócitos, tanto polimorfonucleares, neutrófilos, como também células mononucleares (Djawari et al., 1978).

Nos vertebrados, a imunidade inata é dependente de células fagocíticas mielóides que fagocitam e destroem os patógenos. Em grande parte, estas células têm capacidades autônomas: os neutrófilos são capazes de eliminar de forma eficiente bactérias não capsuladas, mas eles evoluíram para funcionar melhor em conjunto com as células e proteínas do sistema imune adaptativo. Por exemplo, os anticorpos produzidos por linfócitos B opsonizam as bactérias capsuladas, facilitando a destruição pelas células mielóides, que incluem os fagócitos mononucleares e polimorfonucleares. Os fagócitos mononucleares são derivados de monócitos do sangue, como os diversos tipos de macrófagos e as células dendríticas. Os fagócitos mononucleares são menos eficientes na destruição de agentes patogênicos, contudo são altamente eficientes na apresentação de antígenos às células T do sistema imune adaptativo. Os macrófagos são distribuídos por todo o corpo do hospedeiro, de modo que, caso um inóculo infeccioso se apresente por qualquer via, haverá um macrófago próximo do organismo invasor. Os macrófagos não são uma população uniforme de células, eles são morfologicamente diferentes, abrangendo, por exemplo, os histiócitos, as células de Kupffer presentes nos sinusóides hepáticos, e a microglia do sistema nervoso central. Os osteoclastos também são uma forma de macrófagos. As células dendríticas também assumem uma variedade de formas (por exemplo, as células de Langerhans da pele, as células 
dendríticas plasmacitóides do baço etc.). Elas existem como uma minoria entre os fagócitos mononucleares (Beutler, 2004).

Os macrófagos são capazes de engolfar e matar micróbios, mas talvez as suas funções mais importantes sejam de fiscalização. Através da elaboração de citocinas quimiotáticas, recrutam outras células mielóides e em particular, fagócitos polimorfonucleares, para o local da infecção. Os macrófagos e, mais ainda, as células dendríticas, também iniciam a resposta imune adaptativa para a maioria dos patógenos através da apresentação de antígenos para células $\mathrm{T} \mathrm{CD}^{+}$no contexto de antígenos do complexo principal de histocompatibilidade (MHC, do inglês Major Histocompatibility Complex) de classe II (Beutler, 2004).

Os fagócitos polimorfonucleares (que incluem os neutrófilos, basófilos e eosinófilos) são de importância fundamental na contenção da infecção. Os neutrófilos, em particular, são matadores especializados, dotados de uma vasta gama de armas para destruir sua presa microbiana. Os eosinófilos e basófilos estão mais relacionados com a produção de mediadores que dão forma ao ambiente inflamatório, e respondendo às citocinas elaboradas pelo sistema imune adaptativo. Essas células são normalmente muito mais raras do que os neutrófilos, mas particularmente os eosinófilos podem ser produzidos em grande número no curso das infecções parasitárias, ou como resultado de reações alérgicas respostas imunes adaptativas (Beutler, 2004).

O sistema imune inato evoluiu muito antes do sistema imune adaptativo, e em muitos aspectos, o mais antigo sistema suporta a função da 
mais recente. Assim, as células do sistema imune adaptativo são dependentes desses elementos mielóides. A eliminação de apenas um subconjunto de células efetoras imunes inatas (por exemplo, os neutrófilos) pode ser suficiente para provocar um estado de imunodeficiência profunda, mais grave do que a observada como resultado de Aplasia linfóide. Sem a fundamental ajuda das células apresentadoras de antígenos, uma função de células do sistema imune inato, e sem a produção de citocinas de origem na imunidade inata (incluindo $\mathrm{IL}-12$, IL-1, interferons do tipo I e TNF), as respostas imunes adaptativas são ineficazes. (Beutler, 2004).

Doenças fúngicas em indivíduos imunocompetentes são principalmente restritas a infecções superficiais e não-fatais na pele e mucosas. No entanto, em pacientes nos quais as atividades de sentinela do sistema imune são comprometidos, os fungos podem causar doença sistêmica com mortalidade o que corresponde ou excede as desafiadoras septicemias bacterianas (Mora-Montes et al., 2011).

O reconhecimento dos patógenos fúngicos pelas células da imunidade inata é um evento essencial para estabelecer os mecanismos de defesa do hospedeiro e, portanto a proteção a micoses. A identificação de moléculas microbianas denominadas padrões moleculares associadas aos patógenos (PAMPs) é realizado por receptores de reconhecimento de padrões, que em sua maioria estão localizados na superfície das células da imunidade inata do hospedeiro (Mora-Montes et al., 2011).

Os receptores similares a Toll (TLR, do inglês Toll-like receptors) atuam como sensores das moléculas microbianas (PAMPs) e permitem a 
caracterização imediata entre o próprio e o não-próprio, uma necessidade do sistema imune. Mas não podemos esquecer que o sistema imune inato tem outras ferramentas para melhor reconhecer os patógenos microbianos, tais como o sistema complemento, os receptores especializados das células natural killer, e alguns sensores intracelulares. Todas essas moléculas que compõem esse sistema para a percepção microbiana são complementares e estão envolvidos no desenvolvimento da consequente resposta imune adaptativa (Hoebe et al., 2004).

Segundo Geijtenbeek e Gringhuis (2009), as células dendríticas expressam numerosos receptores de reconhecimento de padrões (PRRs) que interagem com os PAMPs para induzir a expressão de citocinas. Os PRRs incluem os TLRs, assim como não-TLRs, tal como os receptores similares a NOD (NLR, do inglês NOD like receptors), receptores derivados do gene I induzido por ácido retinóico (RIG-I) e receptores de lectina do tipo C (CLRs). Os motivos moleculares associados aos patógenos incluem as mananas na parede celular da levedura e vários peptídeos formilados componentes da parede celular bacteriana, como o FMLP (formil-metionilfenilalanina), lipopolissacarídeos (LPS), lipopeptídeos, peptidoglicanas e acido teicóico (Aderem \& Ulevitch, 2000).

No entanto, estudos recentes têm mostrado que o sistema imune inato tem um grau maior de especificidade do que se pensava anteriormente e que é altamente desenvolvido em sua capacidade de discriminar entre si e patógenos existentes. Essa discriminação se baseia em uma família de receptores evolutivamente conservada, conhecida como TLRs, que têm um 
papel crucial na defesa inicial do hospedeiro contra a invasão dos patógenos. Além disso, o acúmulo de evidências indica que a ativação do sistema imune inato é um pré-requisito para a indução da imunidade adquirida, particularmente para a indução de uma resposta de célula $T$ helper $1\left(T_{h} 1\right)$ (Akira \& Takeda, 2004).

A descoberta da família TLR começou com a identificação de Toll, um receptor que é expresso por células de insetos e foi considerado essencial para o estabelecimento da polaridade dorsoventral durante a embriogênese. Estudos posteriores revelaram que Toll também tem um papel essencial na resposta imune inata do inseto contra infecções a fungos (Akira \& Takeda, 2004).

Os TLRs são glicoproteínas de membrana integral do tipo I, e com base na homologia considerável na região citoplasmática, são membros de uma grande superfamília, que inclui os receptores de interleucina-1 (IL-1Rs), que contém três domínios relacionados a imunoglobulinas em sua região extracelular (Akira \& Takeda, 2004). Os membros da família TLR são caracterizados estruturalmente pela presença de um domínio que apresenta repetição de leucinas (LRR) no seu domínio extracelular (Takeda, Kaisho e Akira, 2003). Os TLRs e IL-1Rs têm uma região conservada de aproximadamente 200 aminoácidos em suas caudas citoplasmáticas, conhecido como domínio de Toll/LL-1R (TIR). Dentro do domínio TIR, as regiões de homologia compreendem três caixas conservadas, cruciais para a sinalização. Notavelmente, apesar da conservação dos domínios LRR, os diferentes TLRs podem reconhecer alguns ligantes não relacionados 
estruturalmente. As localizações subcelulares dos diferentes TLRs correlacionam até certo ponto com os modelos moleculares dos seus ligantes. O TLR1, TLR2 e TLR4 estão localizados na superfície da célula e são recrutados pelos fagossomos após a ativação pelo seu respectivo ligante. Os TLR3, TLR7 e TLR9, expressos em vesículas intracitoplasmáticas, estão envolvidos no reconhecimento das estruturas de ácido nucléico, que não são expressos na superfície da célula alvo (Akira \& Takeda, 2004).

MyD88 foi originalmente isolado como um gene que induz rapidamente a diferenciação da células leucêmicas mielóides do tipo M1 quando estimulado por IL-6. A proteína codificada tem um domínio de morte amino $(\mathrm{N})$ terminal (DD, do inglês death domain), que é separado de seu domínio terminal TIR (C) carboxi-terminal por uma curta sequência. MyD88 foi posteriormente clonado como uma molécula adaptadora que funciona para recrutar IRAK para o complexo IL-1R após a estimulação com IL-1 (Akira \& Takeda, 2004).

A associação entre MyD88 e IRAK é mediada através da interação DD-DD. MyD88 funciona como um adaptador que liga TLRs/L-1Rs com as moléculas de sinalização que têm DDs. A família dos IRAKs é constituída por quatro tipos (IRAK1, IRAK2, IRAK4 e IRAK-M, mostrando padrões distintos de expressão gênica, que têm sido identificados em mamíferos. IRAKs contém um DD N-terminal e um domínio central de serina/treoninaquinase. IRAK1 e IRAK4 têm a atividade de quinase intrínseca, enquanto IRAK2 e IRAK-M não tem atividade quinase detectável. A atividade quinase 
de IRAK1 aumenta fortemente após a estimulação TLR/LL-1R, e seu domínio quinase é essencial para a sinalização através do fator nuclear-kB (NF-kB). No entanto, a atividade quinase em si não é essencial para a sinalização, porque em células deficientes de IRAK1, a superexpressão de um mutantedeficiente da quinase IRAK1 pode induzir fortemente a ativação de NF-kB. Em contrapartida, a superexpressão de IRAK4 não resulta na ativação de NF-kB, mas a expressão de uma IRAK4 mutada no domínio da quinase inibe a ativação de NF-KB mediada por IL-1. Também foi demonstrado que IRAK1 é um substrato direto de IRAK4, mas não o inverso (Akira \& Takeda, 2004).

O termo lectina do tipo C (CLR, do inglês C-type lectin receptor) foi introduzido para distinguir entre as lectinas dependentes de $\mathrm{Ca}^{+2}$ e independentes de $\mathrm{Ca}^{+2}$. Os CLRs mostram um domínio de reconhecimento de carboidrato, que é um módulo estruturalmente compacto que contém motivos de resíduos conservados e determina a especificidade do carboidrato das CLRs (Geijtenbeek e Gringhuis, 2009). As CLRs são uma superfamília de proteínas que possui um ou mais domínios que são homólogos ao domínio de reconhecimento de carboidrato, mas nem sempre se liga às estruturas do carboidrato (Willment e Brown, 2007). Os CLRs existem em duas formas: solúveis e como proteínas transmembrana. Os CLRs podem ser divididos em dois grupos: os CLRs do grupo I, que pertencem à família do receptor de manose, e os CLRs do grupo II, que pertencem à família do receptor de asialoglicoproteína e inclue a lectina tipo C1 associada à célula dendrítica (DC, do inglês dendritic cell) (dectin-1, também conhecida como CLEC7A) e imunoreceptor de DC (DCIR, também 
conhecido como CLEC4A). Os CLRs expressos pelas DCs interagem com patógenos que apresentam estruturas de carboidrato de manose, fucose e glucose. Juntos, esses CLRs reconhecem muitas classes de patógenos humanos; as mananas (oligômeros de manose) fazem parte do reconhecimento de vírus, fungos e micobactérias; as estruturas da fucose são mais especificamente expressadas por certas bactérias e helmintos; e as estruturas de glucana estão presentes nas micobactérias e fungos. $\mathrm{O}$ reconhecimento por CLRs conduz à internalização e degradação dos patógenos, e subsequentemente a apresentação de antígenos (Geijtenbeek e Gringhuis, 2009).

O receptor de manose (MR) (CD206) é um protótipo de proteína transmembrana do tipo I (grupo VI). Possui oito domínios de reconhecimento de carboidrato (CDR), um domínio de repetição de fibronectina tipo II, um domínio rico de cisteína e uma pequena cauda citoplasmática (Willment e Brown, 2007, Hollming et al., 2009). A maioria dos receptores está localizada dentro do caminho endocítico intracelular (McGreal et al, 2005). O MR é expresso por macrófagos, DC e outras células (Figdor et al, 2002), e reconhece alguns organismos, incluindo fungos como a Candida albicans, o Cryptococcus neoformans, o Pneumocystis jiroveci, e outros patógenos tais como vírus e bactérias. O receptor de manose é capaz de se ligar a manose, fucose, $\mathrm{N}$-acetilglicosamina e glucose de maneira dependente de $\mathrm{Ca}^{++}$. Após o reconhecimento do carboidrato, o receptor medeia a internalização do patógeno por fagocitose, conduzindo para a morte intracelular (Hollming et al., 2009). 
Depois de capturar e internalizar o antígeno $(\mathrm{Ag})$ nos órgãos periféricos, as células dendríticas migram aos linfonodos regionais, onde ativam os linfócitos $\mathrm{T}$ naïve. Para a ativação de células $\mathrm{T} C D 8^{+}$os antígenos extracelulares são apresentados em moléculas de MHC classe I, contribuindo para a citotoxicidade exercida por essas células. Os receptores de manose apresentam função auxiliar na apresentação antigênica, visto que manoproteínas são apresentadas de modo mais eficiente que proteínas não manosiladas (Engering et al, 1997; Tan et al, 1997). A despeito disso, diversos fungos que apresentam mananas na parede, como a Candida ssp. e o Criptococo, conseguem desviar a atenção da resposta imunológica e invadir o hospedeiro.

Em resposta a fungos, o MR pode induzir a ativação de NF-kB e a produção de algumas citocinas, incluindo IL-12, IL-8, IL-1ß, IL-6 e fator de estimulação de colônia de granulócitos e macrófagos (GM-CSF) (Willment e Brown, 2007). Adicionalmente, o $M R$ pode realizar uma função imunosupressora por inibir a produção de citocinas inflamatórias quando certos patógenos fúngicos são reconhecidos (Hollming et al., 2009).

A dectina-1 e 2 são membros da família da lectina tipo C, os genes são localizados na região telomérica do cromossomo 6 no camundongo e no cromossomo 12q nos humanos. Tanto a dectina-1 quanto a 2 são proteínas transmembrana glicosiladas do tipo II com um único CDR (Saijo e Iwakura, 2011).

A dectina - 1 pertence ao grupo $\mathrm{V}$ das CLR, possui um único domínio de reconhecimento de carboidratos (CDR) extracelular e uma cauda 
citoplasmática intracelular contendo um motivo ligado à ativação da tirosina (ITAM-like) de 40 aminoácidos (Willment e Brown, 2007, Goodridge et. al., 2009). A dectina-1 é o receptor específico para $\beta$-glucanas e é expresso primariamente por células de origem mielóide, incluindo macrófagos, DCs e neutrófilos em camundongos. Em adição, a dectina-1 tem sido detectada por citometria de fluxo em um subtipo de linfócitos $B$ e $T$, embora sua função nessas células seja desconhecida. Os sinais de dectina-1 contribuem para uma variedade de respostas por macrófagos, DCs e neutrófilos, incluindo fagocitose, explosão oxidativa, degranulação do neutrófilo, morte fúngica e a produção de mediadores lipídicos inflamatórios, e citocinas e quimiocinas que recrutam e coordenam a ativação de outras células imunes (Goodridge et. al., 2009), e induz a ativação de CARD 9 (do inglês Caspase activating recruiting domain member 9) nas DC e macrófagos durante a ativação de macrófagos pelos compostos reativos derivados do oxigênio gerados pela explosão oxidativa. Embora a dectina-1 não seja aparentemente requerida para a defesa contra a $C$. albicans in vivo, inicia de alguma forma defesa contra o Pneumocystis jiroveci. Isto provavelmente ocorre porque as $\beta$ glucanas e quitinas estão localizadas dentro da parede celular fúngica (Saijo et al., 2010). Estudos têm demonstrado que a dectina-1 não se liga a todas as células de leveduras vivas, mas se liga quase que exclusivamente no local dos brotamentos. Isto ocorre em decorrência de um movimento da $\beta$ glucana para outra camada, no local do brotamento, que conduz à quebra da manoproteína com exposição do ligante. Portanto, a dectina-1 reconhece a levedura da $C$. albicans, em algumas condições, mas não reconhece a hifa 
de C. albicans. A dectina-1 liga-se a um grande número de organismos fúngicos, como a C. albicans, o Aspergillus fumigatus, o Pneumocystis jiroveci, o Coccidioides posadasii, o Microsporum audoinii e o Trichophyton rubrum (Hollming, 2009).

A dectina-2 foi originalmente identificada em células de Langerhans específicas, usando a linhagem de célula XS52 ligada a células de Langerhans; sua expressão é também detectada em DCs e macrófagos. Esta molécula tem um CDR contendo um motivo EPN (Glu-Pro-Asn), uma seqüência de aminoácidos com elevada afinidade de ligação a manose dependente de $\mathrm{Ca}^{2+}$, para hifas de $C$. albicans. A dectina-2 possui afinidade específica para a-mananas (Drummond, et al, 2011). A dectina-2 não tem um motivo de sinalização conhecido no domínio citoplasmático, porque a Dectina-2 não tem arginina em sua região transmembrana. Essa arginina é importante na associação com a ITAM (de motivo de ativação de imunotirosina) de moléculas sinalizadoras, tais como o receptor c da cadeia Fc (FcRc) ou a proteína de ativação DNAX de 12 kDa (DAP12), tendo o mecanismo de sinalização permanecido desconhecido por um tempo. No entanto, a Dectina-2 se associa com a cadeia FcRc através do resíduo de arginina no domínio citoplasmático da Dectina-2. A cadeia FcRc é exigida para a função biológica de Dectina2, porque a produção de citocinas foi abolida em camundongos deficientes da cadeia FcRc, apesar de um estímulo de manana (Saijo \& Iwakura, 2011). A dectina-2 liga-se com baixa afinidade a carboidratos com manose, mas são necessárias mais pesquisas para identificar microorganismos 
específicos que o receptor reconhece. Um receptor de dectina-2 fluorescente foi empregado para pesquisar esses microorganismos, mas não se conseguiu evidenciar bactérias (Staphylococcus aureus, Streptococcus pyogenes do grupo A, Pseudomonas aeruginosa, ou Escherichia coll), e nem leveduras de $C$. albicans ligadas à dectina-2. Entretanto, a dectina-2 liga-se a hifas de C. albicans. Este tipo de ligação também foi notado entre dectina2 e filamentos, mas não com a forma conidial dos dermatófitos $M$. audouinii e T. rubrum. Essa ligação foi completamente bloqueada por mananas, mas não por $\beta$-glucanas, indicando assim que o ligante de hifas de dectina-2 é diferente do ligante conidial da dectina-1. O caminho de sinalização de Dectina-2 pode ativar um mecanismo de defesa imune, incluindo a potencialização da secreção de TNF- $\alpha$ e o antagonista do receptor da IL1(Hollming, 2009). Saijo e colaboradores (2010) mostraram a importância de Dectina-2 na diferenciação de células $T_{h} 17$, sob infecção com a forma de levedura da C. albicans. Portanto, a sinalização de Dectina-1 e Dectina-2 induzem preferencialmente a diferenciação de células $T_{h} 17$ (Saijo e Iwakura, 2011).

Mincle (do inglês Macrophage-inducible C-type lectin) - originalmente foi identificada como um alvo transcripcional da NF-IL6 (também chamado de $\mathrm{C} / \mathrm{EBP} \beta$ ) em macrófagos. Mincle é um membro da família de Dectina-2 dos CLRs, é um receptor não fagocítico, e sua expressão em macrófagos é controlada por estímulos inflamatórios. O ligante de fungos para Mincle não está bem definido, no entanto, estudos recentes utilizando microarranjos (microarrays) e estudos mutacionais sugeriram que é um ligante de manose 
(Drummond, et. al, 2011). Mincle é um tipo de proteína de transmembrana tipo II também conhecido como Clec4e ou Clecsf9 principalmente expresso em células mielóides, tais como macrófagos e neutrófilos e possui um domínio de reconhecimento de carboidratos simples (CRD) na região extracelular. O nível de expressão de Mincle na condição de repouso é muito baixa, no entanto, é fortemente induzida após a exposição a vários estímulos, como citocinas inflamatórias e ligantes de TLR. Mincle está associado a um receptor Fc $\gamma$ (FcR $\gamma$ ) que contém um motivo ITAM com um resíduo de carga positiva na região transmembrana. A ativação de Mincle leva a uma cascata de sinalização que começa com a fosforilação de resíduos de tirosina do ITAM por tirosina-quinases da família Src, seguido pelo recrutamento e ativação de Syk (de spleen-tyrosine kinase). Syk então ativa uma cascata de sinalização através de CARD9 (Ruland, 2008), e este evento leva à indução de citocinas inflamatórias, tais como TNF- $\alpha$, MIP-2 (CXCL2), KC (CXCL1) e IL-6. Portanto, Mincle pode atuar como um receptor de ativação induzido por certo ligante. O FcR- $\gamma$ acoplado à Dectina - 2 reconhece C. albicans, M. audouinii e T. rubrum (Miyake et, al, 2010).

Embora Yamasaki et al. (2009) não tenha demonstrado que Mincle induza imunidade adaptativa durante respostas antifúngicas, esta tem sido observada durante respostas anti-micobacterianas. Mincle se liga a um componente-chave da micobactéria, trehalose-6,6'- dimicolato (TDM, também conhecido como fator corda), bem como um derivado sintético (trehalose-6, 6-dibehenate, TDB). Estes compostos têm sido investigados por sua atividade adjuvante e foi recentemente demonstrado que Mincle foi o 
receptor-chave envolvido na indução de citocinas e óxido nítrico em resposta a TDM / TDB (Drummond, et al., 2011).

A proteína de fusão recombinante de Mincle-Fc se liga a glicolipídeos. A ablação genética de Mincle abole a ativação de macrófagos por TDM/TDB e a indução de células $T$ específicas em resposta a uma subunidade da vacina de tuberculose. A falta de Mincle ou FcR- $\gamma$ em macrófagos foi prejudicial na resposta inflamatória ao BCG (Mycobacterium bovis, bacilo de Calmette-Guérin), assim como a Chlamydia e a outros patógenos (Schoenen et al., 2010).

A combinação de citocinas produzidas pelas DCs a partir da sinalização por Dectina-1/CARD9 difere profundamente do perfil de citocinas induzidas por ativadores clássicos como TLR/MyD88. A ativação de Dectina1/CARD9 induz quantidades consideráveis de IL-2, IL-6, IL-10, TNF- $\alpha$ e IL23, mas pouca IL-12. Esse efeito diferencial de ativação das células tem consequências funcionais para a diferenciação subsequente de células $T$. Considerando que os TLR das DCs estimuladas agem principalmente em respostas de células $T$, via Th1, a ativação de Dectina-1/CARD9 em DCs instrui a diferenciação de células Th1 produtoras de IFN- $\gamma$ e geração de IL17, o qual produz células Th17. No contexto da imunidade a fungos, isto pode ser importante, uma vez que a IL-17 tem sido associada à resistência contra Candida albicans, e que CARD9 ativa a sinalização direcionando as células T específicas para a via Th-17, após infecção fúngica pela Candida albicans em vivo (Ruland, 2008). 
Além desses fatores, outros como o interferon-gama (IFN-ү), o fator de necrose tumoral (TNF) e a opsonização pelo sistema complemento facilitam a fagocitose (Bullock \& Wong, 1995).

As células "natural killer" (NK), linha de frente da resposta celular inata, respondem de maneira inespecífica a estímulos como vírus, neoplasias e fungos que tenham atravessado as barreiras epiteliais, secretando citocinas como os fatores de necrose tumoral alfa e beta (TNF- $\alpha$ e TNF- $\beta$ ), o interferon gama (IFN- $\gamma$ ) e o fator estimulador de colônias de granulócitos e monócitos (GM-CSF), que ativam e induzem diferenciação dos monócitos a macrófagos e também direcionam a resposta imunológica por meio da ativação dos linfócitos T CD4 ${ }^{+}$ou CD8 ${ }^{+}$. (Seaman, 1996).

Os linfócitos B atuam sobretudo na defesa a bactérias capsuladas e vírus, podendo, todavia auxiliar na opsonização de fungos. Assim, pacientes com dermatofitose disseminada usualmente apresentam altos títulos de anticorpos dirigidos ao fungo. Todavia, o papel desses anticorpos ainda não é bem compreendido, especialmente tendo-se em vista as evidências de que os anticorpos não são necessários para a morte de células fúngicas (Woodfolk et al, 1996, Weitzman \& Summerbell, 1995).

Os anticorpos da classe IgM ocorrem nas infecções agudas e crônicas, enquanto que das classes $\lg G$, $\lg A$ e $\lg E$ somente são observadas em infecções crônicas. É importante ressaltar que somente os anticorpos da classe IgE específicos para $T$. rubrum demonstraram especificidade, não sendo encontrados em controles, nem em pacientes com infecção aguda 
provocada por outras espécies de dermatófitos (Svejgaard \& Lowenstein, 1985).

A imunidade mediada por células assume papel importante na defesa do hospedeiro contra dermatófitos. Essa asserção baseia-se nos testes cutâneos in vivo e também nas avaliações de linfócitos in vitro. (Grappel et al., 1974, Svejgaard, 1986). Os resultados obtidos em testes cutâneos com antígenos de dermatófitos padronizados não são bem definidos em pessoas infectadas naturalmente. Os pacientes com infecção aguda geralmente apresentam reação do tipo tardio, enquanto que as reações imediatas ou a ausência de reação ocorrem em pacientes infectados cronicamente (Almeida, 2008).

A melhor técnica para avaliar a resposta imune celular in vitro é considerada a proliferação de linfócitos, apresentando boa correlação com os testes cutâneos de hipersensibilidade tardia. Além disso, a resposta está relacionada à gravidade da lesão em pacientes com dermatofitose aguda, persistindo no mínimo por seis meses. No entanto, pacientes cronicamente infectados apresentam respostas variáveis e inclusive flutuações na resposta individual ao antígeno do dermatófito. Além disso, existe grande dificuldade na obtenção de extratos antigênicos adequados para avaliação da resposta imune celular (Svejgaard, 1986).

As variações das respostas de proliferação de pacientes e indivíduos sadios em geral devem-se não somente aos antígenos, como aos peptídeos integrantes de sua estrutura. Dentre esses, o peptídeo YIIDTGIDID parece possuir uma maior capacidade de indução de proliferação celular em 
indivíduos com hipersensibilidade tardia, enquanto, indivíduos com sensibilidade imediata apresentam proliferação diante de todos os peptídeos estudados. (Woodfolk et al., 2000). Foi sugerido que a resposta proliferativa das células $\mathrm{T}$ a este peptídeo deveria promover o desenvolvimento da hipersensibilidade tardia, prevenindo sua progressão para dermatofitose crônica. Neste caso, a indução da resposta $T h_{1}$ ao peptídeo, caracterizada pela síntese de IL-2, IFN- $\gamma$ e TNF e oposta à resposta $T_{2}$, que se caracteriza pela síntese de IL-4, IL-5, IL-10 e IL-13, pode ser necessária para conferir esta proteção. (Woodfolk et al., 2001). As citocinas $\mathrm{Th}_{1}$ induzem respostas celulares importantes que são centrais para a eliminação de patógenos intracelulares (Heinzel et al, 1989; Scott et al, 1989; Sher et al, 1992). As citocinas $T_{2}$ induzem respostas distintas, principalmente a indução de $\lg E$ e a eosinofilia. Essas respostas $\mathrm{Th}_{2}$ são características das helmintíases, das doenças atópicas e de infecções não controladas por patógenos intracelulares como a leishmaniose visceral e a lepra lepromatosa. (Maggi et al, 1992). 


\section{JUSTIFICATIVA}

Devido ao fato de havermos encontrado deficiência do receptor de manose (CD206) e de citocinas de padrão Th1 (IL-2 e IFN- $\gamma$ ) no sobrenadante de cultura de células mononucleares induzido pela ativação antígeno-específica de pacientes portadores de candidíase mucocutânea crônica (Moraes-Vasconcelos \& Duarte, 1998), a proposta deste estudo foi pesquisar nos pacientes portadores de dermatofitoses extensas o perfil imunológico, quantificando a capacidade linfoproliferativa e a síntese de citocinas, buscando uma melhor compreensão sobre os distúrbios imunológicos envolvidos nas dermatofitoses disseminadas.

O modelo estudado foi de pacientes portadores de dermatofitoses extensas, que constituem um grupo bastante importante de pacientes dos quais pouco se sabe e pouco se faz quanto ao tratamento específico da doença. 


\section{OBJETIVOS}

\subsection{Objetivo geral:}

- Avaliar a resposta imunológica celular específica ao Trichophyton rubrum em pacientes portadores de dermatofitoses extensas.

\subsection{Objetivos específicos:}

- Obter um extrato antigênico protéico após cultivo e purificação de Trichophyton rubrum, e avaliar sua capacidade de indução de resposta celular "in vitro", por meio da quantificação da resposta linfoproliferativa de células mononucleares do sangue periférico, comparando com outros estímulos inespecíficos (Fitohemaglutinina [PHA], monoclonal anti-CD3 [OKT3], Pokeweed [PWM]), e específicos por antígenos não relacionados Candida ssp. (CMA).

- Quantificar a resposta imune celular "in vitro", por meio da quantificação da resposta proliferativa de células mononucleares do sangue periférico de indivíduos sadios do grupo controle e do grupo de pacientes portadores de dermatofitose extensa ao peptídeo YIIDTGIDID do fungo T. rubrum.

- Quantificar a síntese e secreção de citocinas dos padrões Th1 (IFN-gama e IL-12) e Th2 (IL-4 e IL-10) por células mononucleares de sangue periférico estimulado por PHA, CMA a pelo peptídeo YIIDTGIDID do fungo T. rubrum. 


\section{CASUÍSTICA}

\subsection{Pacientes e Grupo Controle.}

Foram incluídos neste estudo pacientes portadores de dermatofitoses extensas sem qualquer outro processo infeccioso relevante, que já vêm sendo acompanhados no ambulatório de imunodeficiências primárias (ADEE-3003) do Departamento de Dermatologia do Hospital das Clínicas da Faculdade de Medicina da USP (HCFMUSP) (Tabela 2). Esses pacientes foram avaliados quanto à existência de qualquer doença de base ou uso de medicação imunossupressora, que constituíram critérios de exclusão.

I. Menores de 18 anos de idade;

II. Gestantes;

III. Imunodeficiência primária ou secundária conhecida;

IV. Dermatofitoses causadas por outros dermatófitos, que não o Trichophyton rubrum.

Os exames laboratoriais de rotina incluíram hemograma, glicemia, uremia, ácido úrico, culturas para microorganismos em caso de suspeita de infecção e testes imunológicos como imunoglobulinas, complemento, sorologias para pesquisa de resposta imunológica anamnéstica e pesquisa de auto-anticorpos. Em decorrência da necessidade de diagnóstico diferencial com diversas imunodeficiências, os pacientes foram selecionados após exclusão de outras imunodeficiências primárias, por meio de uma série de exames laboratoriais específicos, como ampla imunofenotipagem por 
citometria de fluxo, quantificação de enzimas como a peroxidase de neutrófilos e a Adenosina Deaminase, entre diversos outros exames.

Os ensaios imunológicos específicos foram realizados como descrito a seguir. Os pacientes foram avaliados a cada oito semanas, tendo livre acesso à clínica na eventualidade de qualquer sintoma clínico.

O grupo controle foi constituído de indivíduos adultos sadios, sem história passada de dermatofitoses graves e sem diagnóstico atual de infecção por T. rubrum (Tabela 1). O material (sangue periférico) foi coletado na coleta de rotina do seguimento dos pacientes. O protocolo foi avaliado e aprovado pela Comissão de Ética para Avaliação de Projetos de Pesquisa (CAPPesq) do Hospital das Clínicas da Faculdade de Medicina da Universidade de São Paulo (USP), sob o número de processo: 855/00. 
Tabela 1: Relação de controles positivos que algum momento da vida apresentaram micose

\begin{tabular}{|c|c|c|c|}
\hline Indivíduo & Idade & Sexo & Local de Nascimento \\
\hline $\mathrm{I}$ & 47 & $\mathrm{M}$ & Rio de Janeiro -RJ \\
\hline II & 42 & M & São Paulo - SP \\
\hline III & 44 & M & São Paulo - SP \\
\hline IV & 48 & M & São Paulo - SP \\
\hline $\mathrm{V}$ & 34 & M & São Paulo - SP \\
\hline $\mathrm{VI}$ & 49 & M & Califórnia - EUA \\
\hline VII & 25 & $\mathrm{~F}$ & São Paulo - SP \\
\hline VIII & 26 & M & São Paulo - SP \\
\hline IX & 26 & $\mathrm{~F}$ & São Paulo - SP \\
\hline$x$ & 23 & $\mathrm{~F}$ & São Paulo - SP \\
\hline $\mathrm{XI}$ & 28 & M & São Paulo - SP \\
\hline XII & 33 & M & São Paulo - SP \\
\hline XIII & 24 & $\mathrm{~F}$ & Jundiaí - SP \\
\hline XIV & 27 & M & São Paulo - SP \\
\hline $\mathrm{XV}$ & 21 & M & São Paulo - SP \\
\hline $\mathrm{XVI}$ & 29 & $\mathrm{~F}$ & Rio de Janeiro - RJ \\
\hline $\mathrm{XVII}$ & 32 & $F$ & São Paulo - SP \\
\hline XVIII & 27 & $\mathrm{~F}$ & São Paulo - SP \\
\hline$X I X$ & 25 & $\mathrm{~F}$ & Rio Grande do Sul - RS \\
\hline$X X$ & 30 & $\mathrm{~F}$ & Bauru - SP \\
\hline
\end{tabular}

Média de idade do grupo controle: 32 anos, sendo 11 indivíduos do sexo masculino e 9 do sexo feminino. 
Tabela 2: Relação de pacientes com dermatofitose causada por Trichophyton rubrum

\begin{tabular}{|c|c|c|c|c|c|}
\hline Indivíduo & Idade & Idade Diagnóstico & Sexo & Diagnóstico & Local Nascimento \\
\hline $\mathrm{I}$ & 76 & 76 & $\mathrm{~F}$ & Dermatofitose Extensa & Portugal - POR \\
\hline II & 17 & 17 & $\mathrm{~F}$ & Tinea de Repetição & São Paulo - SP \\
\hline III & 42 & 42 & M & Dermatofitose Extensa & Jequié - BA \\
\hline IV & 65 & 61 & $\mathrm{~F}$ & Dermatofitose Recorrente & São Paulo - SP \\
\hline V & 74 & 72 & $\mathrm{M}$ & Dermatofitose Crônica & Araçatuba - SP \\
\hline VI & 19 & 18 & $\mathrm{~F}$ & Dermatofitose Extensa & São Paulo - SP \\
\hline VII & 15 & 14 & $\mathrm{~F}$ & Dermatofitose Extensa & Osasco - SP \\
\hline VIII & 57 & 49 & $\mathrm{~F}$ & Dermatofitose Extensa & São Paulo - SP \\
\hline IX & 9 & 9 & M & Dermatofitose Extensa & São Paulo - SP \\
\hline$x$ & 14 & 7 & M & Dermatofitose Extensa & São Paulo - SP \\
\hline$X I$ & 55 & 46 & $\mathrm{~F}$ & Dermatofitose Extensa & Jequié - BA \\
\hline & & & & & Itapecerica da Serra \\
\hline XII & 51 & 42 & M & Dermatofitose Extensa & $-\mathrm{SP}$ \\
\hline XIII & 31 & 30 & $\mathrm{~F}$ & Dermatofitose Crônica recorrente & São Paulo - SP \\
\hline XIV & 31 & 31 & $\mathrm{~F}$ & Dermatofitose Extensa & Rio Casca - MG \\
\hline$X V$ & 12 & 13 & M & Onicomicose/Dermatofitose & São Paulo - SP \\
\hline $\mathrm{XVI}$ & 58 & 53 & M & Dermatofitose Extensa & Solanea - PB \\
\hline XVII & 56 & 53 & $\mathrm{~F}$ & Dermatofitose Extensa/Onicomicose & Guaraciaba - MG \\
\hline XVIII & 45 & 41 & $\mathrm{~F}$ & Dermatofitose Extensa & Mongaguá - SP \\
\hline XIX & 49 & 49 & $M$ & Dermatofitose Extensa & São Paulo - SP \\
\hline$X X$ & 37 & 37 & M & Dermatofitose Extensa & Belo Horizonte - MG \\
\hline
\end{tabular}




\section{Materiais e Métodos}

\subsection{Obtenção de antígeno protéico do Trichophyton}

\section{rubrum}

Sabe-se que a obtenção de soluções antigênicas protéicas a partir de fungos dermatófitos esbarra na dificuldade de separar as proteínas das estruturas lipídicas e glicídicas presentes na parede celular. Disso decorre o fato de estudos anteriores, alguns conduzidos em nosso laboratório (Moraes-Vasconcelos \& Duarte, 1998), demonstrarem a baixa resposta de linfócitos $T$ aos extratos protéicos dos dermatófitos (genericamente denominados tricofitinas). Esses achados levaram a procura por novas técnicas de obtenção de extratos antigênicos enriquecidos em proteínas que estimulassem melhor as células $\mathrm{T}$ de indivíduos sensibilizados. Com o objetivo de se obter um extrato de T.rubrum com maior concentração de proteína, aumentando desta forma o seu potencial imunogênico e capacidade de proliferação de linfócitos, decidimos nos basear no trabalho realizado por Souza \& Gambale, 1993.

A amostra fúngica foi obtida a partir da micoteca do Laboratório de Micologia do Instituto de Medicina Tropical, e o fungo foi cultivado em meio de Czapeck modificado por Yunginger (Souza \& Gambale, 1993). 


\subsubsection{Meio de Czapeck modificado}

$\begin{array}{ll}\mathrm{NaNO}_{3} & 3,0 \mathrm{~g} \\ \mathrm{KsHPO}_{4} & 1,0 \mathrm{~g} \\ \mathrm{MgSO}_{4} & 0,5 \mathrm{~g} \\ \mathrm{KCl} & 0,5 \mathrm{~g} \\ \mathrm{FeSO}_{4} & 0,01 \mathrm{~g} \\ \text { Maltose } & 15,0 \mathrm{~g} \\ \text { Dextrose } & 15,0 \mathrm{~g} \\ \text { Triptona } & 10,0 \mathrm{~g} \\ \text { Água destilada } & 1.000 \mathrm{~mL}\end{array}$

Dissolveram-se os ingredientes em água destilada aquecendo em banhomaria. Esterilizou-se a $120^{\circ} \mathrm{C}$ por 20 minutos e ajustou-se o pH entre 6,8 a 7,0 .

\subsubsection{Extração do antígeno com líquido de Coca}

A tricofitina foi extraída dos fungos em função do crescimento das culturas com líquido de Coca. $O$ cultivo de $T$. rubrum foi filtrado e subsequentemente lavado três vezes em água destilada estéril e três vezes em álcool $96^{\circ} \mathrm{GL}$. A massa fúngica foi seca em estufa a $37^{\circ} \mathrm{C}$ por 48 horas, triturada em Gral e pesada em balança analítica. O líquido de Coca ( $\mathrm{NaCl}$ : 
concentração peso-volume de $10 \%$ e o preparado mantido a $4^{\circ} \mathrm{C}$ durante 7 dias. A seguir foi centrifugado a $1900 \times \mathrm{G}$, o sedimento desprezado e o extrato liofilizado (Souza \& Gambale, 1993).

\subsubsection{Dosagem de Proteínas e Açúcares}

As concentrações de proteínas do extrato foram quantificadas pelos métodos de Bradford e Lowry, e açúcares pelo método de Du Bois (Souza \& Gambale, 1993).

\subsubsection{Eletroforese em gel de poliacrilamida contendo dodecil- sulfato de sódio (SDS-PAGE)}

A eletroforese vertical em gel de poliacrilamida contendo dodecil sulfato de sódio (SDS-PAGE) (Sigma-Aldrich Co., St. Louis, Missouri, USA) foi realizada segundo metodologia proposta por Laemmli (1970), sendo o gel de separação linear a 10\% e Gel de empilhamento de acrilamida com espessura de 1,0 mm, Mini Trans - Blot ${ }^{\circledR}$ Cell (Bio-Rad Laboratories, Inc., Hercules, California, USA).

As amostras do Extrato de Trichophyton rubrum foram desnaturadas a 95드 por 5 minutos em tampão de ruptura (10\% w/v SDS (Sigma - EUA), $1 \mathrm{M}$ Tris- $\mathrm{HCl}$ (Gibco - EUA) pH 6.8, Glicerol (Invitrogen - EUA), azul de bromofenol (Sigma - EUA) e água deionizada, sendo aplicados $25 \mu \mathrm{l}$ de cada amostra do extrato por orifício para visualização do padrão protéico de migração. 
O primeiro gel de poliacrilamida (Gibco - EUA) foi feito diluindo-se a bis-acrilamida (Invitrogen - EUA) a $30 \%$, Tris- $\mathrm{HCl}$ em $\mathrm{pH} 8.8$, água deionizada, adicionando-se 10\% de SDS, persulfato de amônia (GE - EUA) e TEMED (GE - EUA). Colocou-se butanol para evitar a formação de bolhas de ar, deixando-se polimerizar por 30 minutos. Após esse tempo, a placa de vidro foi lavada 5X com água deionizada, para retirar todo o butanol (Merck Alemanha).

O segundo gel foi feito adicionado bis-acrilamida $30 \%$, Tris- $\mathrm{HCl}$ em $\mathrm{pH}$ 6.8 e água deionizada, adicionou-se 10\% SDS, persulfato de amônia e TEMED, homogeneizou-se bem e colocou-se na placa de vidro; após esse procedimento o pente foi colocado, deixando-se por 2 horas para polimerizar.

Após a polimerização, retirou-se o pente, colocou-se o tampão de corrida, adicionando o padrão de peso molecular (PPM) e as amostras diluídas em tampão de amostra.

A corrida eletroforética foi realizada com voltagem de $80 \mathrm{~V}$, corrente de $16 \mathrm{~mA}$ por 1 hora e 30 minutos para percorrer o gel de empilhamento, empregando fonte Power Pac Basic (Bio-Rad Laboratories, Inc., Hercules, California, USA).

Para visualização das bandas protéicas ao término da corrida eletroforética, o gel foi corado pelo azul brilhante de Coomassie (SigmaAldrich Co., St. Louis, Missouri, USA)por quinze minutos. Retirou-se o gel e colocou-se no descorante por 1 hora e trinta minutos, trocando-se o meio e deixando-se por 18 horas sob agitação contínua. 
As soluções, tampões e corantes utilizados na técnica de eletroforese em gel de poliacrilamida encontram-se no ANEXO C.

\subsection{Avaliação do Fenótipo das Células por Citometria de} Fluxo

A avaliação das moléculas de superfície das células imunocompetentes foi realizada por citometria de fluxo, empregando os seguintes anticorpos monoclonais, conjugados a FITC, PE e PE-Cy5: CD3, CD4 e CD8 para a identificação de linfócitos T. Foi realizada também a identificação de células B pela expressão de CD19 e/ou CD20, e de células NK pela tripla marcação CD3-CD16+CD56+, e avaliação da expressão de CD206 (receptor de manose de monócitos) nessa população, com os respectivos controles isotípicos. Para a marcação, $100 \mu \mathrm{L}$ da suspensão celular foram incubados durante 20 minutos com $10 \mu \mathrm{L}$ dos anticorpos monoclonais. Ao término da incubação, as hemácias foram lisadas em uma solução de lise (Immunoprep, Beckman Coulter, EUA) em um dispositivo automatizado (Multi-Q-Prep, Coulter, EUA). A seguir, as células foram lavadas duas vezes com $2 \mathrm{~mL}$ de PBS ( $\mathrm{pH} 7,4)$ suplementado com azida sódica a 0,02\% e 0,02\% de albumina bovina (PBS-azida), durante 2 minutos a 400G. O botão celular foi ressuspenso em $400 \mu \mathrm{L}$ de PBS-paraformaldeído a $4 \%$ e submetido à aquisição e análise por citometria de fluxo. Para a análise, foram adquiridos 20.000 eventos em cada gate selecionado, em um citômetro Coulter EpicsXL-MCL (Beckman Coulter, EUA), obtendo-se dessa forma valores percentuais das sub-populações de linfócitos. Os valores absolutos foram 
obtidos pelo produto dos linfócitos totais de leucograma realizado concomitantemente em contador de células Cell-Dyn 1400 (Abbott, EUA).

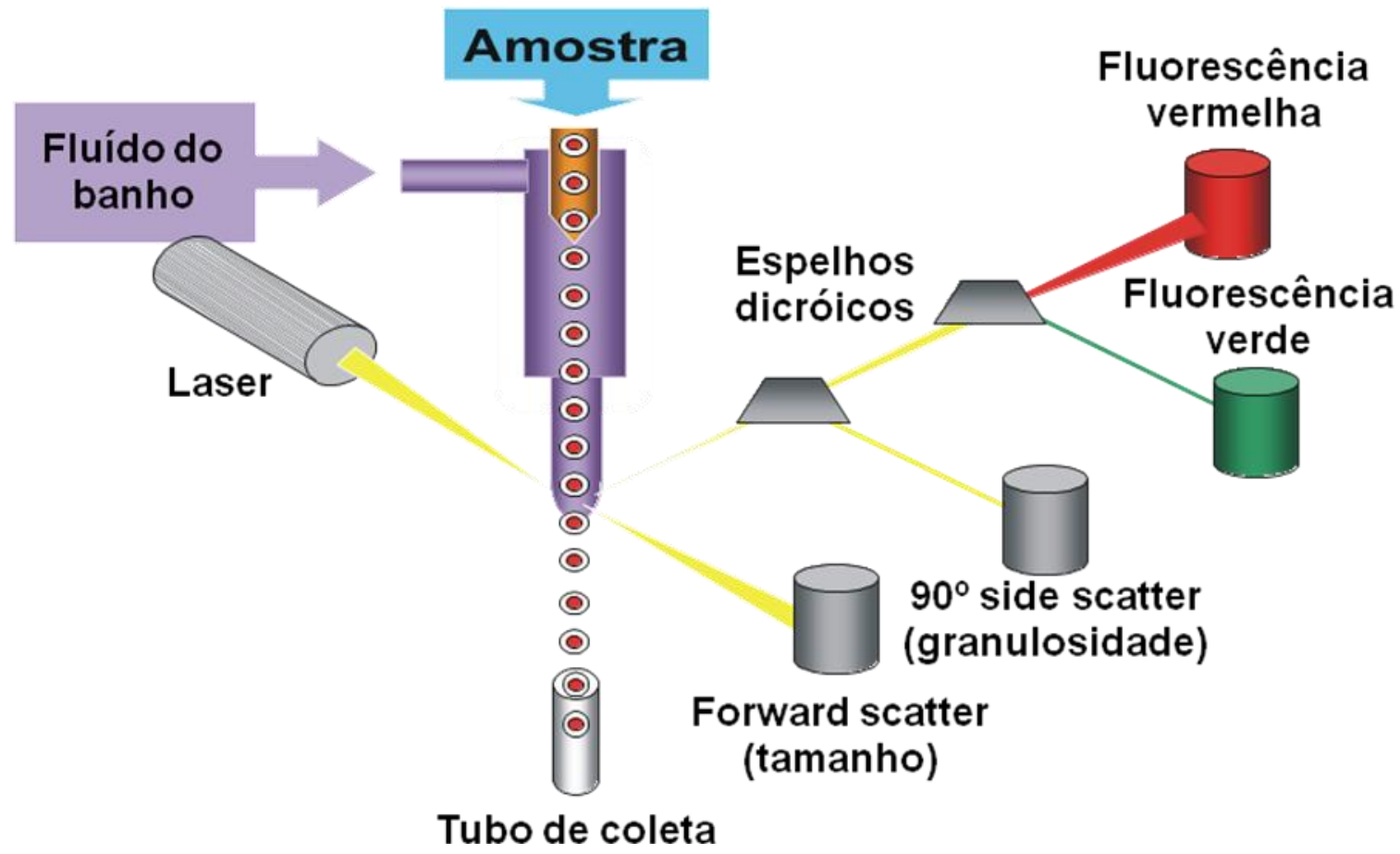

Figura 2 - Esquema genérico de um citômetro de fluxo, mostrando a fonte de luz (laser), a câmara de fluxo, os fotomultiplicadores (sensores) e os espelhos passa-banda dicróicos.
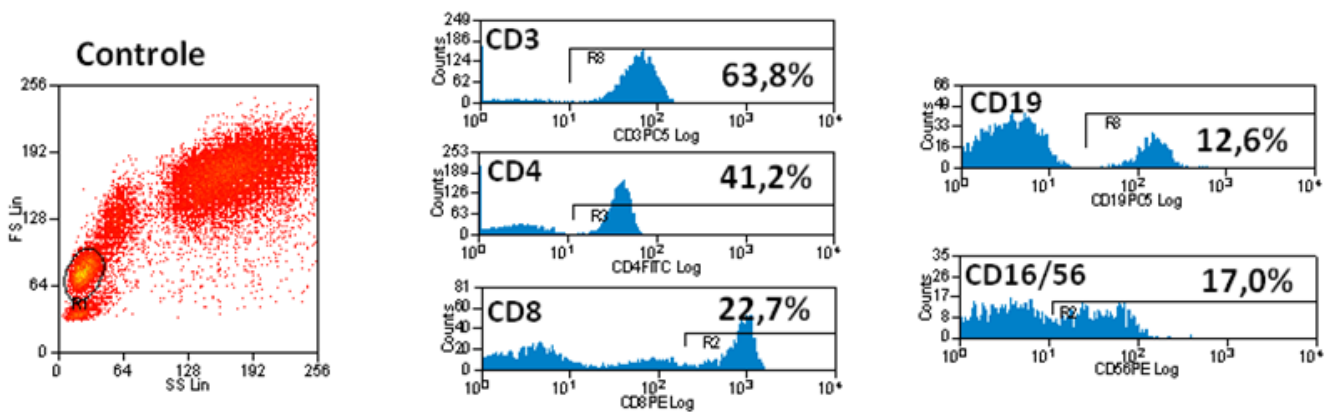

Figura 3 - Quantificação de linfócitos T, B e NK de controles e pacientes por citometria de fluxo com os anticorpos monoclonais anti-CD3, anti-CD4, anti-CD8, anti-CD19 e antiCD16/CD56. 


\subsection{Separação das células mononucleares}

As células mononucleares do sangue periférico (PBMC) foram obtidas através da coleta de $20 \mathrm{~mL}$ de sangue periférico em tubo heparinizado, diluído em solução salina isotônica estéril em proporção 1:1 (volume a volume) e posteriormente passado para um tubo cônico contendo Ficoll (Sigma-Aldrich, Saint Louis, EUA) Hypaque (GE Healthcare, Brasil) (FicollHypaque) na proporção 1:3, separadas por meio de fracionamento em gradiente de densidade 1.076 (Böyum, 1968), sendo centrifugada a 867G por 20 minutos. Após o período de centrifugação, o anel composto por células mononucleares foi aspirado e passado para um tubo cônico contendo meio enriquecido estéril (RPMI-1640 com 10\% soro humano AB), e foram lavadas duas vezes em centrífuga a $400 \times \mathrm{g}$ por dez minutos. $\mathrm{O}$ sobrenadante foi retirado e as células foram ressuspensas em $1 \mathrm{~mL}$ do meio enriquecido, retirando-se uma quantidade de células que foram contadas no contador de células Cell Dyn e avaliou-se a viabilidade celular no hemocitômetro (câmara de Neubauer) corando-as com azul de tripan. A concentração celular foi então ajustada para $2 \times 10^{6}$ células $/ \mathrm{mL}$ para utilização posterior. As soluções e tampões estão descritos no ANEXO A. 


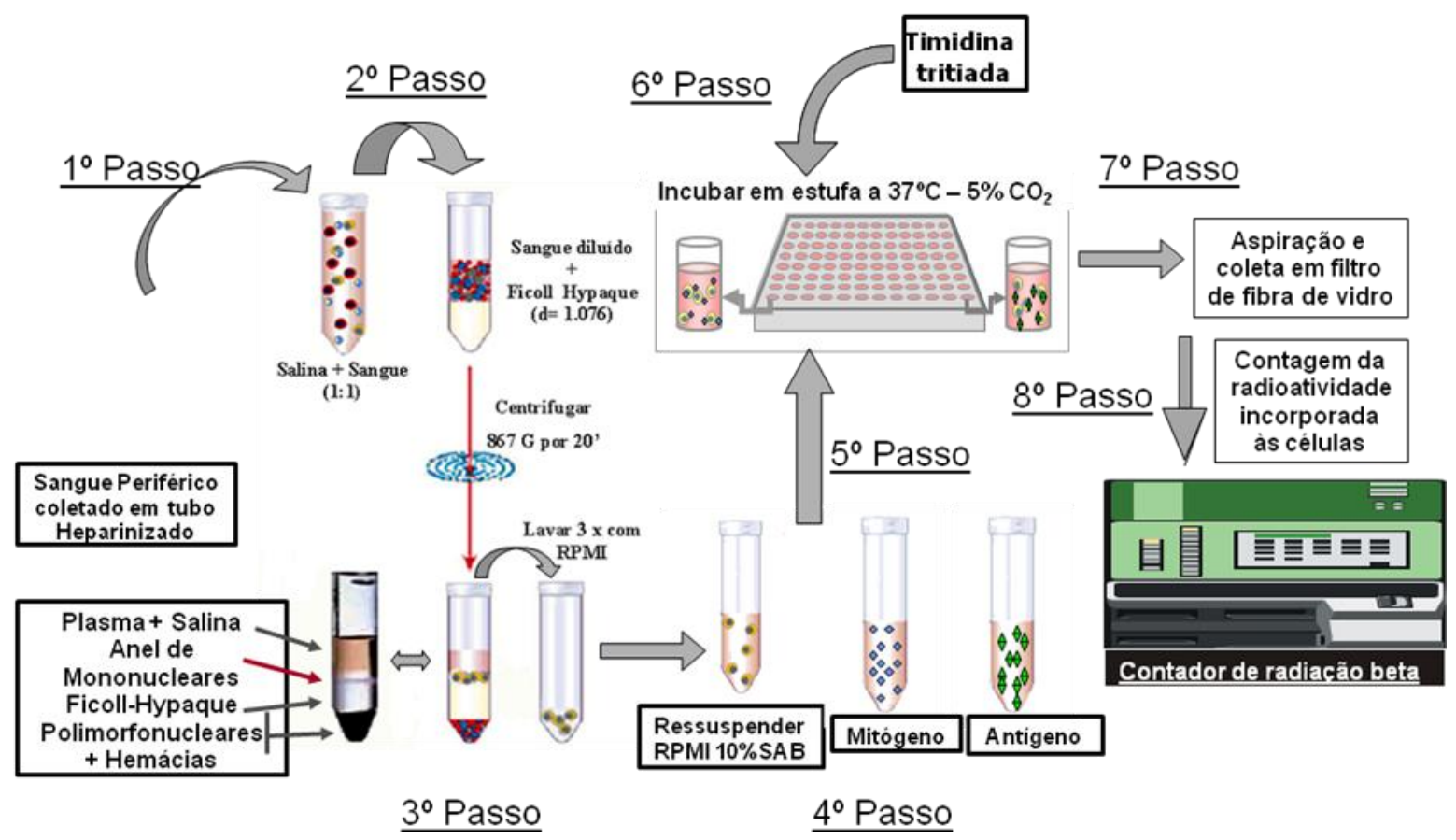

Figura 4 - Esquema explicando a técnica de separação de células por gradiente de densidade de Ficoll-Hypaque e cultura de células mononucleares de sangue periférico com estímulos inespecíficos (mitógenos) e específicos (antígenos). A avaliação da resposta proliferativa é obtida por meio da incorporação de timidina triciada ao DNA das células em divisão celular.

\subsection{Cultura e estimulação das células}

As células mononucleares dos pacientes e dos controles foram cultivadas em microplacas de fundo plano de 96 orifícios, a uma densidade de $1 \times 10^{6} / \mathrm{mL}$ em meio RPMI-1640 enriquecido com $10 \%$ de soro humano AB, L-glutamina e estimuladas pelo mitógeno Pokeweed (PWM, SigmaAldrich, Saint Louis, EUA) na concentração de $5 \mu \mathrm{g} / \mathrm{mL}$, utilizado como controle positivo da resposta linfoproliferativa, por antígeno metabólico de Candida sp. (CMA, Pasteur-BioRad, França) na concentração de $5 \mu \mathrm{g} / \mathrm{mL}$, pelo extrato de T. rubrum $(5 \mu \mathrm{g} / \mathrm{ml}, 10 \mu \mathrm{g} / \mathrm{ml}, 20 \mu \mathrm{g} / \mathrm{ml}$ e $40 \mu \mathrm{g} / \mathrm{ml})$ inicialmente, e pelo peptídeo do T. rubrum (YIIDTGIDID) a partir da concentração mãe de 
750mM nas diluições de 1/6,25; 1/12,5; 1/25; 1/50 (Invitrogen Corporation, EUA), durante seis dias, em estufa a $37^{\circ} \mathrm{C}$ e $5 \%$ de $\mathrm{CO}_{2}$. Cerca de 18 horas antes do tempo previsto para o término do cultivo (144 horas), foram adicionados $3,7 \times 10^{-2} \mathrm{mBq}(1 \mu \mathrm{Ci})$ de timidina tritiada $\left({ }_{3} \mathrm{H}-\mathrm{TdR}\right)$ (Amersham International, UK), diluída em meio de cultura (RPMI-1640). Ao final da incubação as células foram coletadas em membrana de fibra de vidro (Wallac) através de um coletor de células (Cell harvester, Perkin Elmer, EUA). Depois de secos, os níveis do radioisótopo incorporado na membrana foram quantificados com o auxílio de um contador de radiação beta (Wallac Beta Plate 1205, Maryland, EUA). Os resultados das culturas foram apresentados por média aritméticas das quadriplicatas dos poços estimulados, menos a medida aritmética das quadriplicatas não estimuladas expressos como índice de estimulação (IE).

\subsection{Dosagem de Citocinas (IL-4, IL-10, IL-12 e IFN-Y)}

As dosagens das citocinas (IL-4, IL-10, IL-12 e IFN- $y$ ) foram realizadas por método imunoenzimático (ELISA) de captura nos sobrenadantes de culturas realizadas simultaneamente às acima descritas, estimuladas por antígenos específicos e por mitógenos, conforme técnica descrita pelo fabricante (Endogen - Pierce Biotechnology Inc, EUA). A absorbância foi obtida em um leitor de ELISA em comprimento de onda de 450nm e uma curva padrão construída a partir das citocinas recombinantes para interpolar os valores obtidos pelas amostras. A sensibilidade do conjunto de reagentes utilizado, segundo especificações dos fabricantes, foi 
$<6 \mathrm{pg} / \mathrm{mL}$ para todas as citocinas testadas. Os protocolos podem ser descritos sucintamente da seguinte maneira:

O Anticorpo de captura para a IL-4 foi diluído a $5 \mu \mathrm{g} / \mathrm{mL}$, e para a IL-10, IL-12 e IFN- $\gamma$ a $2,5 \mu \mathrm{g} / \mathrm{mL}$ em PBS. Adicionaram-se $50 \mu \mathrm{L}$ aos orifícios de uma microplaca para ELISA (High-binding) de 96 orifícios, cobrindo-se a placa e incubando-se durante 18 horas a $4^{\circ} \mathrm{C}$. A seguir, a placa foi lavada cinco vezes com Tris/ $\mathrm{HCl} 50 \mathrm{mM}$. Para cada lavagem, os orifícios foram preenchidos com Tris/ $\mathrm{HCl}$, deixando-se em repouso por pelo menos um minuto antes de aspirar ou desprezar. Deitaram-se as placas viradas em papel toalha como passo final.

A seguir, as placas foram bloqueadas com PBS/albumina bovina a $4 \%, 100 \mu \mathrm{L} /$ well e cobertas, incubando-se à temperatura ambiente por duas horas, lavando-se cinco vezes com Tris/ $\mathrm{HCl}$.

Adicionaram-se os padrões, $25 \mu \mathrm{L} /$ orifício concomitantemente com as amostras e o Anticorpo biotinilado anti-citocina a $1 \mu \mathrm{g} / \mathrm{mL}$ em PBS/albumina bovina $1 \%$ ). Cobriu-se e incubou-se por duas horas à temperatura ambiente. Lavou-se cinco vezes em Tris/HCl.

Diluiu-se a estreptavidina-peroxidase de acordo com as recomendações do fabricante (1:1000 de uma solução de $1 \mathrm{mg} / \mathrm{mL}$ ). Adicionaram-se $100 \mu \mathrm{L} /$ alvéolo. Cobriu-se e incubou-se à temperatura ambiente por 30 minutos. Lavou-se cinco vezes com Tris/ $\mathrm{HCl}$.

Descongelou-se o substrato TMB dentro de 5 minutos para a utilização. Adicionou-se $10 \mu \mathrm{L}$ de $\mathrm{H}_{2} \mathrm{O}_{2}$ para $10 \mathrm{~mL}$ de substrato e misturou-se em vórtex. Imediatamente adicionou-se $100 \mu \mathrm{L} /$ orifício e deixou-se revelar à 
temperatura ambiente por 10 a 30 minutos, na dependência do desenvolvimento da reação. A reação colorimétrica foi neutralizada pela adição de $100 \mu \mathrm{L}$ de $\mathrm{H}_{2} \mathrm{SO}_{4} 1 \mathrm{M}$. A leitura foi realizada a $450 \mathrm{~nm}$ em espectrofotômetro para leitura de placas de ELISA. As soluções e tampões estão descritos no ANEXO B.

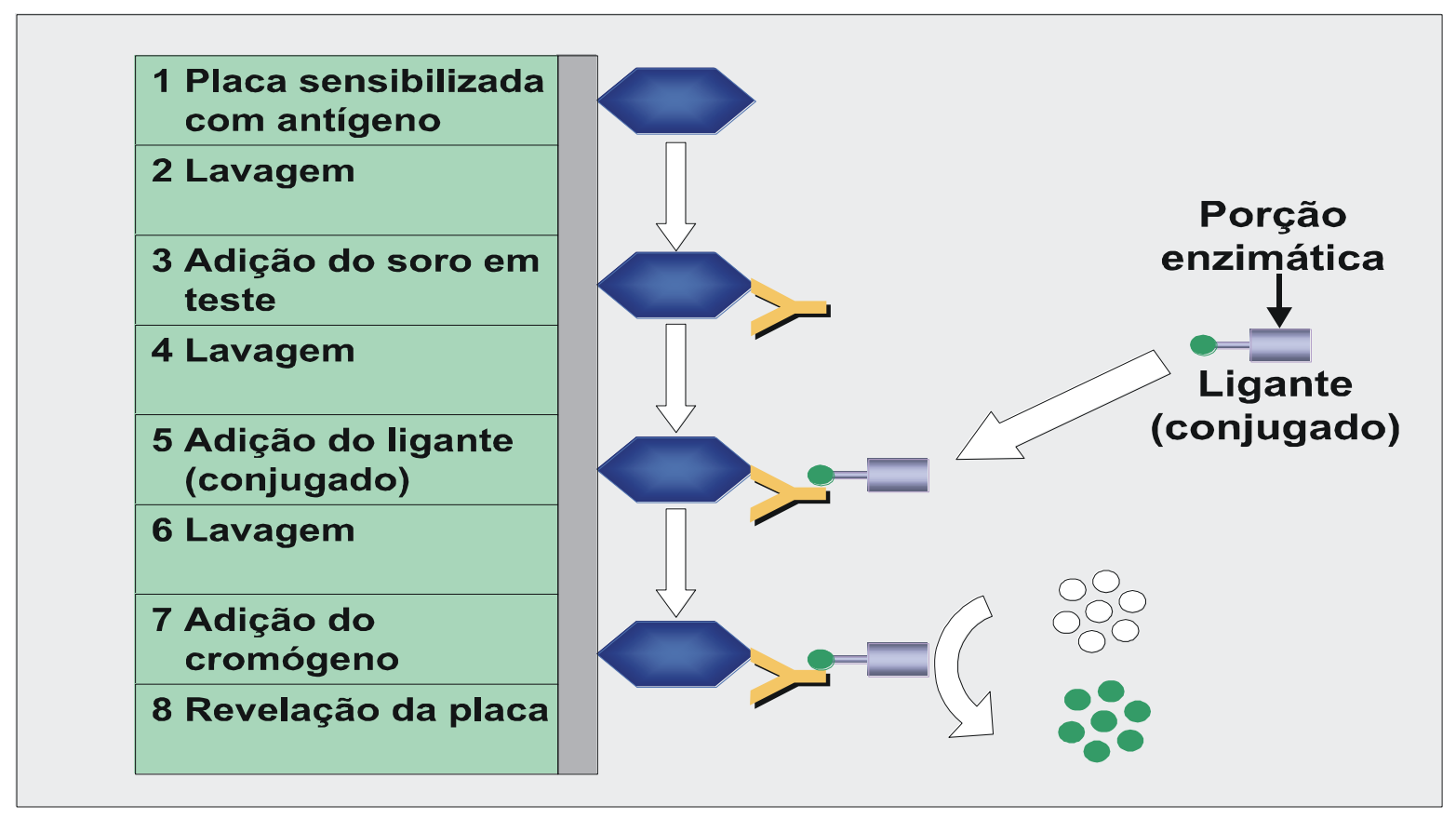

Figura 5 - Esquema explicativo da técnica de ELISA (Enzyme Linked Immunosorbent Assay) para as citocinas IL-4, IL-10, IL-12 e IFN-y. 


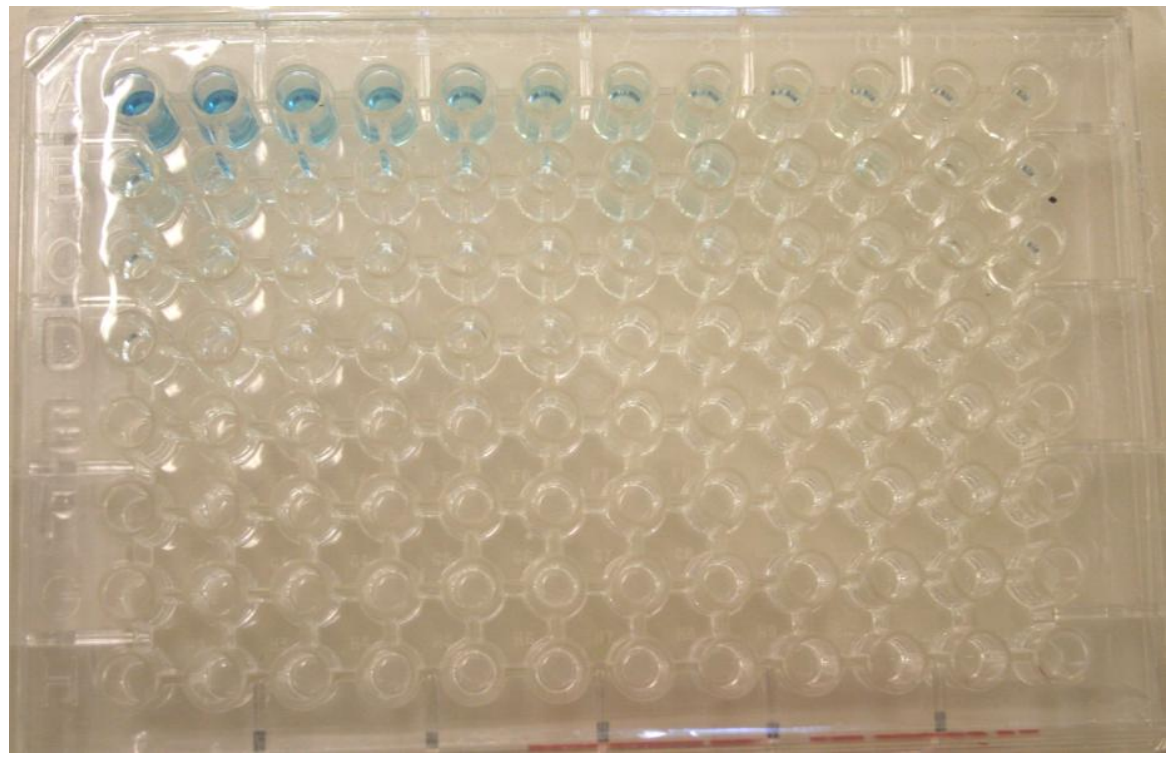

Figura 6 - Coloração por TMB na dosagem de citocinas pela técnica de ELISA.

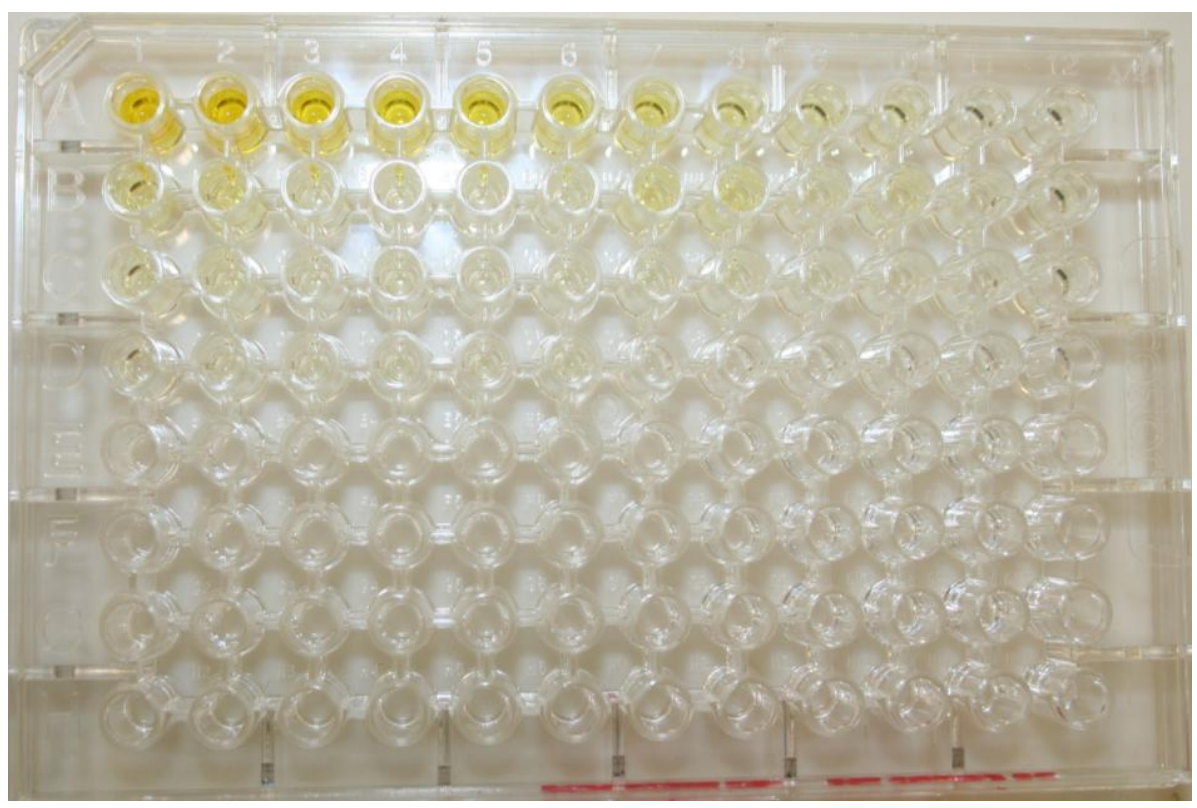

Figura 7 - Dosagem de citocinas; a reação é parada por Ácido Sulfúrico $\left(\mathrm{H}_{2} \mathrm{SO}_{4}\right)$.

\subsection{Estatística}

Para as diversas comparações intragrupo (tanto controles quanto pacientes), foi usado o teste de comparações para medidas repetidas de Friedmann, com pós teste de Student-Newman-Keuls. Quando comparados 
o mesmo parâmetro (dois a dois) entre pacientes e controles, foi utilizado o teste não paramétrico de Mann-Whitney. Foram considerados significantes os valores de $p<0,05$. 


\section{RESULTADOS}

\subsection{Dosagens de Proteínas e Açúcares totais}

Após a extração do fungo com o líquido de Coca, que havia sido cultivado no meio Czapeck modificado por 60 dias, foram realizadas dosagens de proteínas totais por dois métodos, o de Bradford $(717 \mu \mathrm{g} / \mathrm{mL})$ e de Lowry $(5.500 \mu \mathrm{g} / \mathrm{mL})$; e dosagem de açúcares totais pela técnica de DuBois $(2.000 \mu \mathrm{g} / \mathrm{mL})$.

\subsection{Curva de Proliferação em resposta ao extrato pelas} concentrações de proteínas totais obtidas pelos métodos de Lowry e Bradford

Para determinar qual método de dosagem de proteínas totais apresentava melhor fidelidade, foi realizado um ensaio de proliferação de linfócitos teste, utilizando células de dois indivíduos do grupo controle, as quais foram colocadas frente a estímulo do extrato em diferentes concentrações, $40 \mu \mathrm{g}, 20 \mu \mathrm{g}, 10 \mu \mathrm{g}, 5 \mu \mathrm{g}$ e $2,5 \mu \mathrm{g}$, a partir das dosagens obtidas por cada método (Lowry, $5.500 \mu \mathrm{g} / \mathrm{mL}$, e Bradford, $717 \mu \mathrm{g} / \mathrm{mL}$ ). Optou-se por padronizar o ensaio de proliferação de linfócitos com a concentração baseada na quantificação protéica pelo método de Bradford, que se mostrou mais fidedigna. 


\section{Grafico - Resposta Linfoproliferativa ao extrato pelas concentrações de proteínas obtidas pelas técnicas de Lowry e Bradford}

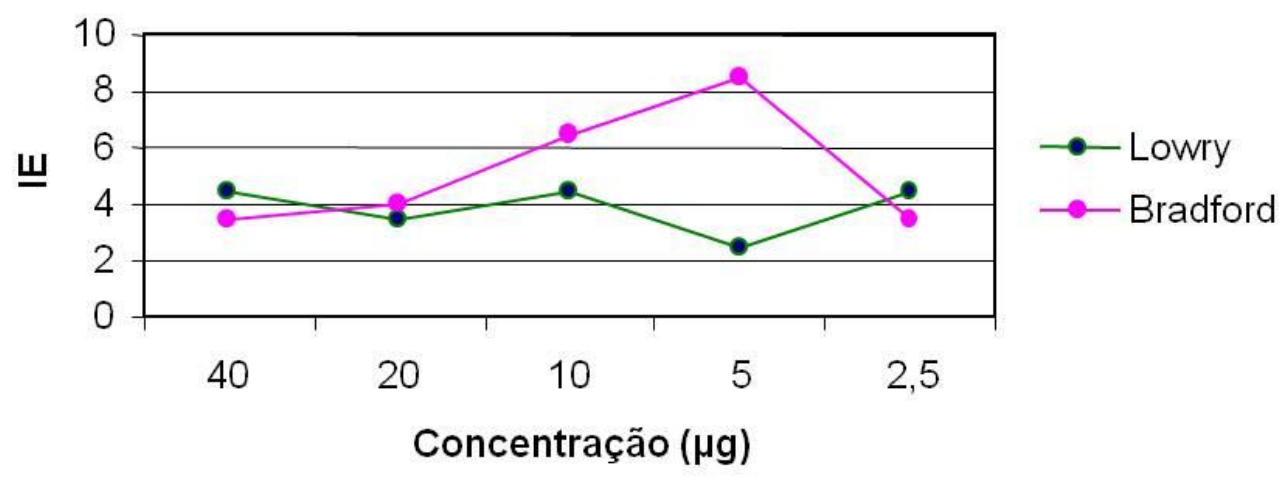

Figura 8 - Resposta linfoproliferativa ao extrato do Trichophyton rubrum, nas

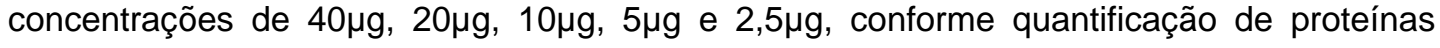
realizada pelas técnicas de Bradford e Lowry.

\subsection{Eletroforese em gel de poliacrilamida contendo dodecil sulfato de sódio (SDS-PAGE)}

A técnica de eletroforese em gel de poliacrilamida em meio redutor (SDS-PAGE), permitiu observarmos diversas proteínas do Trichophyton rubrum, com pesos moleculares aproximados de 60, 50 e $35 \mathrm{kDa}$ (quilodaltons), nas seguintes concentrações do extrato: 2,0 $\mu \mathrm{g}, 1,5 \mu \mathrm{g}$ e $1,25 \mu \mathrm{g}$, como mostra a figura 9. 


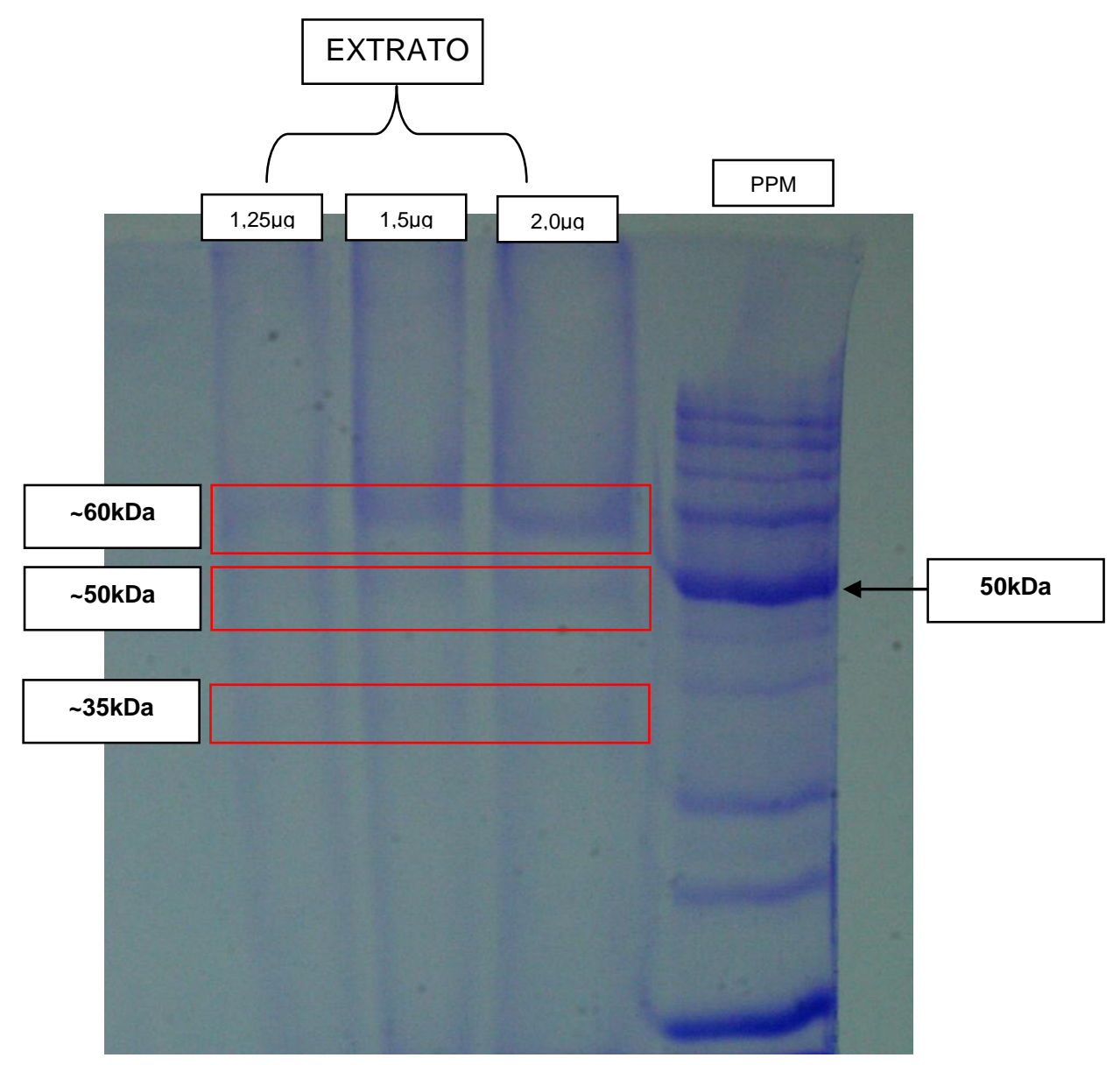

Figura 9 - Gel de poliacrilamida (SDS-PAGE) mostrando a presença das proteínas do fungo Trichophyton rubrum, apresentando os dados de peso molecular em $\mathrm{kDa}$ (quilodaltons). Observam-se proteínas com pesos moleculares de aproximadamente 60 kDa, 50 kDa e 35 $\mathrm{kDa}$ em concentrações diferentes. PPM = Padrão de peso molecular.

\subsection{Fenotipagem celular}

Os resultados da imunofenotipagem podem ser vistos nas Figuras 10 (controles) e 11 (pacientes), logo abaixo. É importante ressaltar que não houve alteração de nenhuma população celular no grupo de pacientes, assim como não houve diferença estatística em nenhuma das populações estudadas. Com relação ao receptor de manose CD206, podemos observar semelhança dos resultados entre os grupos estudados $(p=0,37)$, onde a mediana da imunofenotipagem do grupo controle foi de $9,4 \%$ da população 
de células (sendo que houve uma variação de 4,2\% a 15,1\%, conforme o percentil (P) 25 e o P75) e para o grupo de pacientes a mediana foi de 5,6\% da população de células (sendo que houve uma variação de 1,8\% a 12,7\%, conforme o P25 e o P75). Os dados relativos à imunofenotipagem encontram-se nas tabelas 9 e 10, no Anexo D.

\section{Controles fenotipagem}

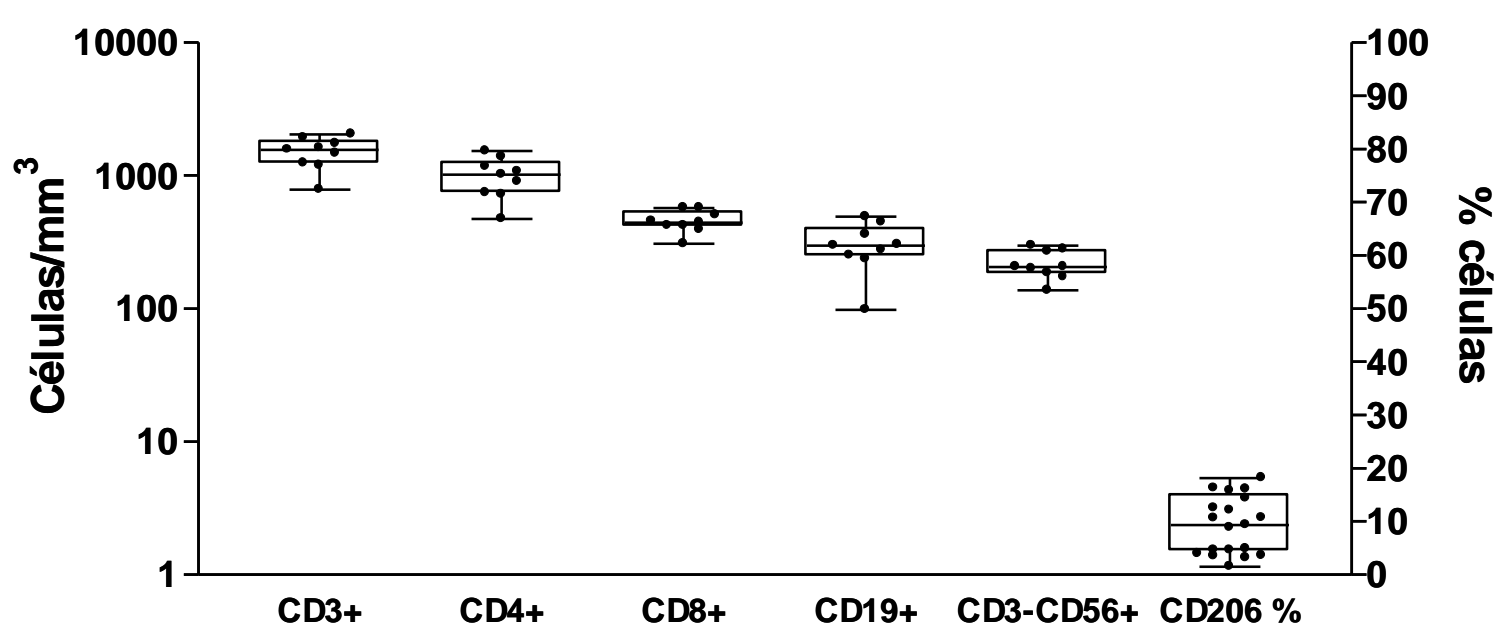

Figura 10 - Quantificação do número de células imunocompetentes dos indivíduos do grupo controle. Estão aqui apresentados os dados relativos a linfócitos $T$, B e células NK em número absoluto (eixo Y1, à esquerda) e da expressão percentual de CD206, o receptor de manose de monócitos (eixo Y2, à direita). 


\section{Pacientes fenotipagem}

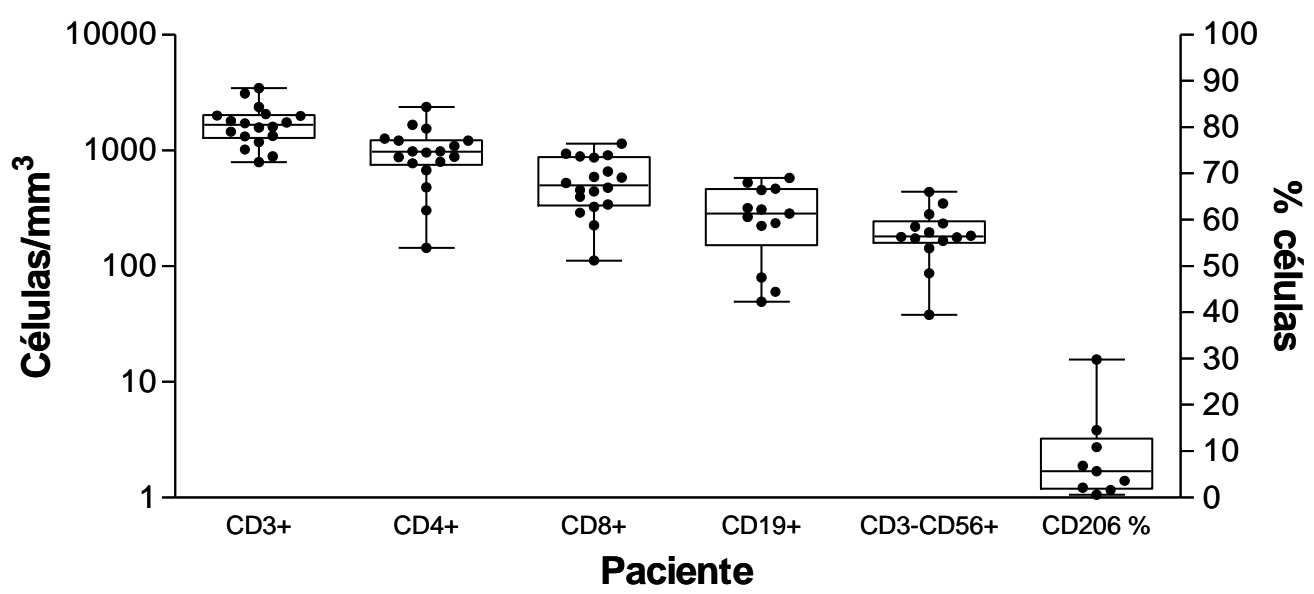

Figura 11 - Quantificação do número de células imunocompetentes dos indivíduos do grupo pacientes. Estão aqui apresentados os dados relativos a linfócitos $\mathrm{T}$, B e células NK em número absoluto (eixo Y1, à esquerda) e da expressão percentual de CD206, o receptor de manose de monócitos (eixo Y2, à direita).

\subsection{Culturas celulares}

Dos ensaios realizados com células mononucleares dos 14 indivíduos do grupo controle, foi possível observar que alguns desses indivíduos obtiveram índices de estimulação considerados positivos, em pelo menos uma concentração do extrato (Tabela 3, marcados em negrito). Entre os pacientes com dermatofitose extensa (Tabela 4), apenas dois indivíduos tiveram resposta positiva ao extrato de $T$. rubrum. Quando estes dados foram confrontados estatisticamente não obtiveram significância $(P>0.05)$, em decorrência do pequeno número de indivíduos estudados. Os dados da análise estatística dos grupos de controles e de pacientes estão no Anexo D. 
Tabela 3 - Índices de Estimulação das Culturas de Linfócitos de 6 dias, para 0 grupo Controle.

\begin{tabular}{|c|c|c|c|c|c|c|c|c|c|c|c|}
\hline Indivíduo & CMA & PWM & $\mathrm{TT}$ & P1:6,25 & P1:12,5 & P1:25 & P1:50 & $\begin{array}{c}E \\
40 \mu \mathrm{g} / \mathrm{mL}\end{array}$ & $\begin{array}{c}E \\
20 \mu \mathrm{g} / \mathrm{mL}\end{array}$ & $\begin{array}{c}E \\
10 \mu \mathrm{g} / \mathrm{mL}\end{array}$ & $\begin{array}{c}E \\
5 \mu \mathrm{g} / \mathrm{mL}\end{array}$ \\
\hline I & 54,0 & 146,0 & & 1,2 & 1,0 & 1,0 & 1,0 & 3,0 & 10,0 & 1,0 & 1,0 \\
\hline II & 3,0 & 93,0 & 13,0 & 0,8 & 1,0 & 1,0 & 1,0 & 3,0 & 3,0 & 2,0 & 2,0 \\
\hline III & 0,0 & 54,0 & 1,0 & 1,0 & 1,0 & 1,0 & 1,0 & 0,0 & 1,0 & 1,0 & 0,0 \\
\hline IV & 8,0 & 377,0 & 7,0 & 1,0 & 1,0 & 1,0 & 1,0 & 1,0 & 1,0 & 1,0 & 1,0 \\
\hline V & 6,0 & 51,0 & 15,0 & 1,0 & 1,0 & 1,0 & 1,0 & 1,0 & 1,0 & 1,0 & 1,0 \\
\hline VI & 4,0 & 67,0 & 9,0 & 0,0 & 0,0 & 0,0 & 0,0 & 0,0 & 0,0 & 0,0 & 0,0 \\
\hline VII & 3,0 & 116,0 & 4,0 & 1,0 & 0,0 & 1,0 & 0,0 & 1,0 & 1,0 & 0,0 & 1,0 \\
\hline VIII & 18,0 & 201,0 & 1,0 & 1,0 & 1,0 & 1,0 & 1,0 & 1,0 & 2,0 & 1,0 & 2,0 \\
\hline IX & 1,0 & 93,0 & 1,0 & 1,0 & 1,0 & 1,0 & 2,0 & 1,0 & 1,0 & 1,0 & 1,0 \\
\hline$x$ & 2,0 & 59,0 & 11,0 & 3,4 & 5,0 & 4,0 & 5,0 & 1,0 & 1,0 & 1,0 & 1,0 \\
\hline$X I$ & 1,0 & 52,0 & & 1,0 & 1,0 & 1,0 & 1,0 & 2,0 & 2,0 & 2,0 & 1,0 \\
\hline XII & 14,0 & 66,0 & 8,0 & 0,6 & 1,0 & 1,0 & 1,0 & 2,0 & 3,0 & 2,0 & 1,0 \\
\hline XIII & 0,0 & 42,0 & 2,0 & 0,5 & 0,0 & 0,0 & 0,0 & 1,0 & 1,0 & 0,0 & 0,0 \\
\hline XIV & 1,0 & 46,0 & 11,0 & 6,6 & 4,0 & 5,0 & 7,0 & 4,0 & 2,0 & 2,0 & 1,0 \\
\hline
\end{tabular}

Considera-se Índice de Estimulação ideal $\geq 3$ para antígenos, $\geq 2$ para peptídeos, e $\geq 10$ para o mitógeno do PWM (marcadas em negrito) CMA: Candida sp; PWM: mitógeno do pokeweed; P: Peptídeo YIIDTGIDID; E: Extrato de Trichophyton rubrum.

Nos ensaios do grupo de pacientes, os indivíduos I e VI, (Tabela 4) apresentaram resposta ao extrato em todas as diluições diferentes $(5 \mu \mathrm{g} / \mathrm{ml}$, $10 \mu \mathrm{g} / \mathrm{ml}, 20 \mu \mathrm{g} / \mathrm{ml}$ e $40 \mu \mathrm{g} / \mathrm{ml}$ ), demonstrando que alguns desses pacientes possuem capacidade celular de reconhecer, diferenciar e multiplicar, pelo menos in vitro, quando estão sobre o estímulo do fungo T. rubrum, embora isto não reflita uma capacidade efetora das células. 
Tabela 4 - Índices de Estimulação, das Culturas de Linfócitos de 6 dias, para o grupo de Pacientes com Dermatofitose Extensa

\begin{tabular}{cccccccccccc}
\hline & & & & & & & & $E$ & $E$ & $E$ & $E$ \\
Indivíduo & CMA & PWM & TT & P1:6,25 & P1:12,5 & P1:25 & P1:50 & $40 \mu \mathrm{g} / \mathrm{mL}$ & $20 \mu \mathrm{g} / \mathrm{mL}$ & $10 \mu \mathrm{g} / \mathrm{mL}$ & $5 \mu \mathrm{g} / \mathrm{mL}$ \\
\hline I & $\mathbf{1 3 , 0}$ & 8,0 & & & 1,0 & 1,0 & 1,0 & 6,0 & 5,0 & 5,0 & 3,0 \\
II & 1,0 & 31,0 & & & 1,0 & 1,0 & 1,0 & 2,0 & 2,0 & 2,0 & 0,0 \\
III & 0,0 & 33,0 & 1,0 & 0,6 & 1,0 & & 1,0 & 1,0 & 1,0 & 1,0 & 0,0 \\
IV & 1,0 & 62,0 & 1,0 & 0,6 & 1,0 & 1,0 & 1,0 & 2,0 & 1,0 & 1,0 & 1,0 \\
V & & 34,0 & & 0,6 & 1,0 & 1,0 & 1,0 & 1,0 & 1,0 & 1,0 & 1,0 \\
VI & $\mathbf{2 7 , 0}$ & $\mathbf{3 1 , 0}$ & 2,0 & 0,6 & 1,0 & 1,0 & 1,0 & $\mathbf{4 1 , 0}$ & $\mathbf{3 2 , 0}$ & $\mathbf{2 8 , 0}$ & $\mathbf{2 3 , 0}$ \\
VII & 1,0 & 26,0 & 1,0 & & & & & 1,0 & 1,0 & 1,0 & 1,0 \\
VIII & 1,0 & 213,0 & & 1,0 & 1,0 & 1,0 & 1,0 & 1,0 & 1,0 & 1,0 & 1,0 \\
\hline
\end{tabular}

Considera-se Índice de Estimulação ideal $\geq 3$ para antígenos, $\geq 2$ para peptídeos, e $\geq 10$ para o mitógeno do Pokeweed (marcadas em negrito) CMA: Candida sp; PWM: mitógeno do pokeweed; P: Peptídeo YIIDTGIDID; E: Extrato de Trichophyton rubrum.

Os dados relativos às culturas celulares podem ser vistos nas figuras 12 a 16, abaixo apresentadas. Pudemos evidenciar diferenças estatisticamente significativas entre o grupo de controles e o grupo de pacientes para as culturas estimuladas por estímulos inespecíficos como o mitógeno da Phytolacca americana - Pokeweed - PWM $(p=0,0005)$ e para um antígeno não relacionado, no caso o antígeno metabólico de Candida $(C M A)-(p=0,0092)$ (Vide Figura 12). 


\section{Controles X Pacientes}

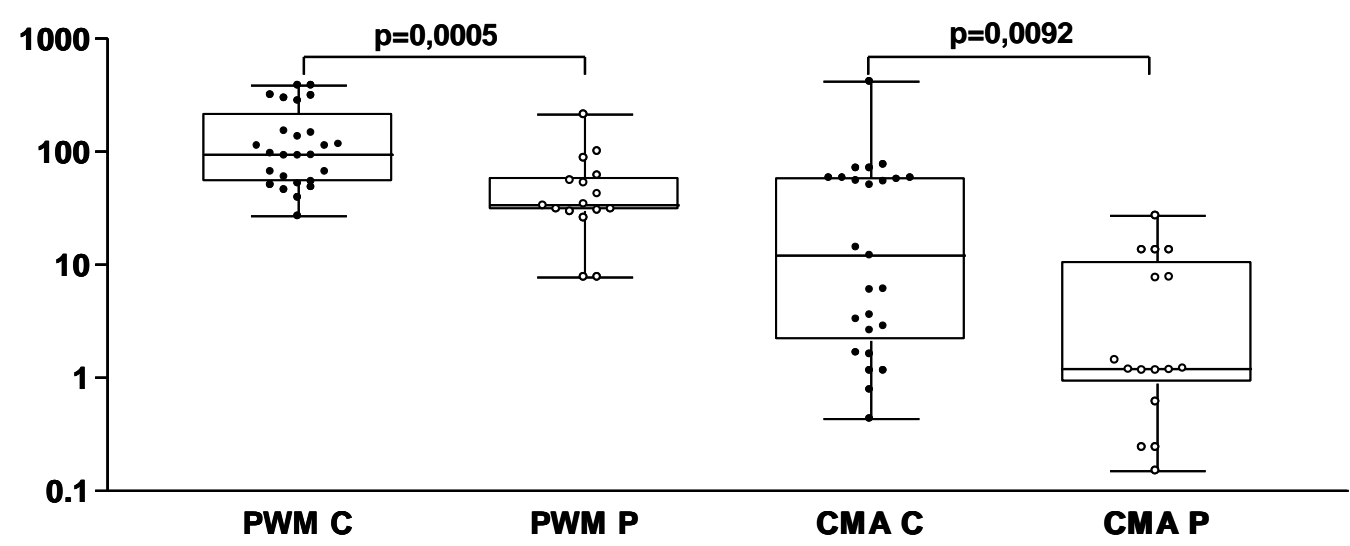

Figura 12 - Comparação entre o grupo de controles $(C)$ e de pacientes (P) sob estímulo inespecífico pelo PWM e por antígeno não relacionado (CMA). Observa-se que a resposta a esses estímulos foi estatisticamente diferente entre os dois grupos $(\mathrm{p}=0,0005$ para $\mathrm{PWM}$ e $\mathrm{p}=0,0092$ para $\circ \mathrm{Ag}$ metabólico de Candida). Resultados apresentados em índice de estimulação (eixo $\mathrm{Y}$ ). Considera-se uma resposta normal um Índice de Estimulação $\geq 3$ para CMA, e $\geq 10$ para PWM. (CMA: Ag metabólico de Candida sp; PWM: mitógeno do pokeweed).

Quanto aos antígenos específicos do fungo T. rubrum, podemos observar que existe uma resposta considerada positiva para diversos indivíduos do grupo controle (Figura 13) como também do grupo de pacientes (Figura 14). 


\section{Controles - Extrato antigênico}

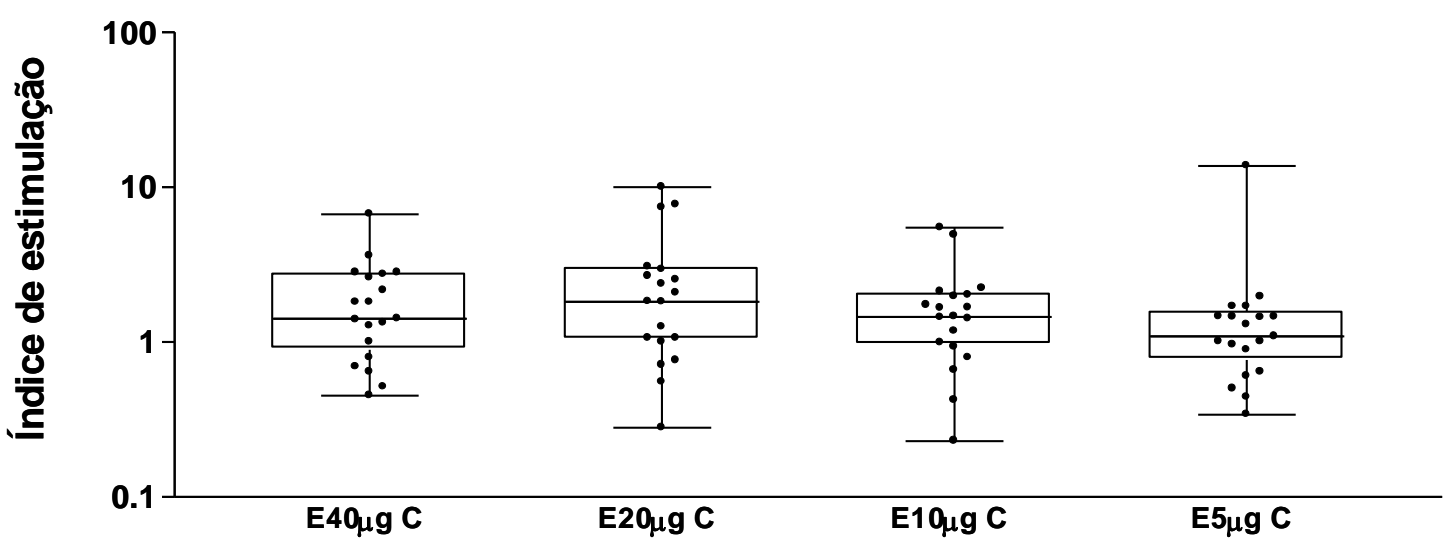

Figura 13 - Resposta linfoproliferativa dos indivíduos do grupo controle a diferentes concentrações do extrato antigênico derivado do fungo Trichophyton rubrum. Resultados apresentados em índice de estimulação (eixo Y). Resposta positiva $>3$.

\section{Pacientes - Extrato antigênico}

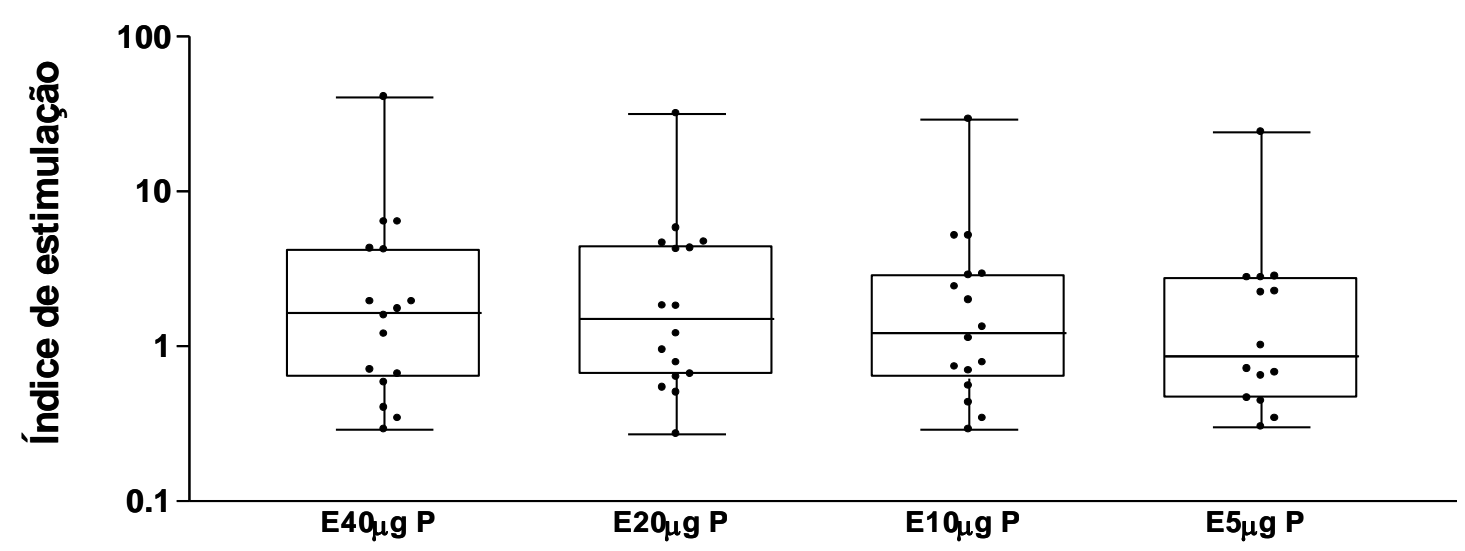

Figura 14 - Resposta linfoproliferativa dos pacientes a diferentes concentrações do extrato antigênico derivado do fungo Trichophyton rubrum. Resultados apresentados em índice de estimulação (eixo Y). Resposta positiva $>3$. 
Tendo-se em conta as culturas estimuladas pelo peptídeo antigênico utilizado (YIIDTGIDID) podemos observar um comportamento diferente das células estimuladas pelo extrato antigênico preparado a partir da extração de culturas puras do fungo (Figuras 15 e 16).

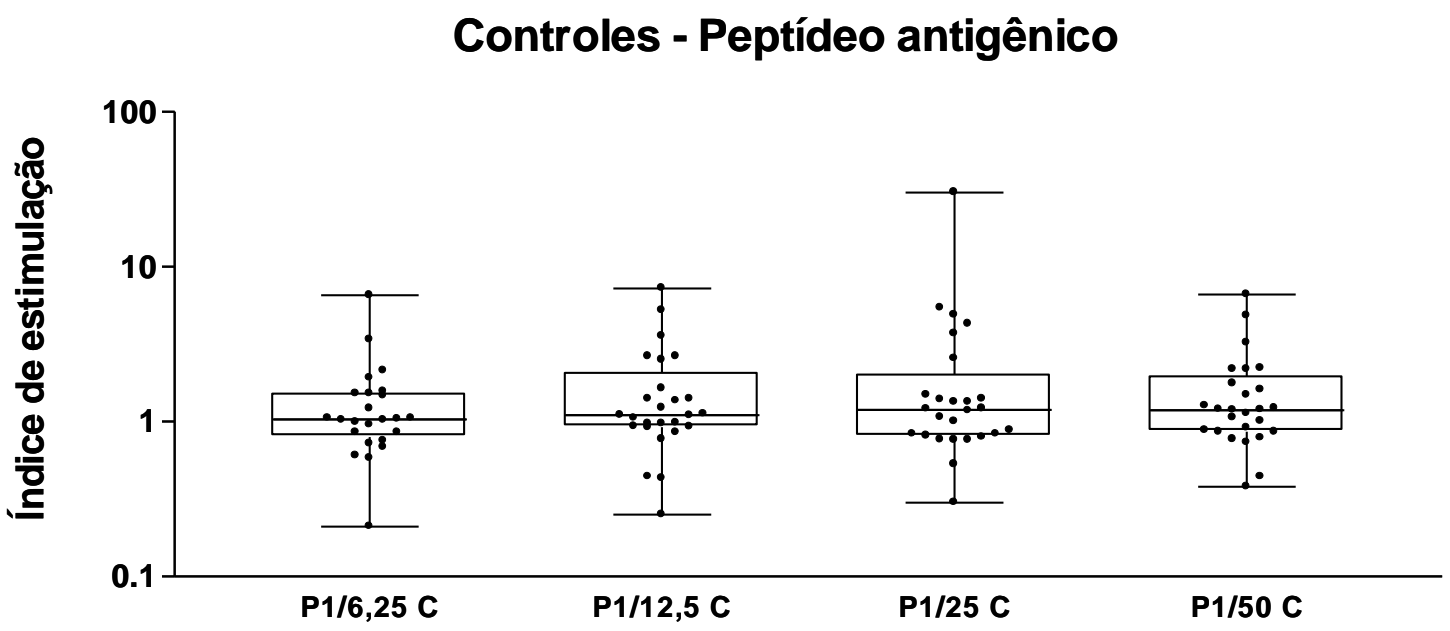

Figura 15 - Resposta linfoproliferativa dos indivíduos do grupo controle a diferentes concentrações do peptídeo antigênico imunodominante (YIIDTGIDID) derivado do fungo Trichophyton rubrum. Resultados apresentados em índice de estimulação (eixo Y). Resposta positiva $>2$.

\section{Pacientes - Peptídeo antigênico}

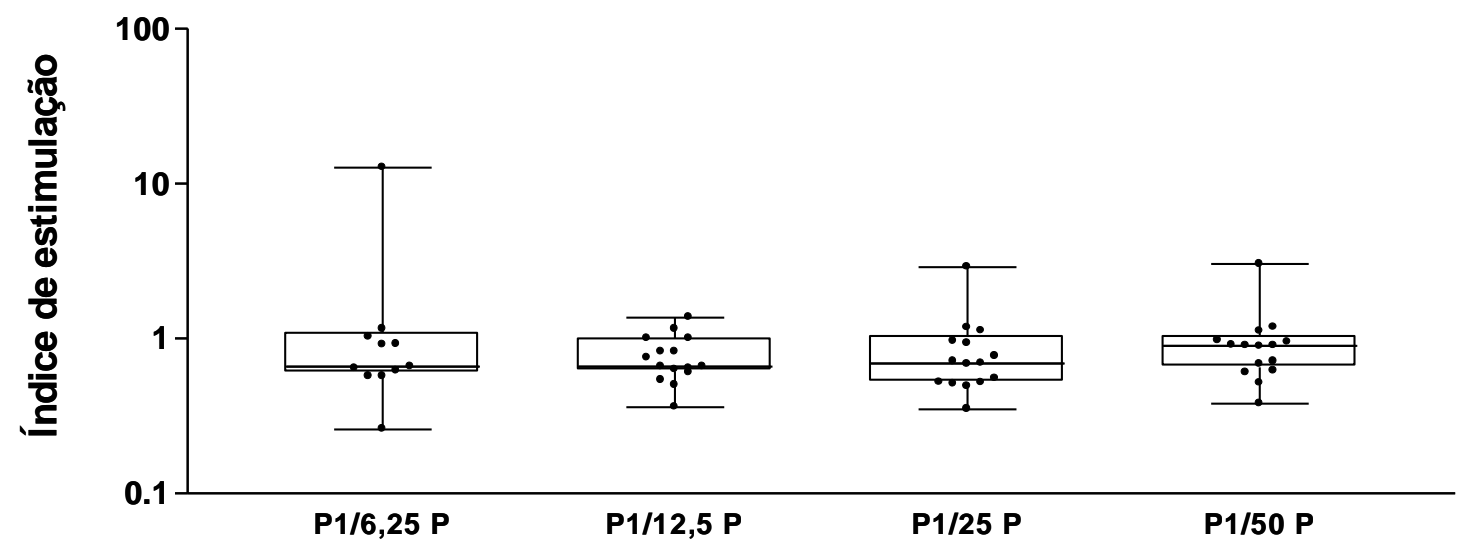

Figura 16 - Resposta linfoproliferativa dos pacientes a diferentes concentrações do peptídeo antigênico imunodominante (YIIDTGIDID) derivado do fungo Trichophyton rubrum. Resultados apresentados em índice de estimulação (eixo Y). Resposta positiva > 2. 
A Figura 17 demonstra os índices de Estimulação comparados entre os grupos controle e pacientes sob estímulo pelo extrato antigênico preparado a partir do cultivo do fungo. Podemos observar a semelhança dos resultados entre os controles $(\mathrm{C})$ e os pacientes $(\mathrm{P})$, inclusive com um paciente apresentando resposta bastante elevada, maior que todos os indivíduos do grupo controle.

\section{Controles X Pacientes - Extrato antigênico}

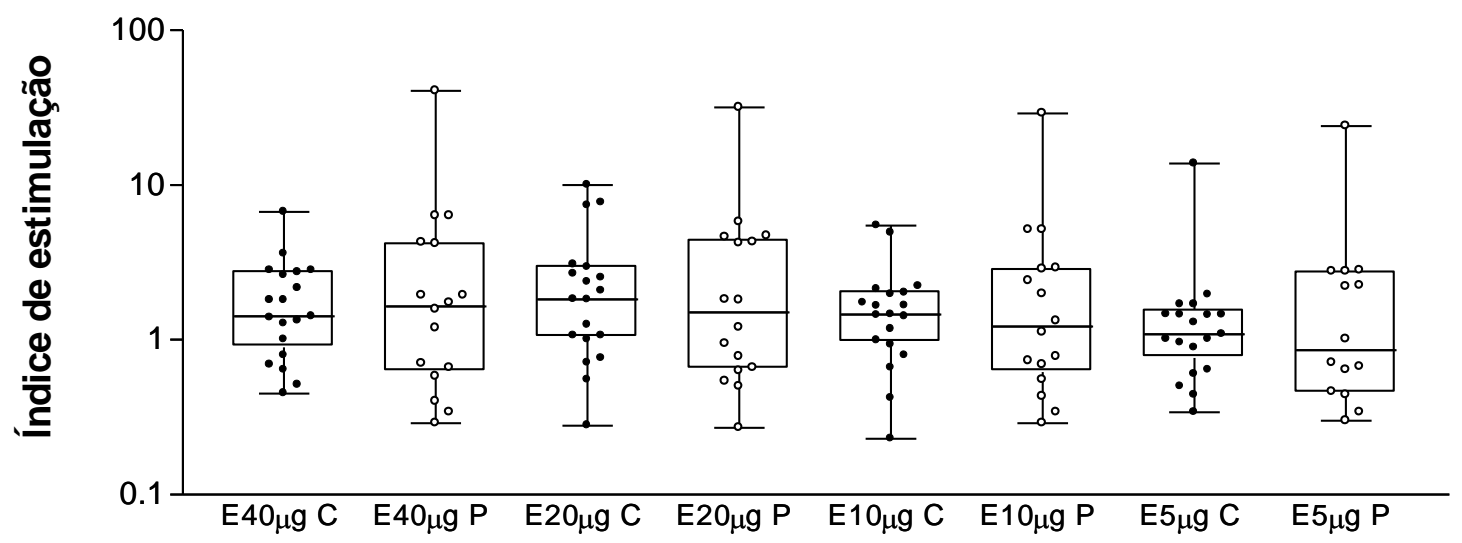

Figura 17 - Comparação da resposta linfoproliferativa dos indivíduos do grupo controle e dos pacientes a diferentes concentrações do extrato antigênico derivado do fungo Trichophyton rubrum. Resultados apresentados em índice de estimulação (eixo Y). Resposta positiva $>3$.

A Figura 18 demonstra os índices de Estimulação comparados entre os grupos controle e pacientes sob estímulo pelo peptídeo antigênico imunodominante sintetizado (YIIDTGIDID). Podemos observar a nítida tendência das células de indivíduos do grupo controle (C) apresentar índices de estimulação nitidamente superiores às células dos pacientes $(P)$. Essa diferença entre os grupos apresentou diferença estatisticamente significativa 
entre os grupos nas concentrações de 1:12,5, 1:25 e 1:50 ( $p=0,0036,0,0027$ e 0,0173 , respectivamente).

\section{Controles X Pacientes - Peptídeo}

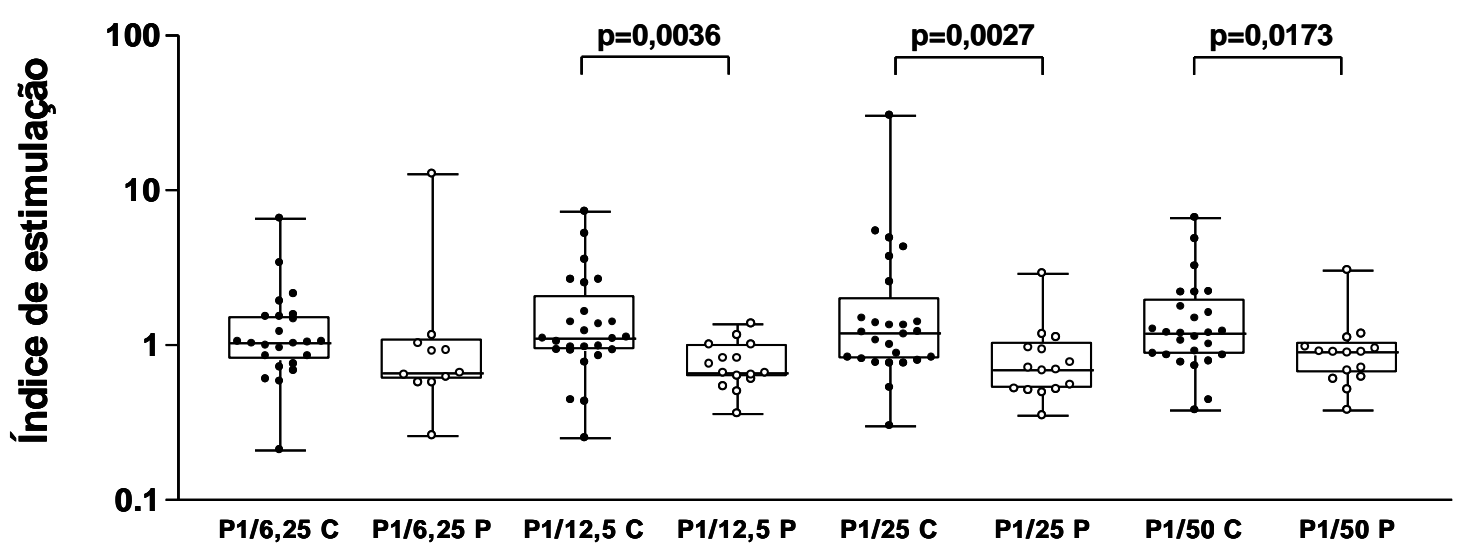

Figura 18 - Comparação da resposta linfoproliferativa dos indivíduos do grupo controle e dos pacientes a diferentes concentrações do peptídeo antigênico imunodominante (YIIDTGIDID) derivado do fungo Trichophyton rubrum. Resultados apresentados em índice de estimulação (eixo Y). Resposta positiva > 2.

\subsection{Quantificação de Citocinas}

Realizamos a quantificação de citocinas antiinflamatórias (IL-4 e IL10) e de duas citocinas relacionadas com o padrão $T_{h} 1$ (IL-12 e IFN-gama). Esses dados são apresentados a seguir nas figuras de 19 a 22. 


\section{IL-4}

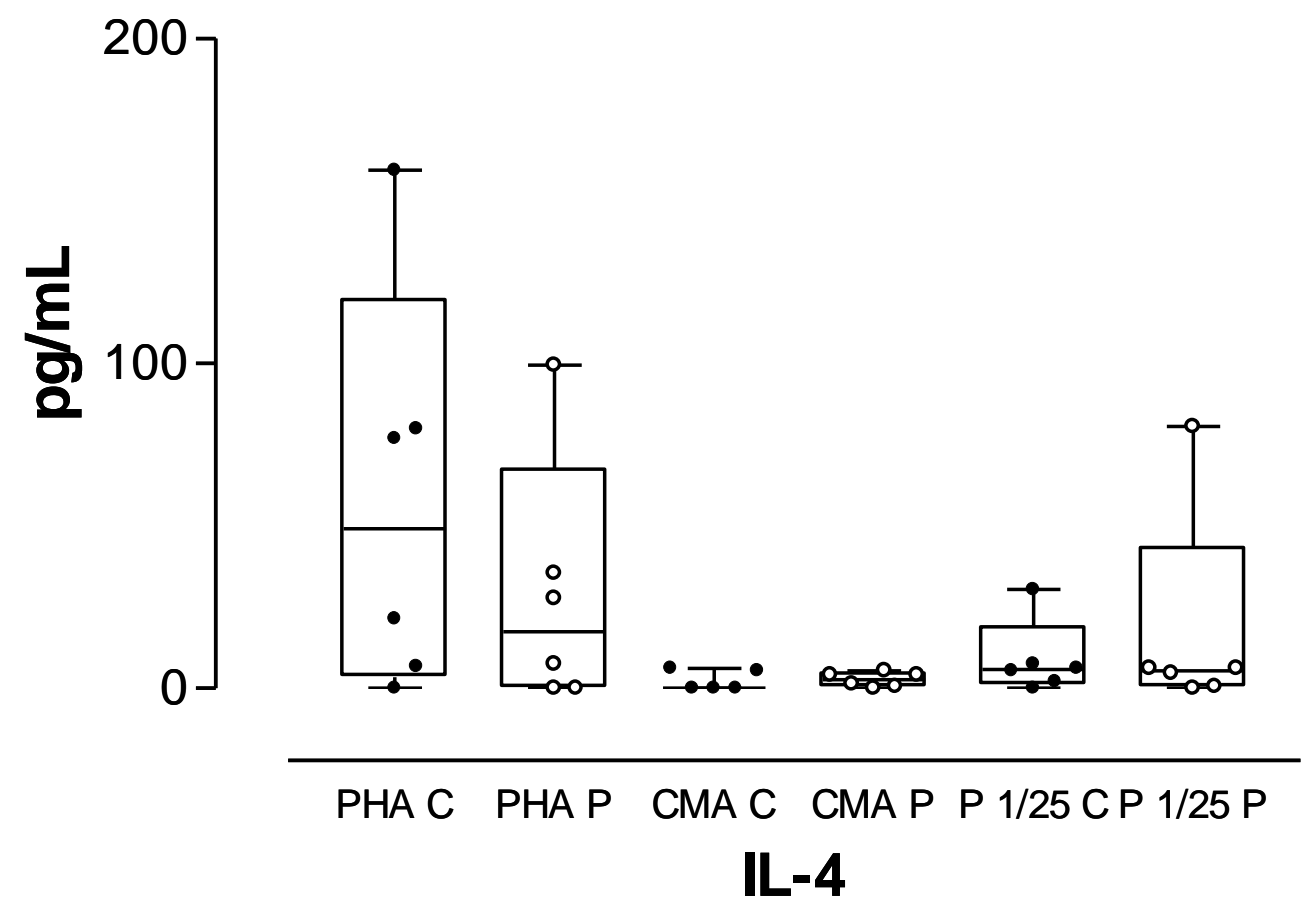

Figura 19 - Comparação da secreção de IL-4 por células mononucleares estimuladas por mitógeno (PHA) durante 24 horas, e por antígenos: CMA e o peptídeo YIIDTGIDID na diluição de 1:25 durante 72 horas, dos indivíduos do grupo controle e dos pacientes. Resultados apresentados em $\mathrm{pg} / \mathrm{mL}$ de IL-4 (eixo Y). Não foram observadas diferenças estatisticamente significativas entre o grupo de controles e de pacientes para os diferentes estímulos. 


\section{IL-10}

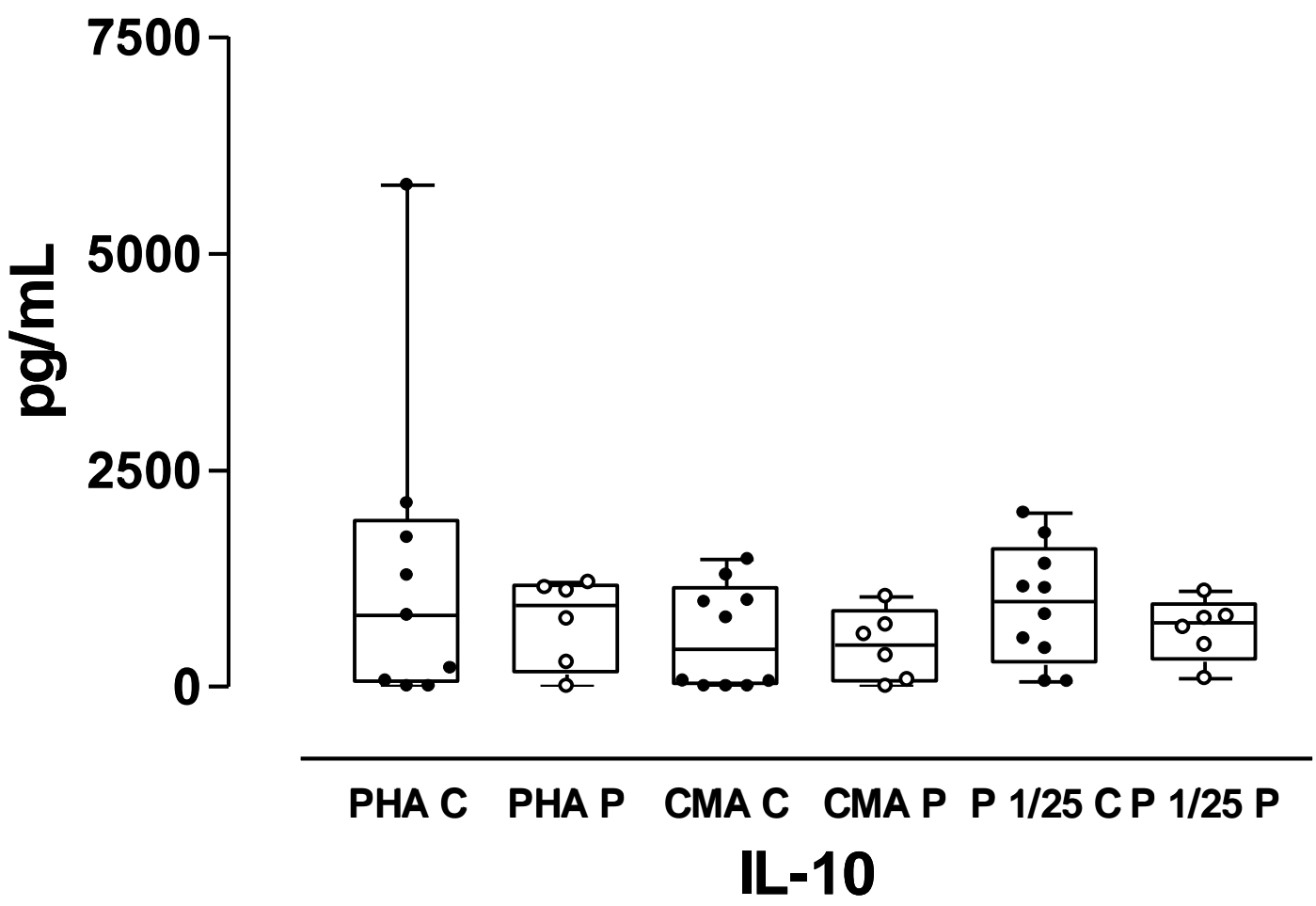

Figura 20 - Comparação da secreção de IL-10 por células mononucleares estimuladas por mitógeno (PHA) durante 24 horas, e por antígenos: CMA e o peptídeo YIIDTGIDID na diluição de 1:25 durante 72 horas, dos indivíduos do grupo controle e dos pacientes. Resultados apresentados em pg/mL de IL-10 (eixo Y). Não foram observadas diferenças estatisticamente significativas entre o grupo de controles e de pacientes para os diferentes estímulos. 


\section{IL-12}

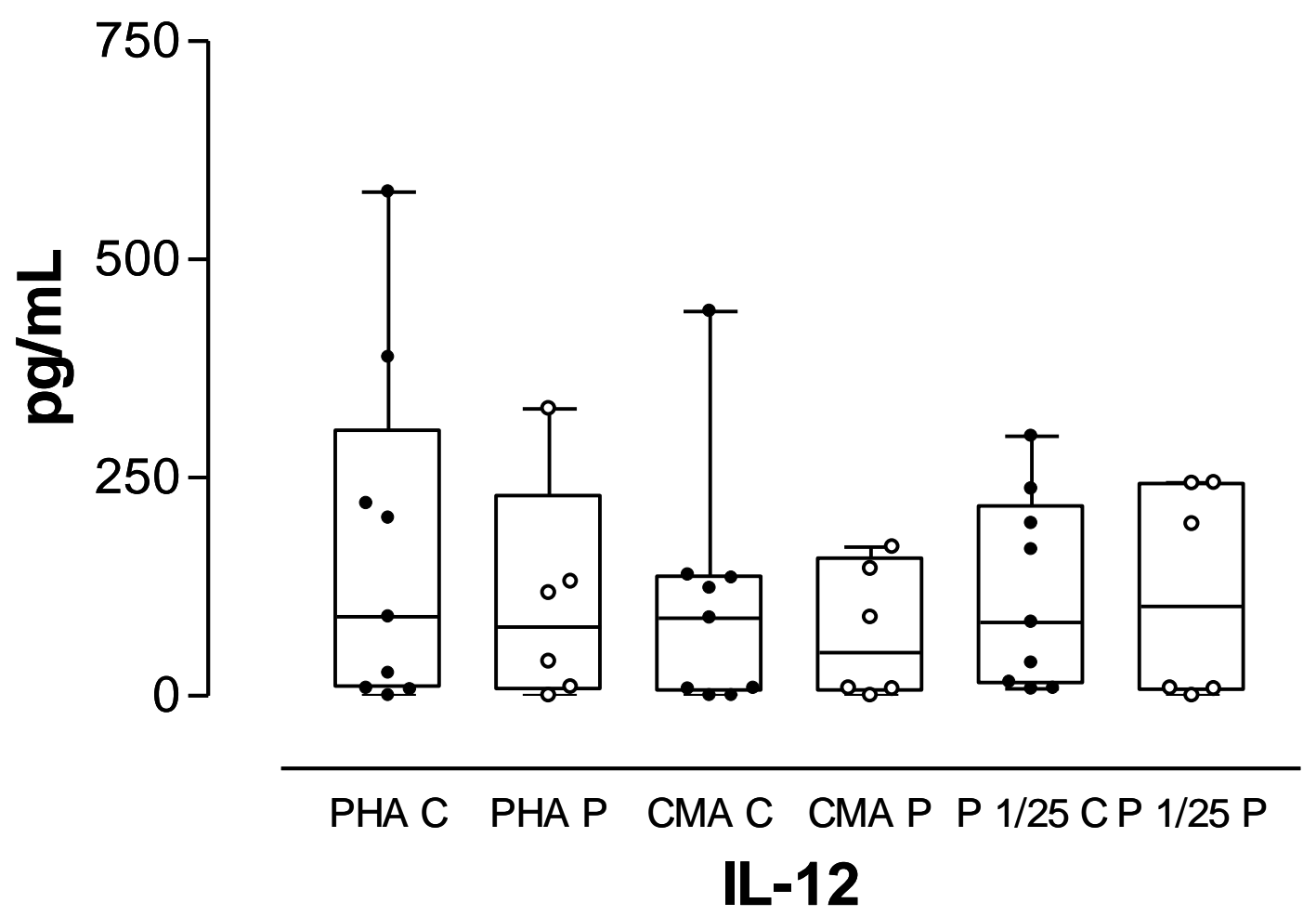

Figura 21 - Comparação da secreção de IL-12 por células mononucleares estimuladas por mitógeno (PHA) durante 24 horas, e por antígenos: CMA e o peptídeo YIIDTGIDID na diluição de 1:25 durante 72 horas, dos indivíduos do grupo controle e dos pacientes. Resultados apresentados em pg/mL de IL-12 (eixo Y). Não foram observadas diferenças estatisticamente significativas entre o grupo de controles e de pacientes para os diferentes estímulos. 


\section{IFN}

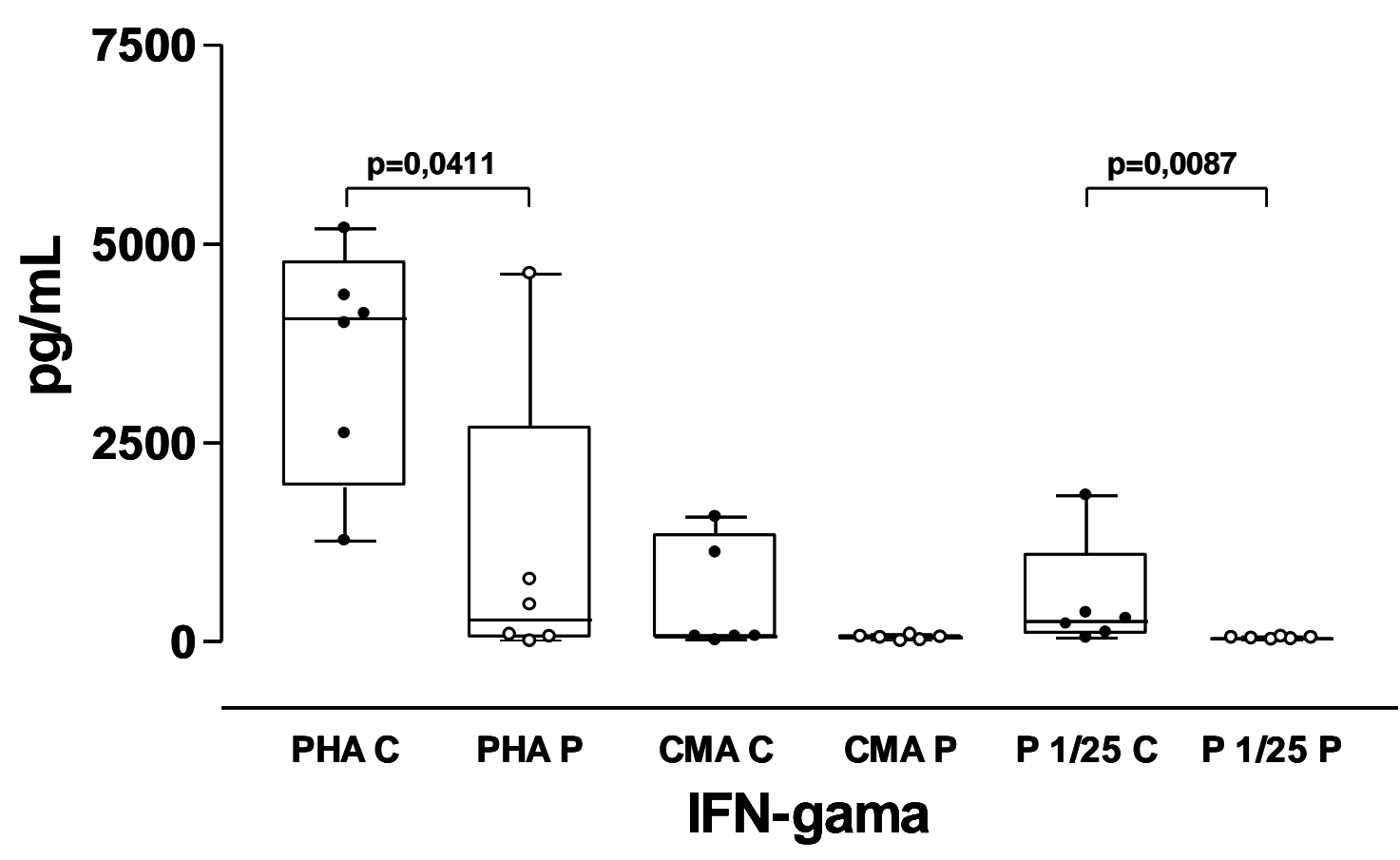

Figura 22 - Comparação da secreção de IFN-gama por células mononucleares estimuladas por mitógeno (PHA) durante 24 horas, e por antígenos: CMA e o peptídeo YIIDTGIDID na diluição de 1:25 durante 72 horas, dos indivíduos do grupo controle e dos pacientes. Resultados apresentados em $\mathrm{pg} / \mathrm{mL}$ de IFN-gama (eixo Y). Foram observadas diferenças estatisticamente significativas entre o grupo de controles e de pacientes para os estímulos PHA $(p=0,0411)$ e para o peptídeo $(p=0,0087)$. 


\section{DISCUSSÃO}

Os resultados deste estudo demonstraram que os portadores de dermatofitoses extensas por $T$. rubrum apresentam: números normais de linfócitos T e de suas subpopulações, de células B e NK, assim como expressão normal de CD206 (receptor de manose de monócitos). Os dados relativos à imunofenotipagem linfocitária sugerem um distúrbio sutil da imunidade, sem repercussão quantitativa nessas células. A ausência de alterações na expressão de CD206 é importante por existirem distúrbios na expressão desse receptor em pacientes portadores de candidíase mucocutânea crônica, como visto em estudos feitos em nosso laboratório. $\mathrm{O}$ receptor de manose na superfície das células apresentadoras de antígeno atua como facilitador da fagocitose, resultando em estímulo de moléculas coestimulatórias, elevação da expressão de moléculas de MHC de classe II e ativação de resposta celular $T_{h} 1$, levando a degradação do fungo e produção de citocinas pró-inflamatórias. Portanto, a imunofenotipagem de CD206 não mostrou diferença estatisticamente significativa.

No tocante à resposta linfoproliferativa, foi possível caracterizar que os pacientes apresentaram redução da resposta imune celular ao mitógeno do PWM, apresentando diferença estatisticamente significativa em relação ao grupo controle. $\mathrm{O}$ mesmo foi observado na resposta ao antígeno metabólico de Candida ssp., sendo que alguns pacientes apresentaram 
resposta dentro dos limites da normalidade, contudo a maior parte deles apresentava ausência de resposta a esse fungo.

A técnica de extração com líquido de Coca demonstrou uma grande concentração protéica, quantificada em $717 \mu \mathrm{g} / \mathrm{mL}$ pelo método de Bradford e em $5.500 \mu \mathrm{g} / \mathrm{mL}$ pelo método de Lowry. Essa discrepância entre os valores de concentração encontrados nas duas técnicas pode decorrer, segundo Zaia et al (1998), pelo fato de que a técnica de Lowry apresenta resultado falso-positivo para proteínas, quando esta amostra possui açúcares, pois estes reagem com o reativo de Folin-Ciocalteau. Portanto esta técnica não é indicada como referencial de concentração real de proteínas de extratos glicoprotéicos. Além disso, no ensaio de proliferação de linfócitos teste, os índices de proliferação para as concentrações encontradas pela técnica de Bradford se mostraram superiores aos obtidos pela técnica de Lowry sobre as mesmas condições, corroborando os níveis falsamente elevados de proteínas quantificados pela técnica de Lowry. Devido a esses fatos, optamos por utilizar a concentração fornecida pelo método de Bradford na padronização do ensaio de proliferação de linfócitos para os grupos controle e paciente.

A concentração de Açúcares Totais no extrato $(2 \mathrm{mg} / \mathrm{mL})$ pode refletir a presença de mananas, cuja capacidade de imunossuprimir a resposta celular in vitro já foi demonstrado nos estudos de Blake et al. (1991) e Grando et al (1992). Talvez este seja o maior interferente a se levar em conta quanto aos baixos índices de proliferação nos indivíduos do grupo controle estimulados pelo extrato de $T$. rubrum. Estes achados levam a 
acreditar que são necessários métodos mais eficientes para diminuir as concentrações de açúcares do extrato de Trichophyton rubrum, a fim de aumentar os índices de resposta. O teste de SDS-PAGE foi realizado em diversas concentrações para confirmar a presença de proteínas no extrato do fungo, como pode ser observado na figura 9. Pudemos observar a presença de proteínas do extrato do Trichophyton rubrum, todavia para que sejam detectadas no soro dos pacientes as proteínas acessíveis ao anticorpo é necessário que se faça o ensaio de Western blotting.

Quanto aos ensaios de cultura utilizando peptídeo de Trichophytum rubrum (YIIDTGIDID) como estímulo, também foram obtidos baixos índices de estimulação, o que já era esperado, uma vez que um peptídeo gera uma resposta muito específica e com baixos índices de proliferação; este fato também foi descrito por Woodfolk et al (2001) em seus experimentos. Dos indivíduos do grupo controle somente três responderam ao estímulo do peptídeo YIIDTGIDID. Apenas um indivíduo (indivíduo XIV Tabela 3) apresentou resposta tanto para o peptídeo quanto para o extrato de $T$. rubrum.

Não houve diferença significante entre o grupo controle e o grupo de pacientes portadores de dermatofitose extensa. Também não houve diferença significativa nas culturas e índices de estimulação entre o Extrato de T. rubrum e o Peptídeo YIIDTGIDID. Esses achados podem ter decorrido do pequeno número de pacientes estudados, tornando-se difícil afirmar a significância por análises estatísticas, sendo necessário um número maior de indivíduos sadios testados aleatoriamente na população em geral, uma 
vez que, sendo o Trichophyton rubrum um fungo antropofílico que possui a capacidade de provocar infecção independente do estado imunológico do paciente, o número de indivíduos com índices de estimulação satisfatórios deve aumentar.

Para tanto, é necessário avaliar outras importantes questões antes de novos testes. Diminuindo a quantidade de açúcares totais presentes no extrato e aumentando a concentração de proteínas, teoricamente poderíamos aumentar a resposta celular. Quanto ao peptídeo, os dados encontrados condizem com o que já é de conhecimento da literatura, constituindo uma resposta pouco expressiva, porém bastante específica.

Esses resultados são encorajadores, visto que o extrato antigênico produzido é capaz de induzir resposta linfoproliferativa antígeno-específica em indivíduos sensibilizados. A síntese de um peptídeo específico do Trichophyton rubrum foi capaz de evidenciar resposta linfoproliferativa de indivíduos controle e até mesmo de um paciente. Além disso, os presentes extrato e peptídeo antigênico utilizados neste projeto podem ser utilizados para a quantificação da síntese de citocinas produzidas por linfócitos e por células apresentadoras de antígenos, secretadas em sobrenadantes de cultivo celular.

Cumpre ainda notar que receptores envolvidos no reconhecimento "inespecífico" de fungos, como o receptor de manose, outros receptores da família das lectinas do tipo $\mathrm{C}$ e receptores da família Toll, assim como moléculas responsáveis pela comunicação entre as diferentes populações celulares podem estar envolvidas nos distúrbios apresentados pelos 
pacientes e conseqüentemente relacionar-se à suscetibilidade a infecções por esses fungos.

Dessa forma, projetos subseqüentes devem ser desenvolvidos nesta área, de modo a poder caracterizar o real potencial de discriminação da resposta imunológica celular e do desenvolvimento de conhecimento sobre a imunidade celular nas infecções fúngicas superficiais pelo Trichophyton rubrum, agente de grande importância na patogenia humana. 


\section{CONCLUSÕES}

\section{Conclusão geral:}

Nosso projeto permitiu avaliar a resposta imunológica celular de pacientes portadores de dermatofitoses extensas.

\section{Conclusões específicas:}

Obtivemos extratos protéicos a partir da cultura do fungo. Os métodos de extração foram eficientes, conseguindo grande concentração de proteínas a partir da cultura do fungo. Pela técnica de SDS-PAGE, observamos a presença de proteínas do extrato do fungo T. rubrum, onde os valores são mostrados em pesos moleculares $(\mathrm{kDa})$, de aproximadamente 60, 50 e $35 \mathrm{kDa}$ em concentrações diferentes.

Os testes de linfoproliferação nos permitiram demonstrar índices de estimulação satisfatórios, diante de um fungo antropofílico de larga distribuição na população como o Trichophyton rubrum. Por outro lado, a grande concentração de açúcares pode ter interferido na resposta celular, uma vez que já é conhecido o efeito supressor das mananas na resposta celular in vitro.

A resposta linfoproliferativa ao peptídeo YIIDTGIDID apresentou índices de estimulação satisfatórios e mais específicos, porém isso não resultou em uma diminuição nas respostas proliferativas em ensaio in vitro. 
As quantificações de citocinas estimuladas por lectina mitogênica (PHA), antígeno não relacionado (CMA) e pelo peptídeo antigênico YIIDTGIDID, caracterizaram a normalidade das citocinas de padrão Th2 (IL4 e IL-10) e da citocina indutora de resposta Th1 produzida pelas células apresentadoras de antígeno (IL-12). Pudemos ainda observar que o IFNgama foi a única citocina capaz de discriminar os dois grupos (de controles e pacientes). 


\section{Anexo A}

A.1. Soluções utilizadas na técnica de separação de células mononucleares.

\section{A.1.1. Ficoll-Hypaque}

Ficoll $64,8 \mathrm{~g}$

Água destilada $750 \mathrm{~mL}$

Coloca-se em um Becker o Ficoll para ser diluído em água, sob agitação e protegido da luz, por aproximadamente 8 horas, em temperatura ambiente. Hypaque Urografina

Hypaque $134,2 \mathrm{~mL}$ Água destilada $145,8 \mathrm{~mL}$

Mistura-se a água e o Hypaque em uma proveta. Após isso, adiciona-se a solução de Ficoll e a solução Hypaque com água aos poucos e mede-se a densidade até chegar a 1.077. Acerta-se a densidade e submete-se a autoclavagem, armazenando-se em vidro âmbar à temperatura ambiente.

\section{A.1.2. RPMI - 1640}

Bicarbonato de sódio $2 \mathrm{~g}$

Hepes $2,383 g$

Gentamicina $40 \mathrm{mg} / \mathrm{L}$

RPMI 1640 $10,4 \mathrm{~g}$

Glicose 2g (caso o RPMI não seja suplementado) 
Coloca-se em um balão volumétrico todos os itens e mistura-se em água sob agitação contínua por aproximadamente 1 hora. Após a diluição, o filtra-se a solução em capela de segurança biológica. Após filtragem coloca-se em estufa controlada a $37^{\circ} \mathrm{C}$ por setenta e duas horas para verificação de alguma possível contaminação. 
Anexo B

B.1. Soluções utilizadas na técnica de ELISA (Ensaio Imunoenzimático)

B.1.1. Tampão Fosfato Salina - PBS 20X

$\mathrm{NaCl}$ (Synth - Brasil)

$164,64 \mathrm{~g}$

$\mathrm{NaH} 2 \mathrm{PO} 4 \mathrm{H} 2 \mathrm{O}$ (Merck - Alemanha)

$7,16 \mathrm{~g}$

Na2HPO4 (Merck - Alemanha)

$21,02 \mathrm{~g}$

Água destilada

$1 \mathrm{~L}$

Em um becker dissolvem-se todos os sais em $600 \mathrm{~mL}$ de água destilada sob agitação contínua para dissolver totalmente os sais; acrescenta-se água destilada até completar $1 \mathrm{~L}$ e ajusta-se o pH entre 7.2 e 7.4.

\section{B.1.2. PBS 1X}

PBS 20X

$50 \mathrm{~mL}$

Água destilada

$950 \mathrm{~mL}$

\section{B.1.3. Tampão de Lavagem Tris/HCl}

Tris base (Calbiochem - Canadá)

$6.055 \mathrm{gr}$

$\mathrm{HCl}$ (coloca-se até acertar o pH)

Água destilada

$1 \mathrm{~L}$ 


\section{Anexo C}

C. 1. Soluções utilizadas na Técnica de Eletroforese em Gel de Poliacrilamida

\section{C.1.1. Solução Bis-acrilamida}

Acrilamida 30\% (Sigma - EUA) 30g

Bis-Acrilamida (Sigma - EUA) $1 \mathrm{~g}$

Água destilada 100mL

Homogeneiza-se a acrilamida e bis-acrilamida em $50 \mathrm{~mL}$ de água destilada em becker envolto com papel alumínio. Acerta-se o volume para 100,0mL, filtra-se em funil com papel filtro. Estoca-se a $4^{\circ} \mathrm{C}$ em frasco âmbar envolto em papel alumínio. Esta solução pode ser conservada por um período de 3 a 4 meses.

\section{C.1.2. Solução de Tris/ $\mathrm{HCl}$ a $1,5 \mathrm{M}$, pH 8.8}

Tris base (Calbiochem - Canadá) 90,82g

Água destilada $\quad 500 \mathrm{~mL}$

Em um balão volumétrico dissolve-se o Tris em $400 \mathrm{~mL}$ de água e completase para $500 \mathrm{~mL}$. Ajusta-se o $\mathrm{pH}$ para 8.8 . Estoca-se a $4^{\circ} \mathrm{C}$.

\section{C.1.3. Solução de Tris/HCl a $1 \mathrm{M}$, $\mathrm{pH} 6.8$}

Tris base (Calbiochem - Canadá) 60,65g

Água destilada $\quad 500 \mathrm{~mL}$

Em um balão volumétrico dissolve-se o Tris em 400mL de água e completase para $500 \mathrm{~mL}$. Ajusta-se o $\mathrm{pH}$ para 6.8. Estoca-se a $4^{\circ} \mathrm{C}$. 


\section{C.1.4. Solução de Persulfato de Amônia 10\%}

Persulfato de amônia - Plus One (GE - EUA) 1g

Água destilada $\quad 100 \mathrm{~mL}$

Distribui-se em alíquotas e se mantém congelado a $-20^{\circ} \mathrm{C}$.

\section{C.1.5. Tampão de amostra (Laemmli) $2 \mathrm{X}$}

10\% SDS (Gibco BRL - EUA) $\quad 40 \mathrm{~mL}$

$1 \mathrm{M}$ Tris/ $\mathrm{HCl} \mathrm{pH} 6.8 \quad 16 \mathrm{~mL}$

Glicerol (Invitrogen - EUA) 20mL

Azul de Bromofenol (Sigma - EUA) colocar aos poucos

Água destilada $\quad 14 \mathrm{~mL}$

Dilui-se em balão volumétrico e adiciona-se aos poucos o azul de bromofenol até obter uma coloração azul claro.

Para usar o tampão de amostra $1 \mathrm{X}$, adicionar $100 \mu \mathrm{L}$ do tampão de amostra em $900 \mu \mathrm{L}$ de 2-mercaptoetanol em tubo tipo Eppendorf de 1,5mL. Estoca-se a $-20^{\circ} \mathrm{C}$.

\section{C.1.6. Solução de Dodecil Sulfato de Sódio (SDS) a $10 \%$} SDS (Gibco BRL - EUA) $\quad 1 \mathrm{~g}$

Água destilada $\quad 100 \mathrm{~mL}$

Dissolve-se o SDS em água destilada, e estoca-se a $4^{\circ} \mathrm{C}$. 


\section{C.1.7. Tampão de Corrida}

Glicina (Sigma - EUA)

$58 g$

Tris base (Gibco BRL - EUA)

SDS (Gibco BRL - EUA)

Água destilada

$2 \mathrm{~L}$

Dissolve-se em $1 \mathrm{~L}$ de água destilada a glicina e o tris base, homogeniza-se e acerta-se o $\mathrm{pH}$ da solução para 8,3. Adicionam-se os $2 \mathrm{~g}$ de SDS, homogeniza-se até completar a dissolução. Completa-se para 2L.

\section{C.1.8. Gel de separação na concentração de $10 \%$ de acrilamida.}

Água destilada

Solução de bis-acrilamida (Sigma - EUA)

Tris/ $\mathrm{HCl} 1,5 \mathrm{M}$

Persulfato de amônia - Plus One (GE - EUA) $\quad 100 \mu \mathrm{L}$

Temed - Plus One (GE - EUA)

$10 \%$ SDS (Gibco BRL - EUA)

Dissolve-se a água destilada, o Tris/ $\mathrm{HCl}$ e a solução de bis-acrilamida, homogenizando-se bem. Adiciona-se o 10\% SDS, o persulfato de amônia e o TEMED, homogeniza-se bem e coloca-se na placa de vidro.

\section{C.1.9. Gel de empilhamento}

Água destilada

$14,16 \mathrm{~mL}$ (volume final de $20 \mathrm{~mL}$ )

Solução de bis-acrilamida

$3,32 \mathrm{ml}$
$4,15 \mathrm{~mL}$

$3,35 \mathrm{~mL}$

$2,5 \mathrm{~mL}$

$10 \mu \mathrm{L}$

$100 \mu \mathrm{L}$ 
1,0M Tris/HCl pH 6.8

$2,52 \mathrm{~mL}$

Para $5 \mathrm{ml}$ desta mistura, adiciona-se $100 \mu \mathrm{L}$ de persulfato de amônia, $100 \mu \mathrm{L}$ de SDS (10\%) e 10 $\mathrm{LL}$ de TEMED, homogenizando-se bem. Coloca-se devagar na placa de vidro para que não apareçam bolhas, colocando-se o pente. Retira-se o pente após a polimerização.

\section{C.1.10. Coloração pelo Brilhante Blue}

Azul Brilhante de Coomassie R-250 (Sigma) $5 \mathrm{~g}$

Ácido Acético Glacial (Merck)

$100 \mathrm{~mL}$

Metanol (Merck)

$450 \mathrm{~mL}$

Água destilada

$450 \mathrm{~mL}$

Em um balão volumétrico adiciona-se o ácido acético glacial e o etanol, completando-se para $1 \mathrm{~L}$ com água destilada. Adiciona-se o corante. Homogeniza-se lentamente em agitador magnético até completa dissolução do corante. Filtra-se e estoca-se em frasco âmbar à temperatura ambiente.

\section{C.1.11. Solução Descorante}

Ácido Acético Glacial (Merck) 70mL

Metanol (Merck) 250mL

Água destilada $\quad 680 \mathrm{~mL}$

Em um balão volumétrico adiciona-se o ácido acético glacial e o etanol, completando-se para $1 \mathrm{~L}$ com água destilada. Homogeniza-se lentamente em agitador magnético. Filtra-se e estoca-se em frasco âmbar à temperatura ambiente. 


\section{Anexo D}

Tabela 5 - Fenotipagem celular para o grupo Controle

\begin{tabular}{|c|c|c|c|c|c|c|c|}
\hline & CD3+ & CD4+ & CD8+ & CD19+ & CD3-CD56+ & CD3+CD56+ & CD206 \% \\
\hline Número de indivíduos & 9 & 9 & 9 & 9 & 9 & 9 & 19 \\
\hline Mínimo & 787,0 & 472,0 & 309,0 & 98,0 & 138,0 & 11,0 & 1,5 \\
\hline Percentil 25\% & 1221,0 & 733,0 & 407,5 & 244,5 & 179,5 & 25,0 & 4,3 \\
\hline Mediana & 1572,0 & 1016,0 & 446,0 & 298,0 & 206,0 & 43,0 & 9,4 \\
\hline Percentil 75\% & 1834,0 & 1278,0 & 540,0 & 406,5 & 276,0 & 72,0 & 15,1 \\
\hline Máximo & 2045,0 & 1532,0 & 574,0 & 493,0 & 298,0 & 110,0 & 18,2 \\
\hline Média & 1511,0 & 1002,0 & 455,6 & 307,9 & 217,8 & 50,7 & 9,2 \\
\hline Desvio Padrão & 390,8 & 335,3 & 85,2 & 117,7 & 53,9 & 31,5 & 5,4 \\
\hline Erro Padrão & 130,3 & 111,8 & 28,4 & 39,2 & 18,0 & 10,5 & 1,2 \\
\hline Intervalo de Confiança abaixo de $95 \%$ & 1211,0 & 744,2 & 390,1 & 217,4 & 176,4 & 26,5 & 6,6 \\
\hline Intervalo de Confiança acima de $95 \%$ & 1812,0 & 1260,0 & 521,1 & 398,3 & 259,2 & 74,9 & 11,8 \\
\hline \multicolumn{8}{|l|}{ Teste de Normalidade } \\
\hline Distância de KS & 0,1 & 0,1 & 0,2 & 0,2 & 0,2 & 0,2 & 0,2 \\
\hline Valor de P & $P>0.10$ & $P>0.10$ & $P>0.10$ & $P>0.10$ & $P>0.10$ & $P>0.10$ & $P>0.10$ \\
\hline Passou no teste de normalidade $\left({ }^{*}=0.05\right) ?$ & $\operatorname{Sim}$ & $\operatorname{Sim}$ & $\operatorname{Sim}$ & $\operatorname{Sim}$ & $\operatorname{Sim}$ & $\operatorname{Sim}$ & Sim \\
\hline Resumo do valor $\mathbf{P}$ & ns & ns & ns & ns & ns & ns & ns \\
\hline Coeficiente de variação & $25.85 \%$ & $33.47 \%$ & $18.70 \%$ & $38.22 \%$ & $24.74 \%$ & $62.10 \%$ & $58.50 \%$ \\
\hline Média Geométrica & 1460,0 & 948,2 & 448,2 & 283,4 & 211,8 & 41,4 & 7,5 \\
\hline
\end{tabular}

$\mathrm{CD}^{+}$: População total de linfócitos T; CD4 ${ }^{+}$: subpopulação de linfócitos T; CD8 ${ }^{+}$: subpopulação de linfócitos T; CD19+: população de células B; $\mathrm{CD}^{+} 6^{+}$: população de NK; CD206' receptor de manose; ns: não significante. 
Tabela 6 - Fenotipagem celular para o grupo de Pacientes com Dermatofitose Extensa

\begin{tabular}{lccccccc}
\hline & CD3+ & CD4+ & CD8+ & CD19+ & CD3-CD56+ & CD3+CD56+ & CD206 \% \\
\cline { 2 - 7 } Número de Indivíduos & 18 & 18 & 18 & 13 & 14 & 15 & 9 \\
Mínimo & 789 & 144 & 112 & 49 & 38 & 19 & 0,7 \\
Percentil 25\% & 1284 & 748,3 & 336,3 & 151,5 & 159,5 & 41 & 1,9 \\
Mediana & 1663 & 970 & 499,5 & 285 & 180,5 & 97 & 5,7 \\
Percentil 75\% & 2024 & 1226 & 873 & 461,5 & 245 & 226 & 12,7 \\
Máximo & 3452 & 2378 & 1146 & 578 & 437 & 339 & 29,8 \\
Média & 1745 & 1012 & 564,9 & 296,5 & 204,3 & 131,7 & 8,4 \\
Desvio Padrão & 700,4 & 516,4 & 284,3 & 173,7 & 100,7 & 102,4 & 9,2 \\
Erro Padrão & 165,1 & 121,7 & 67 & 48,2 & 26,9 & 26,4 & 3,1 \\
Intervalo de Confiança abaixo de 95\% & 1397 & 754,9 & 423,5 & 191,6 & 146,2 & 75 & 1,3 \\
Intervalo de Confiança acima de 95\% & 2093 & 1269 & 706,3 & 401,5 & 262,4 & 188,4 & 15,5 \\
Teste de Normalidade & & & & & & & \\
Distância de KS & 0,2 & 0,1 & 0,1 & 0,1 & 0,2 & 0,2 & 0,2 \\
P value & $>0.10$ & $>0.10$ & $>0.10$ & $>0.10$ & $>0.10$ & $>0.10$ & $>0.10$ \\
Passou no teste de normalidade (* $\left.{ }^{*}=\mathbf{0 . 0 5}\right) ?$ & Sim & Sim & Sim & Sim & Sim & Sim & Sim \\
Resumo do valor P & $\mathrm{ns}$ & $\mathrm{ns}$ & $\mathrm{ns}$ & $\mathrm{ns}$ & $\mathrm{ns}$ & $\mathrm{ns}$ & $\mathrm{ns}$ \\
Coeficiente de variação & $40.14 \%$ & $51.04 \%$ & $50.33 \%$ & $58.58 \%$ & $49.27 \%$ & $77.77 \%$ & $109.28 \%$ \\
Média Geométrica & 1624 & 866,6 & 490,9 & 233,1 & 178,6 & 90,8 & 4,9 \\
\hline
\end{tabular}

$\mathrm{CD}^{+}$: População total de linfócitos $\mathrm{T} ; \mathrm{CD}^{+}$: subpopulação de linfócitos $\mathrm{T} ; \mathrm{CD} 8^{+}$: subpopulação de linfócitos T; $C D 19^{+}$: população de células B; $\mathrm{CD}^{+} 6^{+}$: população de NK; CD206': receptor de manose; ns: não significante. 
Anexos

Tabela 7 - Análise dos Índices de Estimulação, das Culturas de Linfócitos de 6 dias, para o grupo Controle

\begin{tabular}{|c|c|c|c|c|c|c|c|c|c|c|}
\hline & CMA & PWM & P 1:6,25 & P 1:12,5 & P 1:25 & P 1:50 & $\mathrm{E} 40 \mu \mathrm{g}$ & $\mathrm{E} 20 \mu \mathrm{g}$ & $\mathrm{E} 10 \mu \mathrm{g}$ & $\mathrm{E} 5 \mu \mathrm{g}$ \\
\hline Número de Indivíduos & 19 & 19 & 11 & 14 & 14 & 14 & 12 & 12 & 12 & 12 \\
\hline Mínimo & 91,1 & 152,9 & 110,1 & 124,2 & 97,8 & 114,9 & 83,3 & 96 & 106,5 & 93,1 \\
\hline Percentil 25\% & 536,5 & 18885 & 202,3 & 177,9 & 169,6 & 193,2 & 122,8 & 187,4 & 175,1 & 166,8 \\
\hline Mediana & 7756 & 30361 & 259,5 & 347,8 & 245,5 & 283,9 & 486,3 & 530,6 & 393,1 & 503,3 \\
\hline Percentil 75\% & 16657 & 39798 & 742,1 & 1068 & 3231 & 932,3 & 1191 & 2533 & 1544 & 1225 \\
\hline Máximo & 64099 & 67486 & 3297 & 4320 & 7942 & 5554 & 11527 & 6927 & 9467 & 23668,0 \\
\hline Média & 10942 & 31022 & 696,8 & 821,9 & 1671 & 831,5 & 1707 & 1595 & 1344 & 2574 \\
\hline Desvio Padrão & 15760 & 17874 & 939 & 1133 & 2343 & 1424 & 3318 & 2279 & 2630 & 6668 \\
\hline Erro Padrão & 3616 & 4101 & 283,1 & 302,8 & 626,3 & 380,7 & 957,9 & 657,9 & 759,3 & 1925,0 \\
\hline Intervalo de Confiança abaixo de $95 \%$ & 3346 & 22407 & 66 & 167,8 & 317,9 & 9,1 & -401 & 147,5 & $-327,4$ & -1662 \\
\hline Intervalo de Confiança acima de $95 \%$ & 18538 & 39637 & 1328 & 1476 & 3024 & 1654 & 3816 & 3043 & 3015 & 6811 \\
\hline \multicolumn{11}{|l|}{ Teste de Normalidade } \\
\hline Distância de KS & 0,2 & 0,1 & 0,3 & 0,3 & 0,3 & 0,3 & 0,4 & 0,3 & 0,3 & 0,5 \\
\hline $\begin{array}{l}\text { P value } \\
\text { Passou no teste de normalidade }\end{array}$ & 0 & $>0.10$ & 0 & 0 & 0 & 0 & $<0.0001$ & 0 & 0 & $<0.0001$ \\
\hline$\left({ }^{*}=0.05\right) ?$ & Não & Sim & Não & Não & Não & Não & Não & Não & Não & Não \\
\hline Resumo do valor $\mathbf{P}$ & ** & ns & ** & ** & $* * *$ & $* * *$ & $* \star *$ & ** & $\star * *$ & $\star * *$ \\
\hline Coeficiente de variação & $144.03 \%$ & $57.62 \%$ & $134.76 \%$ & $137.85 \%$ & $140.24 \%$ & $171.31 \%$ & $\begin{array}{c}194.36 \\
\%\end{array}$ & $\begin{array}{c}142.84 \\
\%\end{array}$ & $\begin{array}{c}195.73 \\
\%\end{array}$ & $\begin{array}{c}259.02 \\
\%\end{array}$ \\
\hline Média Geométrica & 3028,0 & 21198,0 & 400,6 & 441,5 & 573,7 & 405,1 & 496,5 & 621 & 496,4 & 586,5 \\
\hline
\end{tabular}

CMA: Candida sp; PWM: mitógeno pokeweed; P: Peptídeo YIIDTGIDID; E: Extrato de Trichophyton rubrum; cpm: cintilações por minuto; ns: não significante. 
Tabela 8 - Dados individuais do ensaio de Linfoproliferação de células do sangue periférico do grupo Controle

\begin{tabular}{|c|c|c|c|c|c|c|c|c|c|c|c|}
\hline Indivíduos & CMA & PWM & P 1:6,25 & P 1:12,5 & P 1:25 & P 1:50 & $E 40 \mu g$ & 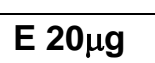 & $E 10 \mu g$ & E $5 \mu \mathrm{g}$ & $E 2,5 \mu \mathrm{g}$ \\
\hline$I$ & 2,00 & 1,00 & & 1,00 & 1,00 & 1,00 & & & & & \\
\hline II & 71,00 & 113,00 & & 1,00 & 1,00 & 1,00 & & & & & \\
\hline III & 2,00 & 297,00 & & 1,00 & 1,00 & 2,00 & & & & & \\
\hline IV & 58,00 & 385,00 & 2,00 & 3,00 & 1,00 & 2,00 & & & & & \\
\hline $\mathbf{v}$ & 58,00 & 280,00 & 1,00 & 1,00 & 1,00 & 1,00 & & & & & \\
\hline VI & 416,00 & 314,00 & 1,00 & 1,00 & 1,00 & 1,00 & & & & & \\
\hline VII & 77,00 & 152,00 & 1,00 & 7,00 & 30,00 & 2,00 & & & & & \\
\hline VIII & 2,00 & 24,00 & 1,00 & 1,00 & 3,00 & 2,00 & 6,00 & 4,00 & 3,00 & 3,00 & 3,00 \\
\hline IX & 6,00 & 39,00 & 2,00 & 3,00 & 3,00 & 3,00 & 7,00 & 3,00 & 5,00 & 14,00 & 4,00 \\
\hline$x$ & 1,00 & 28,00 & 1,00 & 2,00 & 1,00 & 1,00 & 1,00 & 1,00 & 1,00 & 2,00 & 2,00 \\
\hline $\mathbf{X I}$ & 12,00 & 27,00 & 1,00 & 0,00 & 4,00 & 1,00 & 1,00 & 7,00 & 2,00 & 1,00 & 1,00 \\
\hline XII & 2,00 & 25,00 & 2,00 & 2,00 & 5,00 & 1,00 & 1,00 & 2,00 & 1,00 & 2,00 & 1,00 \\
\hline XIIII & 51,00 & 92,00 & 1,00 & 0,00 & 1,00 & 1,00 & 1,00 & 1,00 & 1,00 & 1,00 & 0,00 \\
\hline XIV & 55,00 & 319,00 & 2,00 & 1,00 & 1,00 & 1,00 & 1,00 & 1,00 & 1,00 & 1,00 & 1,00 \\
\hline$x V$ & 157,00 & 148,00 & & & & & 1,00 & 1,00 & 1,00 & 1,00 & 1,00 \\
\hline $\mathrm{XVI}$ & 2,00 & 118,00 & & & & & 1,00 & 1,00 & 1,00 & 1,00 & 1,00 \\
\hline XVII & 2,00 & 54,00 & & & & & 1,00 & 1,00 & 1,00 & 1,00 & 1,00 \\
\hline XVIII & 1,00 & 54,00 & & & & & 1,00 & 1,00 & 1,00 & 1,00 & 1,00 \\
\hline XIX & 1,00 & 30,00 & & & & & 1,00 & 1,00 & 1,00 & 1,00 & 1,00 \\
\hline
\end{tabular}

CMA: Candida sp; PWM: mitógeno pokeweed; P: Peptídeo YIIDTGIDID; E: Extrato de Trichophyton rubrum; cpm: cintilações por minuto; ns: não significante. 
Tabela 9 - Índices de Estimulação, das Culturas de Linfócitos de 6 dias, para o grupo de Pacientes com Dermatofitose Extensa

\begin{tabular}{|c|c|c|c|c|c|c|c|c|c|c|c|c|}
\hline & CMA & PWM & P1: 6,25 & P1: 12,5 & P1: 25 & P1: 50 & P1: 100 & E 40ug & 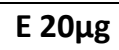 & 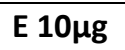 & 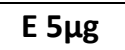 & E 2,5 $\mu \mathrm{g}$ \\
\hline Números de Indivíduos & 8 & 8 & 8 & 7 & 7 & 7 & 7 & 8 & 8 & 8 & 8 & 8 \\
\hline Mínimo & 7,75 & 0,24 & 0 & 0 & 0,36 & 0,35 & 0,68 & 0,34 & 0,27 & 0,29 & 0 & 7,75 \\
\hline Percentil 25\% & 26,74 & 1,163 & 0 & 0 & 0,6 & 0,52 & 0,89 & 0,7925 & 0,7075 & 0,7425 & 0,385 & 26,74 \\
\hline Mediana & 31,21 & 1,195 & 0,44 & 0,62 & 0,75 & 0,77 & 0,9 & 1,75 & 1,505 & 1,55 & 0,84 & 31,21 \\
\hline Percentil 75\% & 60,08 & 12 & 0,8075 & 0,91 & 1 & 0,96 & 1,05 & 5,785 & 4,503 & 4,578 & 2,623 & 60,08 \\
\hline Máximo & 213,5 & 27,06 & 2,47 & 1,02 & 1,15 & 1,17 & 1,11 & 40,64 & 31,68 & 28,38 & 23,14 & 213,5 \\
\hline Média & 57 & 6,636 & 0,6075 & 0,4929 & 0,7671 & 0,75 & 0,9286 & 7,104 & 5,668 & 5,161 & 3,841 & 57 \\
\hline Desvio Padrão & 65,47 & 9,447 & 0,8196 & 0,4143 & 0,2624 & 0,2905 & 0,138 & 13,7 & 10,63 & 9,513 & 7,855 & 65,47 \\
\hline Erro Padrão & 23,15 & 3,34 & 0,2898 & 0,1566 & 0,09918 & 0,1098 & 0,05216 & 4,843 & 3,76 & 3,363 & 2,777 & 23,15 \\
\hline \multicolumn{13}{|l|}{ Intervalo de Confiança abaixo de } \\
\hline $95 \%$ & 2,268 & $-1,262$ & $-0,07775$ & 0,1097 & 0,5245 & 0,4814 & 0,8009 & $-4,348$ & $-3,223$ & $-2,792$ & $-2,726$ & 2,268 \\
\hline \multicolumn{13}{|l|}{ Coeficiente de Variação } \\
\hline Média Geométrica & 0,347 & 0,3421 & 0,254 & 0,192 & 0,1192 & 0,183 & 0,2471 & 0,3978 & 0,415 & 0,3755 & 0,4297 & 0,347 \\
\hline
\end{tabular}

CMA: Candida sp; PWM: mitógeno pokeweed; P: Peptídeo YIIDTGIDID; E: Extrato de Trichophyton rubrum; cpm: cintilações por minuto; ns: não significante. 
Tabela 10 - Dados individuais do ensaio de Linfoproliferação de 6 dias, para o grupo de Pacientes com Dermatofitose Extensa

\begin{tabular}{cccccccccccc}
\hline Indivíduos & PWM & CMA & TT & P 1:6,25 & P 1:12,5 & P 1:25 & P 1:50 & E40 $\boldsymbol{\mu g}$ & E20 $\boldsymbol{\mu g}$ & E10 $\boldsymbol{\mu g}$ & E5 $\boldsymbol{\mu g}$ \\
\hline I & 7,75 & 13,47 & 0 & 0 & 0,66 & 0,55 & 0,9 & 6,32 & 4,6 & 5,15 & 2,76 \\
II & 29,38 & 0,24 & 0,39 & 0,26 & 0,36 & 0,35 & 0,9 & 0,34 & 0,27 & 0,29 & 0,3 \\
III & 55,51 & 7,6 & 0 & 0,91 & 0,75 & 1,17 & 1,11 & 4,18 & 4,21 & 2,86 & 2,21 \\
IV & 30,98 & 1,16 & 0 & 0 & 1 & 0,52 & 0,89 & 1,93 & 1,81 & 1,98 & 0 \\
V & 61,6 & 1,18 & 0,86 & 0,62 & 1,15 & 0,93 & 0,97 & 1,57 & 0,94 & 0,73 & 0,64 \\
VI & 31,43 & 27,06 & 2,47 & 0,64 & 0,85 & 0,96 & 1,05 & 40,64 & 31,68 & 28,38 & 23,14 \\
VII & 25,86 & 1,21 & 0,65 & & & & & 1,19 & 1,2 & 1,12 & 1,01 \\
VIII & 213,49 & 1,17 & 0,49 & 1,02 & 0,6 & 0,77 & 0,68 & 0,66 & 0,63 & 0,78 & 0,67 \\
\hline
\end{tabular}

CMA: Candida sp; PWM: mitógeno pokeweed; P: Peptídeo YIIDTGIDID; E: Extrato de Trichophyton rubrum; cpm: cintilações por minuto; ns: não significante. 
Tabela 11 - Dados individuais de quantificação de citocina IL-4 do grupo Controle

\begin{tabular}{cccccc}
\hline Indivíduos & Basal & PHA & Basal & CMA & P 1:25 \\
\hline I & 0,00 & 76,85 & 0,00 & & 7,53 \\
II & 0,00 & 0,00 & 0,00 & 0,00 & 2,05 \\
III & 0,00 & 79,83 & 15,78 & 5,47 & 30,45 \\
IV & 0,00 & 159,58 & 0,00 & 6,16 & 5,47 \\
V & 7,53 & 21,34 & 10,26 & 0,00 & 6,16 \\
VI & 0,00 & 6,84 & 0,00 & 0,00 & 0,00 \\
\hline
\end{tabular}

PHA: mitógeno da Fitohemaglutinina; CMA: antígeno metabólico de Candida ssp; P: peptídeo YIIDTGIDID.

Tabela 12 - Dados individuais de quantificação de citocina IL-4 para o grupo de Pacientes com Dermatofitose Extensa

\begin{tabular}{cccccc}
\hline Indivíduos & Basal & PHA & Basal & CMA & P 1:25 \\
\hline I & 0,00 & 27,62 & & 4,11 & 4,79 \\
II & 0,00 & 0,00 & 0,00 & 0,68 & 80,57 \\
III & 0,00 & 99,54 & 9,58 & 4,11 & 6,16 \\
IV & 0,00 & 7,53 & 0,00 & 1,37 & 0,68 \\
V & 0,68 & 35,40 & 0,00 & 5,47 & 0,00 \\
VI & 0,00 & 0,00 & 10,95 & 0,00 & 6,16
\end{tabular}

PHA: mitógeno da Fitohemaglutinina; CMA: antígeno metabólico de Candida ssp; P: peptídeo YIIDTGIDID. 
Tabela - 13: Dados individuais de quantificação de citocina IL-10 do grupo Controle

\begin{tabular}{cccccc}
\hline Indivíduos & Basal & PHA & Basal & CMA & P 1:25 \\
\hline I & 1115,83 & 1282,72 & 492,35 & 64,11 & 1134,72 \\
II & 2076,23 & & 1635,39 & 996,17 & 1414,97 \\
III & 2022,70 & 826,13 & 1528,33 & 797,79 & 832,43 \\
IV & 3024,04 & 2114,02 & 3282,25 & 1285,87 & 1767,64 \\
V & 3716,79 & 1720,41 & 2970,51 & 1465,35 & 2003,81 \\
VI & 5184,16 & 5788,74 & 3741,98 & 974,13 & 1147,32 \\
VII & 70,00 & 66,80 & 132,61 & 55,76 & 58,76 \\
VIII & 0,00 & 0,00 & 1361,44 & 0,00 & 552,18 \\
IX & 851,32 & 212,11 & 52,77 & 0,00 & 62,44 \\
X & 0,00 & 0,00 & 977,28 & 0,00 & 441,97
\end{tabular}

PHA: mitógeno da Fitohemaglutinina; CMA: antígeno metabólico de Candida ssp; P: peptídeo YIIDTGIDID.

Tabela - 14: Dados individuais de quantificação de citocina IL-10 para o grupo de Pacientes com Dermatofitose Extensa

\begin{tabular}{cccccc}
\hline Indivíduos & Basal & PHA & Basal & CMA & P 1:25 \\
\hline I & 1987,14 & 1203,52 & & 1040,65 & 1102,11 \\
II & 1603,01 & 779,44 & & 601,21 & 788,66 \\
III & & 1105,18 & 1664,47 & 711,84 & 807,10 \\
IV & 3363,85 & 1138,99 & 2881,39 & 358,44 & 687,25 \\
V & 1606,09 & 284,69 & 539,75 & 77,89 & 93,89 \\
VI & 0,00 & 0,00 & 1006,85 & 0,00 & 484,43 \\
\hline
\end{tabular}

PHA: mitógeno da Fitohemaglutinina; CMA: antígeno metabólico de Candida ssp;

P: peptídeo YIIDTGIDID. 
Tabela - 15: Dados individuais de quantificação de citocina IL-12 do grupo Controle

\begin{tabular}{cccccc}
\hline Indivíduos & Basal & PHA & Basal & CMA & P 1:25 \\
\hline I & 23,22 & 220,77 & 172,85 & 135,10 & 167,77 \\
II & 167,05 & 204,07 & 431,30 & 138,73 & 84,29 \\
III & 362,33 & 387,74 & 465,42 & 440,74 & 297,72 \\
IV & 331,84 & 577,22 & 147,45 & 89,37 & 197,54 \\
V & 81,38 & 90,82 & 272,31 & 123,49 & 237,47 \\
VI & 8,81 & 7,61 & 10,43 & 8,38 & 8,90 \\
VII & 19,60 & 8,62 & 7,47 & 7,95 & 15,78 \\
VIII & 0,00 & 0,00 & 2081,43 & 0,00 & 37,61 \\
IX & 15,23 & 26,22 & 8,23 & 0,00 & 8,28 \\
\hline
\end{tabular}

PHA: mitógeno da Fitohemaglutinina; CMA: antígeno metabólico de Candida ssp; P: peptídeo YIIDTGIDID.

Tabela - 16: Dados individuais de quantificação de citocina IL-12 para o grupo de Pacientes com Dermatofitose Extensa

\begin{tabular}{cccccc}
\hline Indivíduos & Basal & PHA & Basal & CMA & P1:25 \\
\hline I & 112,60 & 130,75 & 414,60 & 145,27 & 243,27 \\
II & 68,32 & 117,68 & 469,78 & 90,09 & 244,00 \\
III & 57,43 & 39,28 & 112,60 & 170,68 & 196,81 \\
IV & 7,61 & 328,94 & 8,04 & 7,99 & 8,52 \\
V & 292,64 & 10,15 & 7,75 & 8,95 & 8,23 \\
VI & 0,00 & 0,00 & 2238,24 & 0,00 & 0,29 \\
\hline
\end{tabular}

PHA: mitógeno da Fitohemaglutinina; CMA: antígeno metabólico de Candida ssp; P: peptídeo YIIDTGIDID. 
Tabela - 17: Dados individuais de quantificação de citocina IFN-gama do grupo Controle

\begin{tabular}{cccccc}
\hline Indivíduos & Basal & PHA & Basal & CMA & P 1:25 \\
\hline I & 52,19 & 4353,15 & 41,47 & 1121,57 & 1835,37 \\
II & 39,88 & 4121,30 & 26,13 & 68,06 & 362,50 \\
III & 29,71 & 5193,20 & 142,57 & 18,49 & 219,58 \\
IV & 69,56 & 1269,25 & 38,38 & 64,45 & 291,04 \\
V & 14,73 & 4001,41 & 46,13 & 1567,37 & 47,18 \\
VI & 311,43 & 2615,67 & 221,13 & 65,24 & 117,46
\end{tabular}

PHA: mitógeno da Fitohemaglutinina; CMA: antígeno metabólico de Candida ssp; P: peptídeo YIIDTGIDID.

Tabela - 18: Dados individuais de quantificação de citocina IFN-gama para o grupo de Pacientes com Dermatofitose Extensa

\begin{tabular}{cccccc}
\hline Indivíduos & Basal & PHA & Basal & CMA & P 1:25 \\
\hline I & 20,55 & 460,17 & 125,10 & 84,32 & 32,28 \\
II & 24,37 & 781,74 & 41,12 & 53,71 & 41,71 \\
III & 25,35 & 4619,14 & 36,24 & 59,39 & 57,50 \\
IV & 27,04 & 85,09 & 38,82 & 46,81 & 34,96 \\
V & 11,54 & 61,09 & 21,93 & 19,52 & 46,51 \\
VI & 0,00 & 0,00 & 32,74 & 0,00 & 25,82 \\
\hline
\end{tabular}

PHA: mitógeno da Fitohemaglutinina; CMA: antígeno metabólico de Candida ssp; P: peptídeo YIIDTGIDID. 
Anexo E

HOSPITAL DAS CLÍNICAS

DA

FACULDADE DE MEDICINA DA UNIVERSIDADE DE SÃO PAULO

TERMO DE CONSENTIMENTO PÓS -INFORMAÇÃO

(Instruções para preenchimento no verso)

I - DADOS DE IDENTIFICAÇÃO DO SUJEITO DA PESQUISA OU RESPONSÁVEL LEGAL

1.NOME DO PACIENTE:

DOCUMENTO DE IDENTIDADE № :

SEXO : $M[$ ] $F[$ ]

DATA NASCIMENTO: ........................

ENDEREÇO.

№.

APTO:

BAIRRO:

CIDADE

CEP:

TELEFONE: DDD (

...)..

2.RESPONSÁVEL LEGAL

NATUREZA (grau de parentesco, tutor, curador etc.)

DOCUMENTO DE IDENTIDADE : SEXO: M [ ] F [ ]

DATA NASCIMENTO.: .....................

ENDEREÇO:

№.

.APTO:

BAIRRO:

CIDADE:

CEP:

TELEFONE: DDD

II - DADOS SOBRE A PESQUISA CIENTÍFICA

1.TítULO dO PROTOCOLO DE PESQUISA: CARACTERIZAÇÃO DA RESPOSTA IMUNOLÓGICA CELULAR EM PACIENTES PORTADORES DE DERMATOFITOSES EXTENSAS

2.PESQUISADOR: Prof. Dr. Dewton de Moraes Vasconcelos 
CARGO/FUNÇÃO: Pesquisador Associado ao LIM56. INSCRIÇÃO CONSELHO REGIONAL № 41700 UNIDADE DO HCFMUSP: Laboratório de Investigação Médica - Unidade 56 3.AVALIAÇÃO DO RISCO DA PESQUISA:

$\begin{array}{lllll}\text { SEM RISCO } & \text { [ ] } & \text { RISCO MíNIMO } & \text { [ X ] } & \text { RISCO MÉdIO } \\ \text { RISCO BAIXo } & \text { [ ] } & \text { RISCO MAIOR } & \text { [ ] }\end{array}$

(probabilidade de que o indivíduo sofra algum dano como consequência imediata ou tardia do estudo)

4.DURAÇÃO DA PESQUISA : Dois anos 
III - REGISTRO DAS EXPLICAÇÕES DO PESQUISADOR AO PACIENTE OU SEU REPRESENTANTE LEGAL SOBRE A PESQUISA, CONSIGNANDO:

1. justificativa e objetivos da pesquisa ; 2. procedimentos que serão utilizados e propósitos, incluindo a identificação dos procedimentos que são experimentais; 3 . desconfortos e riscos esperados; 4. benefícios que poderão ser obtidos; 5 . procedimentos alternativos que possam ser vantajosos para o indivíduo.

Você está sendo convidado a participar voluntariamente (isto é, sem remuneração e de modo não obrigatório) de um estudo sobre a resposta imunológica na Dermatofitose extensa.

Caso você concorde, seu sangue será coletado periodicamente para a contagem de populações específicas de células chamadas LINFÓCITOS e dosagem de substâncias importantes na resposta imune chamadas CITOCINAS. Os riscos e desconforto envolvidos são os mesmos de uma coleta de sangue padrão no seguimento de pessoas com Dermatofitose extensa. $O$ possível benefício é o de um acompanhamento dentro de uma sistemática diferente da que é feita no ambulatório do HC. Você poderá ainda estar ajudando outras pessoas com o mesmo tipo de problema ao permitir a obtenção / análise de dados sobre a doença. Caso não concorde em participar, você possui a opção de manter o seu acompanhamento normal sem qualquer prejuízo dentro do HC. Você poderá ter acesso não só aos dados obtidos como também ao esclarecimento de qualquer assunto relacionado ao estudo. Os dados obtidos poderão ser acessados exclusivamente pelos investigadores, comissões de ética das instituições envolvidas e autoridades sanitárias do país.

Em caso de emergência e/ou dúvidas você poderá entra em contato com: 
IV - ESCLARECIMENTOS DADOS PELO PESQUISADOR SOBRE GARANTIAS DO SUJEITO DA PESQUISA:

1. acesso, a qualquer tempo, às informações sobre procedimentos, riscos e benefícios relacionados à pesquisa, inclusive para dirimir eventuais dúvidas.

2.liberdade de retirar seu consentimento a qualquer momento e de deixar de participar do estudo, sem que isto traga prejuízo à continuidade da assistência.

3.salvaguarda da confidencialidade, sigilo e privacidade.

4.disponibilidade de assistência no HCFMUSP, por eventuais danos à saúde, decorrentes da pesquisa.

5.viabilidade de indenização por eventuais danos à saúde decorrentes da pesquisa.

V - INFORMAÇÕES DE NOMES, ENDEREÇOS E TELEFONES DOS RESPONSÁVEIS PELO ACOMPANHAMENTO DA PESQUISA, PARA CONTATO EM CASO DE INTERCORRÊNCIAS CLÍNICAS E REAÇÕES ADVERSAS.

Dewton de Moraes Vasconcelos. Tel: 3061-7457 ou 3061-7499.

VI - OBSERVAÇÕES COMPLEMENTARES: 
VII - CONSENTIMENTO PÓS-ESCLARECIDO

Declaro que, após convenientemente esclarecido pelo pesquisador e ter entendido o que me foi explicado, consinto em participar do presente Protocolo de Pesquisa

São Paulo,

de de 


\title{
Anexo F
}

\author{
HOSPITAL DAS CLINICAS \\ FACULDADE DE MEDICINA DA UNIVERSIDADE DE SÃO PAULO \\ CAIXA POSTAL, 3671 \\ SÄO PAULO - BRASIL
}

DIRETORIA CLÍNICA

\section{Comissão de Ética para Análise de Projetos de Pesquisa}

\section{APROVAÇÃO}

A Comissão de Ética para Análise de Projetos de Pesquisa - CAPPesq da Diretoria Clínica do Hospital das Clínicas e da Faculdade de Medicina da Universidade de São Paulo, em sessão de 23.11.00, APROVOU o Protocolo de Pesquisa $n^{\circ}$ 855/00 intitulado: "Caracterização da resposta imunológica celular em pacientes portadores de dermatofitoses extensas", apresentado pelo(a) pesquisador(a) Prof. Dr. Dcwton de Moraes Vasconcelos, do Departamento de Dermatologia, bem como Termo de Consentimento Livre e Esclarecido.

CAPPesq, 24 de novembro de 2000.

PROF. DR. JORGE KALIL FILHO

Presidente da Comissão de Ética Para

Análise de Projetos de Pesquisa

OBSERVAÇÃO: Cabe ao pesquisador elaborar e apresentar à CAPPesq, os relatórios parciais e final sobre a pesquisa (Resolução do Conselho Nacional de Saúde $n^{\circ} 196$, de 10.10.1996, inciso IX.2, letra "c"). 


\section{Referências Bibliográficas}

Aderem A, Ulevitch $R$. Toll-like receptors in the induction of the innate immune response. Nature. 2000; 406(6797):782-7.

Akira S, Takeda K. Toll-like receptor signaling. Nat Rev Immunol. 2004; 4(7):499-511 .

Allen, D.E.; Snyderman R, Meadows L, Pinnell SR. Generalized Microsporum audouinii infection and depressed cellular immunity associated with a missing plasma factor required for lymphocyte blastogenesis. Am J Med. 1977; 63(6):991 - 1000.

Almeida SR. Immunology of Dermatophytosis. Mycopathologia. 2008; 166(56):277-83.

Beutler B. Innate immunity: an overview. Mol Immunol. 2004; 40(12):845-59.

Blake JS, Dahl MV, Herron MJ, Nelson RD. An Immunoinhibitory Cell Wall Glycoprotein (Mannan) from Trichophyton rubrum. J Invest Dermatol. 1991; 96(5):657-61 .

Bullock, W.E.; Wong, B. Fungi: immunologic aspects of infectious disease. Samter's Immunologic Diseases. M. M. A. Frank, K.F.; Claman, H.N.; Unanue, E.R.. Boston, Little, Brown and Company, p.1413-1415, 1995.

Calderon, R.A. Immunoregulation of dermatophytosis. Crit Rev Microbiol. 1989; 16(5):339-68.

Chinelli PAV, Sofiatti AA, Nunes RS, Martins JEC. Dermatophyte Agents in the City of São Paulo, from 1992 to 2002. Rev. Inst. Med. trop. S. Paulo, 2003; 45:259-263. 
Davison F.D.; Mackenzie D.W.R. DNA homology studies in the taxonomy of dermatophytes. Sabouraudia. 1984; 22(2):117-23.

De Vroey C. Epidemiology of ringworm (dermatophytosis). Semin. Dermatol. $1985 ; 4: 185-200$.

Djawari D, Bischoff T, Hornstein OP. Impairment of chemotactic activity of macrophages in chronic mucocutaneeous candidosis. Arch Dermatol Res. 1978; 262(3):247-53.

Drummond, R., A, Saijo, S., Iwakura, Y., Brown, G., D. The role of Syk/CARD9 coupled C-type lectins in antifungal immunity. Eur J Immunol. $2011 ; 41(2): 276-81$.

Durandeau LPS, Carmona SMC, Siwady JGS, JR HA. Chronic mucocutaneous candidiasis. Cutaneous expression of immunologic anomalies. Report of a case. Med Cutan Ibero Lat Am. 1986; 14(5):357-63.

Engering AJ, Cella M, Fluitsma D, Brockhaus M, Hoefsmit EC, Lanzavecchia A, Pieters J. The mannose receptor functions as a high capacity and broad specificity antigen receptor in human dendritic cells. Eur J Immunol. 1997; 27(9):2417-25.

Esquenazi D, Alviano CS, de Souza W, Rozental S. The influence of surface carbohydrates during in vitro infeccion of mammalian cells by the dermatophyte Trichophyton rubrum. Res Microbiol. 2004; 155(3):144-53.

Figdor CG, van Kooyk Y, Adema GJ. C-type lectin receptors on dendritic cells and Langerhans cells. Nat Rev Immunol. 2002; 2(2):77-84. 
Grando SA, Hostager BS, Herron MJ, Dahl MV, Nelson RD.. Binding of Trichophyton rubrum Mannan to Human Monocytes in vitro. J Invest Dermatol. 1992; 98(6):876-80.

Grappel, S.F.; Blank, F.; Bishop, C.T. Immunology of dermatophytes and dermatophytosis. Bacteriol Rev. 1974; 38(2):222-50.

Gentles JC, Evans EGV. Foot infections in swimming baths. Br Med J. 1973; 3(5874):260-2.

Geijtenbeek TBH, Gringhuis SI. Signalling through C $\square$ type lectin receptors: shaping immune responses. Nat Rev Immunol. 2009; 9(7):465-79.

Goodridge, H. S., Wolf, A. J., Underhill, D. M. $\beta$-glucan recognition by the innate immune system. Immunol Rev. 2009; 230(1):38-50.

Hay, R.J. Tinea imbricata. In: Current topics in medical mycology II. New York, Springer - Verlag. 1987. p.55- 72.

Hay, R.J.; et al. Immune responses of patients with tinea imbricata. $\mathrm{Br} \mathrm{J}$ Dermatol. 1983;108, p.581 - 589 .

Hay, R.J. Dermatophytosis and other superficial mycosis. In: Principles and practice of infectious diseases. 4th ed. New York, Churchill-Livingstone. p.2375 -2386 .

Heinzel FP, Sadick MD, Holaday BJ, Coffman RL, Locksley RM. Reciprocal -4 during the resolution or progression of murine leishmaniasis: evidence for expansion of distinct T helper cell subsets. J Exp Med. 1989; 169(1):59-72. Hoebe K, Janssen E, Beutler B. The interface between innate and adaptative immunity. Nat Immunol. 2004; 5(10):971-4. 
Hollming ST, Ariizumi K, Cruz PDJr. Recognition of non-selfpolyssaccharidesby C-type lectin receptors dectin-1 and dectin-2. Glycobiology. $2009 ; 19(6): 568-75$.

Ive F.A. The carrier state of tinea capitis in Nigeria. Br J Dermatol. 1966; 78(4):219-21 .

Jeffries C.D.; Reiss E.; Ajello L. Analytical isoelectric focusing of secreted dermatophyte proteins applied to taxonomic differentiation of Microsporum and Trichophyton species (preliminary studies). Sabouraudia. 1984; 22(5):369-79. Jones HE, Reinhardt JH, Rinaldi MG. Acquired immunity to dermatophytosis. Arch Dermatol. 1974; 109(6):840-8.

King RD, Khan HA, Foye JC, Greenberg JH, Jones HE. Transferrin, iron, and dermatophytes. I. Serum dermatophyte inhibitory component definitively identified as unsaturated transferrin. J Lab Clin Med. 1975; 86(2):204-12.

Laemmli UK. Cleavage of structural proteins during the assembly of the head of bacteriophage T4. Nature. 1970; 227(5259):680-5.

MacGregor JM, Hamilton A, Hay RJ. Possible mechanisms of immune modulation in chronic dermatophytosis - an in vitro study. Br J Dermatol. 1992; 127(3):233-8.

Maggi E, Parronchi P, Manetti R, Simonelli C, Piccinni MP, Rugiu FS, De Carli M, Ricci M, Romagnani S. Reciprocal regulatory effects of IFN-gamma and IL-4 on the in vitro development of human Th1 and Th2 clones. J Immunol. $1992 ; 148(7): 2142-7$. 
McGreal EP, Miller JL, Gordon S. Ligand recognition by antigen-presenting cell C-type lectin receptors. Curr Opin Immunol. 2005; 17(1):18-24.

Miyake, Y., Ishikawa, E., Ishikawa., T., Yamasaki, S. Self and nonself recognition through C-type lectin receptor, Mincle. Self Nonself. 2010; 1(4):310313.

Mora-Montes HM, Netea MG, Ferwerda G, Lenardon mD, Brown GD, Mistry

AR, Kullberg BA, O'Callanghan CA, Sheth CC, Odds FC, Brown AJP, Munro

CA, Gow NAR. Recognition and Blocking of Innate Immunity Cells by Candida albicans Chitin. Infect Immun. 2011; 79(5):1961-70.

Moraes-Vasconcelos, D.; Duarte, A.J.S. Caracterização da Competência Imunológica de Pacientes Portadores de Candidíase Mucocutânea Crônica. [Tese]. São Paulo: Instituto de Ciências Biomédicas da Universidade de Sâo Paulo; 1998.

Ning J, Heng L, Kong F. A highly efficient synthesis of an octasaccharide, the repeating unit of the cell-wall mannan of Trichophyton mentagrophytes and $\mathrm{T}$. rubrum. Carbohydr Res. 2002; 337(13):1159-64.

Rippon JW. Epidemiology and emerging patterns of dermatophyte species. In: Current topics in medical mycology I. Springer-Verlag, New York. 1985:288 334.

Ruland, J. CARD9 Signaling in the Innate Immune Response. Ann N Y Acad Sci. 2008; 1143:35-44.

Saijo, S., Iwakura, Y. Dectin-1 and Dectin-2 in innate immunity against fungi. Int Immunol. 2011; 23(8):467-72. 
Saijo, S., Ikeda, S., Yamabe, K., Kakuta, S., Ishigame, H.,Akitsu, A., Fujikado, N., Kusaka, T., Kubo, S., Chung, S., Komatsu, R., Miura, N., Adachi, Y., Ohno, N., Shibuya, K., Yamamoto, N., Kawakami, K., Yamasaki, S., Saito, T., Akira, S., Iwakura, Y. Dectin-2 Recognition of a-Mannans and Induction of Th17 Cell Differentiation Is Essential for Host Defense against Candida albicans. Immunity. 2010; 32(5):681-91.

Schoenen H, Bodendorfer B, Hitchens K, Manzanero S, Werninghaus K, Nimmerjahn F, Agger EM, Stenger S, Andersen P, Ruland J, Brown GD, Wells C, Lang R. Cutting Edge: Mincle Is Essential for Recognition and Adjuvanticity of the Mycobacterial Cord Factor and its Synthetic Analog TrehaloseDibehenate. J Immunol. 2010; 184(6):2756-60.

Scott P, Pearce E, Cheever AW, Coffman RL, Sher A. Role of cytokines and CD4+ T-cell subsets in the regulation of parasite immunity and disease. Immunol Rev. 1989; 112:161-82.

Seaman WE. Host defense mechanism and inflammation - natural killer cells. Principles and Practice. R. R. F. Rich, T.A.; Schwartz, B.D.; Shearer, W.T.; Strober, W.. New York, Mosby-Year Book: 282-289, 1996.

Sergeantson S, Lawrence G. Autosomal recessive inheritance of susceptibility to tinea imbricata. Lancet. $1977 ; 1$ (8001):13-5.

Sher A, Gazzinelli RT, Oswald IP, Clerici M, Kullberg M, Pearce EJ, Berzofsky JA, Mosmann TR, James SL, Morse HC 3rd. Role of T-cell derived cytokines in the down regulation of immune responses in parasitic and retroviral infection. Immunol Rev. 1992; 127:183-204. 
Saijo, S., Ikeda, S., Yamabe, K., Kakuta, S., Ishigame, H.,Akitsu, A., Fujikado, N., Kusaka, T., Kubo, S., Chung, S., Komatsu, R., Miura, N., Adachi, Y., Ohno, N., Shibuya, K., Yamamoto, N., Kawakami, K., Yamasaki, S., Saito, T., Akira, S., Iwakura, Y. Dectin-2 Recognition of a-Mannans and Induction of Th17 Cell Differentiation Is Essential for Host Defense against Candida albicans. Immunity. 2010; 32(5):681-91.

Schoenen H, Bodendorfer B, Hitchens K, Manzanero S, Werninghaus K, Nimmerjahn F, Agger EM, Stenger S, Andersen P, Ruland J, Brown GD, Wells C, Lang R. Cutting Edge: Mincle Is Essential for Recognition and Adjuvanticity of the Mycobacterial Cord Factor and its Synthetic Analog TrehaloseDibehenate. J Immunol. 2010; 184(6):2756-60.

Scott P, Pearce E, Cheever AW, Coffman RL, Sher A. Role of cytokines and CD4+ T-cell subsets in the regulation of parasite immunity and disease. Immunol Rev. 1989; 112:161-82.

Seaman WE. Host defense mechanism and inflammation - natural killer cells. Principles and Practice. R. R. F. Rich, T.A.; Schwartz, B.D.; Shearer, W.T.; Strober, W.. New York, Mosby-Year Book: 282-289, 1996.

Sergeantson S, Lawrence G. Autosomal recessive inheritance of susceptibility to tinea imbricata. Lancet. $1977 ; 1$ (8001):13-5.

Sher A, Gazzinelli RT, Oswald IP, Clerici M, Kullberg M, Pearce EJ, Berzofsky JA, Mosmann TR, James SL, Morse HC 3rd. Role of T-cell derived cytokines in the down regulation of immune responses in parasitic and retroviral infection. Immunol Rev. 1992; 127:183-204. 
Souza, V. M.; Gambale, V. Obtenção de Extratos Brutos com Líquido de Coca, Tris-HCL e Etileno-Glicol de Trichophyton mentagrophytes Var. Antropofílica Cultivado em Vários Substratos. [Dissertação]. São Paulo: Instituto de Ciências Biomédicas, Universidade de São Paulo; 1993.

Svejgaard E, Lowenstein H. Trichophyton rubrum specific IgE antibodies in serum from patients with chronic dermatophytosis demonstrated by crossed radial - immunoelectrophoresis. Acta Derm Venereol Suppl (Stockh). 1985; 120:72-5.

Svejgaard, E. Recent trends in the immunology of dermatophytosis. Microbiol Sci. 1986; 3(5):154-9.

Takeda K., Kaisho, T., Akira, S. Toll-like receptors. Annu Rev Immunol. 2003; $21: 335-76$.

Tan MC, Mommaas AM, Drijfhout JW, Jordens R, Onderwater JJ, Verwoerd D, Mulder AA, van DER Heiden AN, Scheidegger D, Oomen LC. Mannose receptor-mediated uptake of antigens strongly enhances HLA class II-restricted antigen presentation by cultured dendritic cells. Eur. J. Immunol. 1997; 27: 2426-2435.

Weitzman, I.; Summerbell, R. The Dermatophytes. Clin Microbiol Rev. 1995; 8(2):240-59.

Willment JA, Brown GG. C-type lectin receptors in antifungal immunity. Trends Microbiol. 2007; 16(1):27-32.

Wilson JW, Plunkett OA, Gregersen A. Nodular granulomatous perifolliculitis due to Trichophyton rubrum. AMA Arch Derm Syphilo., 1954; 69: 258 - 277. 
Woodfolk, J. A.; Slunt, J. B.; Deuell, B.; Hayden, M. L.; Platts-Mills, T. A. E. Definition of a Trichophyton Protein Associated with Delayed Hypersensitivity in Humans - Evidence for Immediate (IgE and IgG4) and Delayed Hypersensitivity to a Single Protein. J Immunol. 1996; 156(4):1695-701.

Woodfolk JA, Sung SS, Benjamin DC, Lee JK, Platts-Mills TA. Distinct human T cell repertories mediate immediate and delayed-type hypersensitivity to the Trichophyton antigen, Tri r2. J Immunol. 2000; 165(8):4379-87.

Woodfolk JA, Platts-Mills TAE. Diversity pf the human allergen-Specific T cell repertoire associeted with distinct skin test reactions: delayed-type hypersensivity-associated major epitopes induce Th1- and Th2- Dominanted responses. J Immunol. 2001; 167(9):5412-9.

Yamasaki S, Matsumoto M, Takeuchi O, Matsuzawa T, Ishikawaa E, Sakumaa M, Tatenof H, Unoe J, Hirabayashif J, Mikamie Y, Takedag K, Akirac S, and Saito T. C-type lectin Mincle is an activating receptor for pathogenic fungus, Malassezia. PNAS. 2009; 106(6):1897-1902.

Zaia DAM, Zaia CTBV, Lichtig J. Determinação de proteínas totais via espectrofotometria: vantagens e desvantagens dos métodos existentes. Química Nova. 1998; 21(6):787-792.

Zurita J, HAY RJ The adherence of dermatophyte microconidia and arthroconidia to human keratinocytes in vitro. J Invest Dermatol. 1987; 89(5):529-34. 